\title{
Plantas trepadeiras do Parque Estadual das Fontes do Ipiranga (São Paulo, Brasil)
}

\author{
Berta Lúcia Pereira Villagra ${ }^{1,2}$ e Sergio Romaniuc Neto ${ }^{1}$
}

Recebido: 21.01.2010; aceito: 26.05.2011

\begin{abstract}
Climbing plants from Parque Estadual das Fontes do Ipiranga (São Paulo State, Brazil)). A survey of the climbing flowering plants in the tropical rain forest remnants of Parque Estadual das Fontes do Ipiranga was carried out. Collections were made from January 2006 to June 2007. One hundred, eighty seven species were found, in 109 genera, and 32 families. Identification key, illustrations and descriptions are presented. Fabaceae (21), Bignoniaceae (20) and Asteraceae (20) are the families with the highest species richness. Mikania and Passiflora are the richest genera, both with 12 species. Twiners are the most common adaptation (40.8\%) Species richness of climbing plants found in Parque Estadual das Fontes do Ipiranga is similar of those found in extensive rain tropical forested area, emphasizing the importance, for climbing plants, of the conservation of isolated forest remnants.
\end{abstract}

Key words: floristic, lianas, rain forest

RESUMO - (Plantas trepadeiras do Parque Estadual das Fontes do Ipiranga (São Paulo, Brasil)). O presente trabalho objetivou inventariar o componente de trepadeiras em fragmento de Floresta Ombrófila Densa do Parque Estadual das Fontes do Ipiranga. As coletas ocorreram entre janeiro de 2006 e junho de 2007. Foram encontradas 187 espécies, distribuídas em 109 gêneros, pertencentes a 32 famílias. Foi elaborada chave para determinação das espécies, além de ilustrações e descrições sucintas. As famílias com maior riqueza específica foram Fabaceae (21), Bignoniaceae (20) e Asteraceae (20). Os gêneros com maior riqueza em número de espécies foram Mikania e Passiflora, ambos com 12 espécies. A adaptação volúvel foi a mais frequente, ocorrendo em $40,8 \%$ das espécies. A riqueza de espécies trepadeiras encontradas na área estudada é semelhante àquela de áreas contínuas de Floresta Ombrófila Densa, ressaltando a importância e necessidade de conservação de fragmentos florestais isolados para as trepadeiras.

Palavras-chave: floresta atlântica, inventário florístico, lianas

\section{Introdução}

Nas florestas tropicais as plantas trepadeiras são um importante componente na sua fisionomia e estrutura, frequentemente apresentando alta diversidade (Gentry 1991, Engel et al. 1998, Hora \& Soares 2002).

Embora o avanço no conhecimento da composição e estrutura de floresas tenha se desenvolvido satisfatoriamente, uma lacuna nos estudos do grupo de trepadeiras pode ser percebida. O reduzido número de estudos provavelmente se deve à dificuldade de coleta associada aos problemas metodológicos, no que se refere ao conhecimento de suas comunidades.

Para a Mata Atlântica, Kim (1996) demonstrou para 361 espécies de trepadeiras, padrões de floração com picos em fevereiro e novembro, coincidindo com a estação chuvosa e $52,4 \%$ das espécies são anemocóricas, principalmente Asteraceae e Sapindaceae.

Melhem et al. (1981) apresentaram projeto da Flora Fanerogâmica do Parque Estadual das Fontes do Ipiranga, que foi concluído em 2001, resultando em 32 famílias apresentando hábito de trepadeira.

Para o município de São Paulo, entre os levantamentos florísticos que incluem as trepadeiras também podem ser destacados Garcia \& Pirani (2005), para matas nebulares da Serra do Mar e Groppo \& Pirani (2005) para mata de planalto com chaves de identificação.

Embora facilmente reconhecidas nas sinúsias da floresta, as trepadeiras ainda carecem de precisão

1. Instituto de Botânica, Caixa Postal 68041, 04045-972 São Paulo, SP, Brasil

2. Autor para correspondência: bertavillagra@gmail.com 
quanto à sua nomenclatura e definição (Plumier 1693, Palm 1827, Mohl 1827, Darwin 1867, Schenck 1892, Du Rietz 1931 apud Richards 1996, Raunkier 1934, Radford et al. 1974, Whittaker 1978, Janzen 1980, Putz 1984, Gentry 1982, 1985, Whitmore 1990, Putz \& Mooney 1991, Judd et al. 2002).

Dentre as várias denominações encontradas na literatura, seguimos a de Darwin (1867), com a sugestão da inclusão da propriedade morfológica do caule, trepadeira herbácea ou trepadeira lenhosa.

$\mathrm{O}$ presente trabalho objetivou inventariar o componente de trepadeiras fanerógamas em fragmento de Floresta Ombrófila Densa e contribuir para o conhecimento deste grupo de plantas.

\section{Material e métodos}

O Parque Estadual das Fontes do Ipiranga - PEFI (figura 1), está situado na região sul da cidade de São Paulo (233' ${ }^{\circ} \mathrm{S}$ e $46^{\circ} 37^{\prime} \mathrm{W}$ ) (Melhem et al. 1981), com área total de 549,31 ha e altitude média de $798 \mathrm{~m}$ (Bicudo et al. 2002) e a vegetação pertence ao grupo das florestas pluviais tropicais do Domínio da Mata Atlântica, e ao grupo de floresta ombrofila densa (Veloso et al. 1991).

As coletas foram realizadas no período de janeiro de 2006 a junho de 2007, com visitas semanais utilizando-se das várias trilhas, estradas e picadas, principalmente no trecho sob administração do Instituto de Botânica.

Para a amostragem florística foram consideradas trepadeiras todos os indivíduos terrícolas que utilizam suporte para sustentação, sejam lenhosos ou herbáceos, podendo apresentar adaptação de escalada volúvel, preensil, escandente ou radicante. Do ponto de vista morfológico, trepadeira herbácea é aquela que apresenta epiderme e trepadeira lenhosa é a que apresenta casca proveniente de crescimento secundário.

O material botânico foi processado conforme recomendações de Fidalgo \& Bononi (1984) e incorporado ao acervo do Herbário do Estado "Maria Eneyda P. Kauffmann Fidalgo" (SP). A identificação botânica utilizou como base revisões e monografias taxonômicas recentes, comparação com o acervo do Herbário SP e confirmação por especialistas, sempre que necessário.

Foi preparada uma chave de identificação para as espécies, com ênfase em características vegetativas. Para as descrições foi selecionado um material representativo de cada táxon e a terminologia

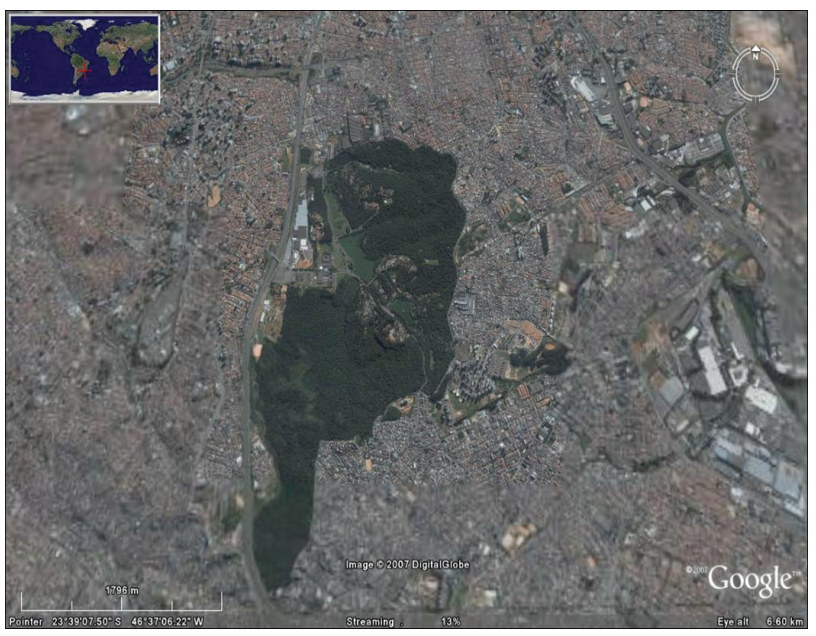

Figura 1. Localização da área de estudo, Parque Estadual das Fontes do Ipiranga, São Paulo, Brasil.

Figure 1. Location of study areas, Parque Estadual das Fontes do Ipiranga, São Paulo, Brazil.

empregada foi a de Radford et al. (1974) e Gonçalvez \& Lorenzi (2008). Para a listagem das famílias adotou-se Angiosperm Phylogeny Group II (2003) e Brummitt \& Powell (1992) para a abreviação dos nomes dos autores.

\section{Resultados e Discussão}

Foram identificados 187 táxons de trepadeiras fanerógamas, 60 provenientes de coleta feitas para o presente trabalho, distribuídos em 109 gêneros pertencentes a 32 famílias e incluídas 218 registros de exsicatas no herbário SP.

As famílias mais representativas em número de espécies são Fabaceae (21), seguida de Bignoniaceae (20), Asteraceae (20), Apocynaceae (18) e Passifloraceae (12), juntas representaram $46 \%$ do total de trepadeiras encontradas.

Os gêneros com maior número de espécies foram Mikania (Asteraceae) e Passiflora (Passifloraceae), ambos com 12 espécies, Ipomoea (Convolvulaceae) com sete espécies, Serjania (Sapindaceae) com seis espécies, Machaerium (Fabaceae) e Dioscorea (Dioscoreaceae) com cinco espécies cada. Estes seis gêneros possuem juntos $24 \%$ do total de espécies amostradas e todos eles com exceção de Dioscorea e Serjania, fazem parte das seis famílias mais ricas em espécies.

As coletas recentes permitiram que fossem acrescentadas cinco novas ocorrências de trepadeiras para o PEFI (em relação às monografias do planejamento de Melhem et al. 1981), Mendoncia sp. 
(Acanthaceae), possivelmente uma espécie nova (C. Kameyama dados não publicados), Chamissoa altissima (Amaranthaceae), Seguieria americana (Phytolaccaceae), Coccoloba arborescens (Polygonaceae) e Cissus serroniana (Vitaceae).

A adaptação volúvel está presente em 40,8\% das espécies de trepadeiras, as famílias que mais contribuem são Convolvulaceae, Asteraceae, Apocynaceae e Passifloraceae. A adaptação menos encontrada é a radicante, presente em Marcgraviaceae, Udulutsch (dados não publicados) também encontrou um maior número da adaptação volúvel (44,9\%) dentre as 49 espécies de trepadeiras lenhosas encontradas para floresta ombrófila densa no Parque Estadual Carlos Botelho.

Lima et al. (1997) também em floresta ombrófila densa da Reserva Ecológica de Macaé de Cima levantaram 144 espécies de trepadeiras, sendo 43,75\% de adaptação preensil e $43 \%$ volúvel.

O presente trabalho revelou a importância da sinúsia de trepadeiras no PEFI, que contribuiu com $17 \%$ das espécies da flora fanerogâmica planejada por Melhem et al. (1981) e 52\% das espécies estiveram presente no levantamento para Mata Atlântica (Kim 1990).
A riqueza de Bignoniaceae, Convolvulaceae e Fabaceae encontradas no PEFI indicam grandes semelhanças entre áreas de floresta ombrófila densa com áreas de floresta estacional semidecidual nos trabalhos de Udulutsch (2004), Rezende (1997) e floresta ombrófila densa em Groppo \& Pirani (2005).

A riqueza de espécies trepadeiras encontradas na área estudada é semelhante àquela de áreas contínuas de floresta ombrófila densa, ressaltando a importância e necessidade de conservação de trepadeiras em fragmentos florestais isolados. Garcia \& Pirani (2005) que estudaram mata nebulares na Serra do Mar, levantaram 56 espécies de trepadeiras, 14 em comum com o PEFI, enquanto que Groppo \& Pirani (2005) levantaram 82 espécies de trepadeiras, sendo $46 \mathrm{em}$ comum com a Mata do PEFI. Essa maior similaridade florística é devido à proximidade geográfica entre o PEFI e a Mata da Cidade Universitária “Armando de Salles Oliveira".

Segundo Mamede et al. (2007) as espécies de trepadeiras ameaçadas de extinção que ocorrem no PEFI são três: Matelea glaziovii (E. Fourn.) Morillo como vulnerável, Galactia neesii DC. como presumivelmente extinta e Cissus serroniana (Glaz.) Lombardi como vulnerável.

Chave para determinação das espécies de trepadeiras no PEFI

1. Trepadeira radicante

18.1 Marcgravia polyantha

1. Trepadeira escandente, volúvel ou preensil

2. Planta com gavinha

3. Folhas simples

4. Folhas opostas

16.2 Strychnos nigricans

4. Folhas alternas

5. Duas gavinhas na bainha foliar

6. Ramos inermes

26.4 Smilax staminea

6. Ramos armados

7. Ramos estriados, subcilíndricos; acúleos esparsos

26.3 Smilax remotinervis

7. Ramos lisos, cilíndricos; acúleos concentrados nos entrenós

8. Lâmina crasso-coriácea, castanha quando seca, $5-12 \mathrm{~cm}$ compr.

8. Lâmina papirácea; enegrecida quando seca, $14-23 \mathrm{~cm}$ compr.

26.1 Smilax elastica

5. Uma gavinha

9. Gavinha no prolongamento da raque foliar

5.16 Mutisia speciosa

9. Gavinha axilar ou oposta às folhas

10. Gavinha oposta às folhas, formando ângulo de $90^{\circ}$ 32.4 Cissus verticillata

10. Gavinha axilar

11. Ramos lenhosos

20.3 Passiflora edulis

11. Ramos herbáceos

12. Ramos angulares

13. Lâmina inteira

20.1 Passiflora alata 
13. Lâmina lobada

14. Ramos subangulares; pecíolos 2,8-3,1 cm compr. .... 20.9 Passiflora organensis

14. Ramos 5-angular; pecíolos 0,6-2,1 cm compr. 20.7 Passiflora misera

12. Ramos cilíndricos, sulcados ou lisos

15. Lâmina inteira

16. Gavinha ramificada

17. Gavinha 2-ramificada

18. Lâmina glabra

11.8 Sicydium gracile

18. Lâmina pubérula ou pubescente

19. Lâmina com 1 par de glândulas na base

19. Lâmina desprovida de glândulas

20. Pedicelo 7-9 cm compr.

11.6Fevilleapassiflora

20. Pedicelo $1-5 \mathrm{~cm}$ compr.

11.3 Cayaponia pilosa

17. Gavinha 3-ramificada

21. Lobos da lâmina oblongos

11.1 Cayaponia cabocla

21. Lobos da lâmina ovais a triangulares

22. Lâmina estrigosa; pedicelo 5-10 mm compr.

5 Echinopepon racemosus

22. Lâmina pubescente; pedicelo $1-5 \mathrm{~cm}$ compr.

11.2 Cayaponia martiana

11.1 Cayaponia cabocla

16. Gavinha simples

23. Estípula ausente

11.7 Melothria cucumis

23. Estípula presente

24. Estípula falcada 20.4 Passiflora haematostigma

24. Estípula reniforme

25. Ramos estriados; lâmina 6-11 cm compr

20.5 Passiflora jilekii

25. Ramos lisos; lâmina 3-5 cm compr

20.6 Passiflora miersii

15. Lâmina lobada

26. Gavinha simples

27. Lâmina com ocelo

20.11 Passiflora truncata

27. Lâmina desprovida de ocelo

28. Margem da lâmina inteira

29. Ramos glabros; estípula reniforme

20.10 Passiflora sidaefolia

29. Ramos hirsutos; estípula oval-lanceolada

20.12 Passiflora villosa

28. Margem crenada ou denteada

30. Ramos híspidos; estípula presente

20.8 Passiflora morifolia

30. Ramos glabros; estípula ausente

31. Nectário 1 par, crateriforme

20.2 Passiflora cincinnata

31. Nectário ausente

32. Lâminas 3-4 cm compr.; sementes amareladas

11.7 Melothria cucumis

32. Lâminas 5-18 cm compr.; sementes castanhas

11.10 Wilbrandia verticillata

26. Gavinha ramificada

33. Gavinha 5-ramificada

11.9 Sicyos polyacanthus

33. Gavinha 2-3-ramificada

34. Ramos densamente vilosos

11.4 Cayaponia villosissima

34. Ramos pubérulos, estrigosos ou pubescentes 
35. Gavinha 2-ramificada

36. Lâmina 3-5-lobada, lobo lanceolado, $8-12 \mathrm{~cm}$ compr. 11.3 Cayaponia pilosa

36. Lâmina 3-lobada, lobo ovado, 4-17 cm compr. 11.1 Cayaponia cabocla

35. Gavinha 3-ramificada

36. Lâmina 3-5-lobada, lobo lanceolado, 8-12 cm compr

11.3 Cayaponia pilosa

36. Lâmina 3-lobada, lobo ovado, 4-17 cm compr.

37. Lâmina 3-5-lobada, lobo oblongo

11.2 Cayaponia martiana

37. Lâmina 3-lobada, lobo oval a triangular

38. Lâmina 8-12 × 4-8 cm, esparso-estrigosa

11.5 Echinopepon racemosus

38. Lâmina 4-17 × 3-24 cm, pubescente

11.1 Cayaponia cabocla

3. Folhas compostas

39. Folhas opostas

40. Gavinha simples

41. Ramos achatados, fistulosos

6.18 Stizophyllum perforatum

41. Ramos cilíndricos

42. Ramos púberulos, lepidotos ou pubescentes

43. Glândula na região interpeciolar

44. Lâmina glabra

6.3 Arrabidaea chica

44. Lâmina pubescente na nervura principal

45. Lâmina oval, $2-4 \times 1,5-2 \mathrm{~cm}$.

6.4 Arrabidaea pulchella

45. Lâmina elíptica, $3,5-8,5 \times 3-5 \mathrm{~cm}$ 6.5 Arrabidaea samydoides

43. Glândula interpeciolar ausente

46. Lâmina elíptica; pecíolo 2-5,5 cm compr.; corola vermelha

6.9 Fridericia speciosa

46. Lâmina oval; pecíolo 1,5-2,5 cm compr.; corola alva

6.11 Lundia virginalis

42. Ramos glabros

47. Lâmina oval, base arredondada; corola alva

6.2 Anemopaegma prostratum

47. Lâmina elíptica, base atenuada; corola amarela 6.6 Callichlamys latifolia

40. Gavinha 3-fida ou mais ramificada

48. Gavinha uncinada ou com disco aderente

49. Gavinha com disco aderente

6.10 Haplolophium bracteatum

49. Gavinha uncinada

50. Ramos pubérulos; folíolo até $6,5 \mathrm{~cm}$ compr.

6.8 Dolichandra unguis-cati

50. Ramos glabros; folíolo com mais de $6,5 \mathrm{~cm}$ compr.

51. Lâmina elíptica a oval, base assimétrica; corola amarela

6.7 Dolichandra quadrivalvis

51. Lâmina oblonga, base simétrica; corola rósea

6.19 Tanaecium pyramidatum

48. Gavinha desprovida de unha ou disco

52. Ramos angulosos

53. Ramos 4-angular; folhas 2-ternadas

6.16 Pleonotoma tetraquetra

53. Ramos 6-8-angular; folhas 2-3 folioladas

54. Lâmina 4,5-6,5 cm compr.; corola alaranjada a amarela ...... 6.17 Pyrostegia venusta

54. Lâmina 7-11 cm compr.; corola alva 
55. Pecíolo 3-8 cm compr.; peciólulo 2-4 cm compr.

6.1 Amphilophium crucigerum

55. Pecíolo 1,5-2,5 cm compr.; peciólulo 0,8-1,2 cm compr.

6.15 Pithecoctenium dolichoides

52. Ramos cilíndricos

56. Ramos glabros, descamantes ....

6.14 Parabignonia unguiculata

56. Ramos pubérulos, não descamantes

57. Lâmina pubescente; corola alva

6.20 Tynanthus elegans

57. Lâmina glabra, pubérula somente na nervura; corola rósea ou lilás

58. Lâmina 3-5 × 1-3 cm compr.; pecíolo 1,5-2 cm compr.

6.13 Mansoa schwackei

58. Lâmina 5-10 × 3-6 cm compr.; pecíolo 2,5-4 cm compr.

6.12 Mansoa difficilis

39. Folhas alternas

59. Uma gavinha

60. Gavinha simples ou bífida

32.3 Cissus sulcicaulis

60. Gavinha 4 ou mais ramificada

61. Folhas 5-folioladas

32.1 Cissus paullinifolia

61. Folhas 3-pinadas

32.2 Cissus serroniana

59. Duas gavinhas

62. Gavinha alterna à folha; fruto legume

15.16 Phanera angulosa

62. Gavinha na base da inflorescência; fruto cápsula ou esquizocarpo

63. Caule com corpo lenhoso simples

64. Cápsula; semente arilada

65. Folhas pinadas ternadas; fruto cápsula trígona a 3-alada

25.2 Paullinia micrantha

65. Folhas pinadas em jugas; fruto cápsula globosa

66. Folhas 3-jugas; folíolo de margem inteira

25.1 Paullinia carpopoda

66. Folhas 2-jugas; folíolo de margem serreada

25.3 Paullinia seminuda

64. Esquizocarpo; semente sem arilo

67. Ramos angulosos; folíolo séssil a subséssil, margem inteira

25.6 Serjania gracilis

67. Ramos lisos; folíolo peciolulado, margem serreada

25.9 Serjania reticulata

63. Caule com corpo lenhoso composto por um cordão central e 3-8 periféricos

68. Folhas 3-folioladas

25.10 Thinouia ventricosa

68. Folhas 2-ternadas ou pinadas

69. Corpo lenhoso composto por 1 cordão central e 4-6 periféricos;

foliólulos com domácias em tufo nas axilas das nervuras secundárias

25.4 Serjania caracasana

69. Corpo lenhoso composto de outra forma; folíolo sem domácias

70. Corpo lenhoso composto por 1 cordão central e 8 periféricos

25.8 Serjania multiflora

70. Corpo lenhoso composto por 1 cordão central e 3 periféricos

71. Folíolo terminal, margem inteira

25.7 Serjania lethalis

71. Folíolo terminal, margem serreado-dentada

25.5 Serjania communis

2. Planta sem gavinha (escandente ou volúvel)

72. Trepadeira que utiliza ramo ou pecíolo como estratégia de escalada (volúvel)

73. Folhas compostas

74. Folhas opostas

29.1 Valeriana scandens

74. Folhas alternas

75. Folhas 1-foliolada

15.7 Galactia decumbens 
75. Folhas 3-folioladas

76. Ramos lenhosos

15.6 Dioclea rufescens

76. Ramos herbáceos

77. Folíolo central elíptico, laterais assimétricos, margem serrilhada

14.1 Dalechampia triphylla

77. Folíolo oval, linear-lanceolado, rombóide, oblongo-lanceolado, margem inteira

78. Folíolo rombóide ou linear-lanceolado

79. Folíolo linear-lanceolado, 4,5-6 × 1,3-1,5 cm

15.1 Camptosema scarlatinum

79. Folíolo rombóide, $9-10 \times 5,5-7 \mathrm{~cm}$ 15.20 Vigna candida

78. Folíolo oval, elíptico ou oblongo-lanceolado

80. Ramos pubescentes

81. Lâmina 4,5-6 cm larg.; folíolo elíptico

15.3 Centrosema grandiflorum

81. Lâmina 1,5-4 cm larg.; folíolo oval ou oblongo-lanceolado

82. Lâmina eglandulosa, face adaxial pubérula 15.2 Canavalia picta

82. Lâmina não glandulosa, face adaxial esbranquiçada em torno da nervura principal 15.5 Desmodium uncinatum

80. Ramos hirsutos a glabros

83. Apículos presentes nos folíolos

84. Ápice do folíolo agudo, base cordada

15.8 Galactia neesii

84. Ápice e base do folíolo obtuso 15.21 Vigna luteola

83. Apículos ausentes

85. Folíolo oval

15.17 Rhynchosia phaseoloides

85. Folíolo oval, lobado 15.14 Macroptilium erythroloma

73. Folhas simples

86. Folhas alternas

87. Venação actinódroma, acródoma ou palinactinódroma

88. Pecíolo articulado

89. Ramos alados

90. Lâmina elíptica-oval, $12-14 \times 5,5-8,5 \mathrm{~cm}$.

13.2 Dioscorea marginata

90. Lâmina oblonga-lanceolada, 6,5-8,5 × 1,5-2,5 cm

13.4 Dioscorea olfersiana

89. Ramos não alados

91. Lâmina glabra, coriácea

13.3 Dioscorea multiflora

91. Lâmina pubescente a híspida, membranácea

92. Lâmina 7-15 × 7-17 cm

13.1 Dioscorea dodecaneura

92. Lâmina 5-8 × 4-6 cm 13.5 Dioscorea subhastata

88. Pecíolo simples

93. Pseudoestípula presente

4.1 Aristolochia galeata

93. Pseudoestípula ausente

94. Ramos glabros

95. Lâmina lobada

96. Lâmina 7-9 × 6-8 cm

10.2 Ipomoea alba

96. Lâmina 3-4 × 1-1,7 cm 10.4 Ipomoea cairica

95. Lâmina inteira

97. Planta aromática, pecíolo retorcido

27.1 Solanum inodorum

97. Planta não aromática, pecíolo não retorcido

98. Lâmina pubescente

19.2 Cissampelos andromorpha

98. Lâmina glabra

99. Venação 3-nervada

19.1 Abuta selloana 
99. Venação 5-7 nervada

100. Ápice da lâmina caudado

19.3 Disciphania modesta

100. Ápice da lâmina acuminado a apiculado

19.5 Odontocarya acuparata

94. Ramos tomentosos, hirsutos ou pubescentes

101. Planta lenhosa

19.4 Hyperbaena domingensis

101. Planta herbácea

102. Lâmina inteira

103. Lâmina sagitado-oblonga

10.1 Convolvulus crenatifolius

103. Lâmina oval a cordada ou elíptica a lanceolada

104. Lâmina $5-11,5 \times 1-4 \mathrm{~cm}$ 4.2 Aristolochia melastoma

104. Lâmina 5-6,5 × 4,5-6,5 cm

105. Ramos hirsutos, corola purpúrea, azul, rósea ou branca 10.6 Ipomoea purpurea

105. Ramos pubescentes, corola purpúrea com fauce alva

10.5 Ipomoea indica

102. Lâmina lobada

106. Lâmina 5-7-lobada

10.10 Merremia macrocalyx

106. Lâmina 3-lobada

107. Lâmina deltóide

10.3 Ipomoea aristolochiaefolia

107. Lâmina cordada

108. Lâmina 3-4 cm compr.

10.8 Ipomoea triloba

108. Lâmina 5-6 cm compr.

109. Ramos pubescentes amarelo-

-translúcidos 10.5 Ipomoea indica

109. Ramos hirsutos 10.6 Ipomoea purpurea

87. Venação craspedródoma ou camptódroma

110. Planta lenhosa

111. Ramos glabros; pecíolo 0,3-0,6 cm compr.

7.1 Tournefortia breviflora

111. Ramos tomentosos; pecíolo 0,8-1,2 cm compr. 7.2 Tournefortia villosa

110. Planta herbácea

112. Lâmina lobada

10.10 Merremia macrocalyx

112. Lâmina inteira

113. Ramos com indumento ferrugíneo 10.9 Jacquemontia ferruginea

113. Ramos com indumento esbranquiçado ou translúcido

114. Base da lâmina obtusa

10.11 Odonellia eriocephala

114. Base da lâmina cordada 10.7 Ipomoea saopaulista

86. Folhas opostas ou verticiladas

115. Látex presente

116. Folhas verticiladas

3.2 Condylocarpon isthmicum

116. Folhas opostas

117. Ramos glabros

118. Folhas com coléteres

119. Base da lâmina obtusa; sépala oval-triangular

3.8 Gonioanthela axillaris

119. Base da lâmina cordiforme; sépala triangular-lanceolada

3.13 Oxypetalum pachyglossum

118. Folhas sem coléteres

120. Látex translúcido

3.16 Prestonia coalita

120. Látex branco 
121. Lâmina elíptico-lanceolada, 1,5-2,5 cm larg.

3.6 Forsteronia australis

121. Lâmina oblongo-elíptica, 3,5-4,5 cm larg.

3.17 Secondatia densiflora

117. Ramos pubescentes, tomentosos, vilosos, velutinos ou híspidos

122. Folhas sem coléteres

123. Lâmina elíptica a oblonga

3.7 Forsteronia rufa

123. Lâmina oval, base peltada 3.15 Peltastes peltatus

122. Folhas com coléteres

124. Lâmina linear

125. Lâmina 2-4,6 cm compr.

3.5 Ditassa tomentosa

125. Lâmina 0,6-1 cm compr. 3.18 Tassadia subulata

124. Lâmina elíptica, oblonga, oval, lanceolada

126. Ramos híspidos

3.4 Ditassa hispida

126. Ramos pubescentes, tomentosos, velutinos ou vilosos

127. Lâmina acima de $4,5 \mathrm{~cm}$ larg. 3.9 Matelea glaziovii

127. Lâmina 1-4 cm larg.

128. Lâmina lanceolada a elíptica, $1,5-5,5 \times 0,5-2,5 \mathrm{~cm}$

129. Lâmina pubescente

3.3 Ditassa burchelli var. vestita

129. Lâmina glabra

130. Ramos esparsamente pubescentes; inflorescência 3-6-flora 3.1 Blepharodon pictum

130. Ramos unilateralmente pubescentes; inflorescência 7-14 -flora 3.10 Orthosia urceolata

128. Lâmina oval, oboval ou oblongotriangular, 3-13 × 1-4 cm

131. Base da lâmina cordiforme a sagitada, margem frequentemente revoluta 3.14 Oxypetalum wightianum

131. Base da lâmina cordiforme ou arredondada, margem lisa 132. Ramos vilosos, sépalas triangularlanceoladas 3.12 Oxypetalum insigne

132. Ramos tomentosos, sépalas linearlanceoladas

115. Látex ausente 3.11 Oxypetalum appendiculatum

133. Nectários glandulares presente na folha

134. Lâmina até $6,5 \mathrm{~cm}$ compr.

135. Lâmina glabra; eglandulosa, inflorescência em racemos

17.6 Mascagnia sepium

135. Lâmina pubescente, 1-2 pares de glândulas no pecíolo; inflorescência em panículas 17.8 Tetrapterys phlomoides

134. Lâmina acima de $6,5 \mathrm{~cm}$ compr.

136. Lâmina com glândulas em pontuações negras próxima à margem 17.4 Heteropterys intermedia

136. Lâmina com glândula cupuliforme 
137. Ramos glabros

138. Lâmina 11,5-23 × 4,5-9 cm; glândulas na nervura secundaria 17.3 Heteropterys chrysophylla

138. Lâmina 7-12,5 × 1,5-4,5 cm, glândulasna base do limbo 17.7 Tetrapterys mucronata

137. Ramos pubérulos a pubescentes

139. Lâmina oboval 17.5 Hiraea fagifolia

139. Lâmina oval a oval-arredondada

140. Face adaxial hirsuta, face abaxial castanho-velutino 17.2 Banisteriopsis campestris

140. Face adaxial glabrescente, abaxial velutina...

17.1 Banisteriopsis adenopoda

133. Nectários foliares ausentes

141. Estípula interpeciolar, persistente

142. Lâmina 5-6,5 cm compr.; corola vermelha

24.3 Manettia gracilis

142. Lâmina 7,5-10 cm compr.; corola vermelha e amarela

24.4 Manettia luteo-rubra

141. Estípula ausente ou rudimentar

143. Ramos lenhosos

144. Ramos glabros; folhas glabras, cartáceas

145. Lâmina de margem crenulada ou serreada

146. Lâmina oval, base obtusa; pecíolo canaliculado

9.1 Hippocratea volubilis

146. Lâmina elíptica, base cuneada; pecíolo não canaliculado 9.3 Pristimera celastroides

145. Lâmina de margem inteira

147. Peciolo acima de $1 \mathrm{~cm}$ compr.

148. Lâmina 8-13 × 6-14 cm, oval a triangular, base hastada 5.7 Mikania glomerata

148. Lâmina 7,5-11,5 × 1,8-3,4 cm, eliptica, base cuneada 9.5 Tontelea miersii

147. Pecíolo até $1 \mathrm{~cm}$ compr.

149. Resina vermelha; inflorescência em fascículo; disco nectarífero piriforme; corola creme-esverdeada 9.4 Salacia elliptica

149. Resina ausente; inflorescência em panícula; disco nectarífero tubular; corola amarela . 9.2 Peritassa hatschbachii

144. Ramos pubérulos, vilosos, pubescentes; folhas pubescentes, membranáceas 150. Margem da lâmina denteada 5.10 Mikania lanuginosa

150. Margem da lâmina de margem inteira

151. Entrenó de 2-5 cm compr.; lâmina lanceolada 5.11 Mikania lasiandrae

151. Entrenó acima de 7 cm compr.; lâmina oval 5.8 Mikania hirsutissima

143. Ramos herbáceos 152. Venação eucamptódroma 
153. Bráctea lanceolada, vermelha

1.2 Mendoncia velloziana

153. Bráctea oval-elíptica ou triangular a oval, verde

154. Bráctea internamente pubescente; corola alva ....

1.1 Mendoncia puberula

154. Bráctea internamente glabra; corola vermelha .... Mendoncia sp.

152. Venação actinódroma, acródoma ou broquidródoma

155. Lâmina cordiforme, margem crenada a denteada

5.12 Mikania micrantha

155. Lâmina oval, deltóide ou lanceolada, margem inteira

156. Pecíolo acima de $3 \mathrm{~cm}$ compr.

157. Venação actinódroma

5.5 Mikania campanulata

157. Venação acródroma

5.14 Mikania rufescens

156. Pecíolo até $3 \mathrm{~cm}$ compr.

158. Pecíolo acima de $1,5 \mathrm{~cm}$ compr.

158. Pecíolo até $1,5 \mathrm{~cm}$ compr.

159. Venação acródroma

5.9 Mikania laevigata

159. Venação broquidródoma

5.15 Mikania trinervis

160. Entrenó 1,5-4,5 cm compr

5.4 Mikania buddleiaefolia

160. Entrenó 5-18 cm compr.

5.6 Mikania chlorolepis

72. Trepadeiras que não possuem estrutura adaptativa para fixação, sem mecanismos de aderência, escandentes 161. Folhas compostas

162. Folhas 2 -folioladas (menos frequentemente inteira)

15.16 Phanera angulosa

162. Folhas 5 ou mais folioladas

163. Folhas bipinadas

164. Espinho reto

15.15 Mimosa bimucronata

164. Espinho recurvo

165. Folhas 20-26 cm compr., pina com 10-25 foliólulos

165. Folhas 14-18 cm compr., pina com 40-60 foliólulos

15.18 Senegalia grandistipula

15.19 Senegalia martii

163. Folhas pinadas

166. Folhas 5-9 folioladas

167. Venação eucamptódroma

15.4 Dalbergia frutescens

167. Venação broquidródoma ou craspedródoma

168. Ramos glabros

15.10 Machaerium lanceolatum

168. Ramos hirsutos a pubérulos

169. Indumento hirsuto amarelado

15.11 Machaerium oblongifolium

169. Indumento ferrugíneo 15.12 Machaerium triste

166. Folhas 10-35 folioladas

170. Folíolo 4,5-5,5 cm compr., pubescente

15.9 Machaerium cantarellianum

170. Folíolo 1-2 cm compr., glabro

15.13 Machaerium uncinatum

161. Folhas simples

171. Folhas alternas

172. Caule armado

173. Espinho disperso no caule 
174. Estípula modificada em acúleo uncinado; venação broquidódroma

21.1 Seguieria americana

174. Espinho axilares curvo; venação eucamptódroma

5.3 Dasyphyllum brasiliense

173. Espinho em aréola

175. Ramos com aréolas de espinhos retos; lâmina 8-11 cm compr.

8.2 Pereskia grandifolia

175. Ramos com aréolas de espinhos curvos; lâmina 3-5 cm compr.

8.1 Pereskia aculeata

172. Caule inerme

176. Casca descamante, vermelha

177. Lâmina membranácea, margem serreada

12.1 Davilla rugosa

177. Lâmina coriácea, margem inteira 12.2 Doliocarpus glomeratus

176. Casca não descamante, castanha

178. Ócrea presente

23.1 Coccoloba arborescens

178. Ócrea ausente

179. Nectário presente no pedicelo

18.2 Schwartzia brasiliensis

179. Néctário ausente

180. Venação broquidódroma

181. Pecíolo com glândulas laterais na base

22.2 Diclidanthera laurifolia

181. Pecíolo desprovido de glândulas

182. Ramo quadrangular 5.19 Piptocarpha quadrangularis

182. Ramo cilíndrico

183. Lâmina glabra 31.1 Anchietea pyrifolia

183. Lâmina pubérula, tomentosa ou pubescente

184. Lâmina oblonga-lanceolada; pecíolo $5-10 \mathrm{~cm}$ compr.

Piptocarpha oblonga

184. Lâmina elíptica; pecíolo 0,2-1 cm compr.

185. Lâmina de face abaxial lepidoto tomentosa, glanduloso pontuada, margem inteira

5.18 Piptocarpha pyrifolia

185. Lâmina de face abaxial alvo-tomentosa, margem serreada .... 5.2 Cyrtocymura scorpioides

180. Venação eucamptódroma

186. Lâmina acima de $6 \mathrm{~cm}$ compr.

22.1 Bredemeyera autranii

186. Lâmina até $6 \mathrm{~cm}$ compr.

187. Lâmina oval ou lanceolada; flor alva, esverdeada a amarela 22.3 Polygala lancifolia

187. Lâmina elíptica; flor rósea a purpúrea

171. Folhas opostas 22.4 Securidaca lanceolata 188. Planta armada 16.1 Strychnos brasiliensis

188. Planta inerme

189. Estípula interpeciolar presente 
190. Estípula interpeciolar caduca

191. Ramos esbranquiçados; lâmina acima de $8 \mathrm{~cm}$ compr.

28.1 Trigonia nivea

191. Ramos esverdeados; lâmina até $7 \mathrm{~cm}$ compr. ....... 28.2 Trigonia paniculata

190. Estípula interpeciolar persistente

192. Estípula 6-10-laciniada

24.2 Emmeorhiza umbellata

192. Estípula 2-laciniada

24.1 Chiococca alba

189. Estípula interpeciolar ausente

193. Ramos hexagonais

5.1 Calea pinnatifida

193. Ramos cilíndricos

194. Ramos glabros

5.13 Mikania oblongifolia

194. Ramos pubescentes, pubérulos, hirsutos ou tomentosos

195. Lâmina de margem serrilhada ou denteada

196. Lâmina glabra

30.1 Petrea volubilis

196. Lâmina alvo-tomentosa

5.20 Trixis antimenorrhoea

195. Lâmina de margem inteira

197. Lâmina 5,5-9,5 cm compr., margem revoluta

2.2 Hebanthe paniculata

197. Lâmina 13-17 cm compr., margem ondulada

2.1 Chamissoa altissima

\section{ACANTHACEAE}

1.1. Mendoncia puberula Mart., Nov. Gen. sp. pl. 3: 24.1829.

Trepadeira herbácea, volúvel; látex ausente. Ramos pubérulos. Folhas simples, opostas; lâmina 0,9-1,6 × 0,7-1,7 cm, oblonga-elíptica; ápice mucronado; base obtusa; face adaxial glabrescente; face abaxial hirsuta; venação eucamptódroma; estípulas ausentes; nectários ausentes. Inflorescências em racemos axilares; flores 1-2 por axila; brácteas 2, oval-elípticas, verdes, pubescentes em ambas as faces; corola 1,8-3 cm compr., alva, infundibuliforme, lobos desiguais. Drupas 1,4-1,7 × 0,9-1,1 cm, castanhas ou pretas.

Material selecionado: BRASIL. São Paulo: São Paulo, Parque Estadual das Fontes do Ipiranga, 17-XIII-1980, F. Barros 595 (SP).

Ilustração em Buzato \& Vitta (2005).

1.2. Mendoncia velloziana Mart., Nov. Gen. sp. pl. 3: 33.1829.

Trepadeira herbácea, volúvel; látex ausente. Ramos jovens pubescentes, tornando-se pubérulos. Folhas simples, opostas; lâmina 5-8 × 2-6 cm, oval-elíptica; ápice acuminado; base obtusa; face adaxial estrigosa; face abaxial tomentosa-velutina; venação eucamptódroma; estípulas ausentes; nectários ausentes. Inflorescências em racemos axilares; flores 1-2 por axila; brácteas 2, lanceoladas, vermelhas, glabras internamente, tomentoso-velutinas externamente; corola 2,5-3,9 cm compr., vermelha, tubulosa, tubo constricto no terço inferior. Drupas 1,4-1,7 × 1,3-1,5 cm compr., pretas.

Material selecionado: BRASIL. São PAUlo: São Paulo, Parque Estadual das Fontes do Ipiranga, 9-III-1978, M. Kirizawa 183 (SP).

Ilustração em Buzato \& Vitta (2005).

\subsection{Mendoncia sp.}

Figura 2

Trepadeira herbácea, volúvel; látex ausente. Ramos jovens pubescentes, tornando-se pubérulos. Folhas simples, opostas; lâmina 5,5-7,5 × 1,5-4 cm, oval-elíptica; ápice acuminado a cuspidado; base obtusa ou aguda; face adaxial estrigosa; face abaxial tomentoso-velutina; venação eucamptódroma; estípulas ausentes; nectários ausentes. Inflorescências em racemos axilares; flores 1-3 por axila; brácteas 2, triangulares a ovais, verdes, internamente glabras, 
externamente tomentoso-velutinas; corola $3-4 \mathrm{~cm}$ compr., vermelha, tubulosa. Drupas 1,3-2 × 0,7-1 cm, violáceas.

Observações: Mendoncia sp. é próxima de M. velloziana Mart., segundo Buzato \& Vitta (2005) as diferenças na forma e coloração das brácteas são suficientes para considerá-las como espécies distintas. Trata-se de espécie nova para a ciência segundo C. Kameyama (dados não publicados).

Material selecionado: BRASIL. SÃo PAULO: São Paulo, Parque Estadual das Fontes do Ipiranga, 7-I-1969, T. Sendulsky 810 (SP); 27-X-2005, B.L.P. Villagra 46 (SP); 18-XII-2006, B.L.P. Villagra 158 (SP).

\section{AMARANTHACEAE}

2.1. Chamissoa altissima (Jacq.) Kunth in Kunth, Humb. \& Bonpl., Nov. gen. sp. 2(7): 197, t. 125.1818 .

Trepadeira lenhosa, escandente. Ramos cilíndricos, hirsutos, inermes, estriados. Folhas simples, opostas; inteira; lâmina 13-17 × 2-3 cm, lanceolada; ápice acuminado; margem levemente ondulada; base atenuada; nervura central pubérula na face abaxial; venação eucamptódroma; estípulas ausentes; pecíolo 0,5-1 cm compr., hirsuto. Inflorescências em panículas, terminais ou axilares, $15-40 \mathrm{~cm}$ compr.; flores alvas, cremes ou vináceas. Cápsulas subglobosas, emarginadas no ápice. Sementes com arilo desenvolvido.

Observações: ocorrência nova para o PEFI. Difere de Hebanthe paniculata pelo tamanho das folhas, além de apresentar denso indumento hirsuto com tricomas de odor fétido quando macerados.

Material selecionado: BRASIL. São PAUlo: São José do Rio Pardo, VII-1992, S. Romaniuc Neto et al. 1068 (SP); São Paulo, Parque Estadual das Fontes do Ipiranga, 12-VII-2007, B.L.P. Villagra s.n. (SP).

\subsection{Hebanthe paniculata Mart., Beitr. Amarantac.}

96. 1825.

Trepadeira lenhosa, escandente. Ramos cilíndricos, inermes, pubérulos, estriados, intumescidos nos nós. Folhas simples, opostas, inteiras; lâmina 5,5-9,5 × 1,3-2,4 cm, ovada; ápice acuminado; margem revoluta; base atenuada; nervura central pubérula na face abaxial; venação eucamptódroma; estípulas ausentes; pecíolo 1-1,5 compr., canaliculado, glabro. Inflorescências em panículas, terminais e axilares, $15-32 \times 10-22 \mathrm{~cm}$; flores alvo-amareladas. Cápsulas monospérmicas, inclusas nas sépalas. Sementes achatadas.

Material selecionado: BRASIL. São PaUlo: São Paulo, Parque Estadual das Fontes do Ipiranga, 23-VII-1973, J.S. Silva 231 (SP).

\section{APOCYNACEAE}

\subsection{Blepharodon pictum (Vahl) W.D. Stevens, Novon} 10(3): 242. 2000.

Trepadeira herbácea, volúvel; látex branco. Ramos esparsamente pubescentes. Folhas simples, opostas; lâmina 4,5-5,5 × 1,5-2,3 cm, elípticas a oblongas, glabra; ápice acuminado; margem inteira; base obtusa; 2-3 coléteres na base da nervura principal; venação eucamptódroma. Inflorescências em cimeiras, terminais, 3-6 flores; sépalas ovais, glabras; corola alva, creme-esverdeada, subcampanulada; segmentos da corona cimbiformes ou cuculados, alvos ou cremes. Folículos fusiformes. Sementes verrucosas.

Material selecionado: BRASIL. São Paulo: São Paulo, Horto Botânico, 30-X-1901, A. Hamar s.n. (SP15783)

Ilustração em Fontella-Pereira (2005).

\subsection{Condylocarpon isthmicum (Vell.) A. DC., Prodr.} 8: 381.1844.

Trepadeira lenhosa, volúvel; látex branco. Ramos glabros a pubescentes, verrucosos. Folhas simples, verticiladas, 3 por nó; lâmina 5,5-8,5 × 2-4 cm, elíptica; ápice agudo; margem inteira; base atenuada; nervuras da face abaxial pubescentes; venação broquidódroma. Inflorescências em tirsos, axilares; brácteas inconspícuas; flores amarelas; sépalas 5; corola hipocrateriforme, tubo ca. $2 \mathrm{~mm}$ compr. Mericarpos indeiscentes 2, 8-16(-25) cm compr. Sementes $1 \mathrm{~cm}$ diâm., fusiformes.

Material selecionado: BRASIL. São Paulo: São Paulo, Parque Estadual das Fontes do Ipiranga, 5-XI-1931, F.C. Hoehne s.n. (SP28439).

Ilustração em Kinoshita (2005). 
3.3. Ditassa burchelli var. vestita (Malme) Fontella, Bradea 5(49): 478. 1991.

Trepadeira herbácea, volúvel; látex branco. Ramos pubescentes. Folhas simples, opostas; lâmina 2,5-4,5 × 0,5-1,5 cm, lanceolada, pubescente; ápice acuminado; margem levemente discolor; base cuneada; 2-3 coléteres na base da nervura principal; venação eucamptódroma. Inflorescências em cimeiras, 4-8 flores; sépalas ovais, pubescentes externamente; corola alva, linear-lanceolada, margem revoluta, com um tufo de tricomas longos no ápice. Folículos fusiformes, 2-3 cm compr. Sementes verrucosas.

Material selecionado: BRASIL. São PAULO: São Paulo, Parque Estadual das Fontes do Ipiranga, 26-II-1932, F.C. Hoehne s.n. (SP28827).

Ilustração em Fontella-Pereira(2005).

\subsection{Ditassa hispida (Vell.) Fontella, Bradea 3(2):}

\section{1979.}

Trepadeira herbácea, volúvel; látex branco. Ramos híspidos. Folhas simples, opostas; lâmina 3,2-5 × 1-2,4 cm, oval-lanceolada, híspido-tomentosa em ambas as faces; ápice acuminado; margem revoluta; base obtusa; 2-3 coléteres na base da nervura principal; venação eucamptódroma. Inflorescências em cimeiras umbeliformes, 4-16 flores; sépalas oval-lanceoladas, hirsutas externamente; corola alva, oblonga, papilosa internamente. Folículos fusiformes, 1-2 cm compr. Sementes verrucosas.

Material selecionado: BRASIL. São PAUlo: São Paulo, Parque Estadual das Fontes do Ipiranga, 18-II-1934, O. Handro s.n. (SP74163).

Ilustração em Fontella-Pereira (2005).

3.5. Ditassa tomentosa (Decne.) Fontella, Bol. Mus. Bot. Munic. 39: 1. 1979.

\section{Figura 3}

Trepadeira herbácea, volúvel; látex branco. Ramos tomentosos. Folhas simples, opostas; lâmina 2,0-4,6 × 0,8-1,6 cm, linear, hirsuto-tomentosa; ápice mucronado; margem revoluta; base cuneada; 2-3 coléteres na base da nervura principal; venação eucamptódroma. Inflorescências em cimeiras, 3-9 flores, subsésseis; sépalas lanceoladas, pubescentes; corola creme a alvo-esverdeada, subcampanulada, internamente pubescente, externamente glabra; corona
2-3 denticulada no ápice. Folículos fusiformes, 5-6 cm compr., velutinos. Sementes comosas.

Material selecionado: BRASIL. São PAUlo: São Paulo, Parque Estadual das Fontes do Ipiranga, 12-IV-2006, B.L.P.Villagra 83 (SP).

Ilustração em Fontella-Pereira (2005).

3.6. Forsteronia australis Müll. Arg. in Mart., Fl. bras. 6(1): 103. 1860.

Trepadeira lenhosa, escandente; látex branco. Ramos glabros, estriados e lenticelados. Folhas simples, opostas; lâmina 5-7,5 × 1,5-2,5 cm, elíptico-lanceoladas, glabras; ápice acuminado; margem inteira; base aguda; coléteres ausentes; venação broquidódroma; pecíolo 4-6 mm compr. Inflorescências em tirsos, terminais, multifloras; flores alvas; cálice profundamente 5-partido; corola tubulosa, tubo ca. $3 \mathrm{~mm}$ compr. Folículo 2, 30-35 × 0,1-0,4 cm, cilíndrico. Sementes 7,5-11 × 1-2 mm, comosas.

Material selecionado: BRASIL. São PaUlo: São Paulo, Jardim Botânico de São Paulo, 16-XII-1931, Hoehne s.n. (SP28596).

\subsection{Forsteronia rufa Müll. Arg. in Mart., Fl. bras.} 6(1): 100. 1860.

Trepadeira lenhosa, volúvel; látex branco. Ramos tomentosos, indumento ferrugíneo. Folhas simples, opostas; lâmina 4,5-7 × 2,5-4 cm, elíptica a oblonga; ápice agudo a acuminado; margem inteira; base arredondada; face adaxial pubescente, principalmente nas nervuras; face abaxial pilosa, indumento ferrugíneo; coléteres ausentes; venação broquidódroma; pecíolo 3-4 mm compr., tomentoso. Inflorescências em tirsos, terminais; flores alvo-esverdeadas ou cremes; cálice profundamente 5-partido; corola tubulosa, tubo ca. $2 \mathrm{~mm}$ compr. Folículo 2, 23-26 × 0,4-0,5 cm, subcilíndrico. Sementes 8-10 $\times 2 \mathrm{~mm}$, plumosas.

Material selecionado: BRASIL. São Paulo: São Paulo, Parque Estadual das Fontes do Ipiranga, 11-XII-2006, B.L.P. Villagra 142 (SP).

Ilustração em Kinoshita (2005).

3.8. Gonioanthela axillaris (Vell.) Fontella \& E.A. Schwarz, Bol. Mus. Bot. Munic. 50: 6. 1981.

Trepadeira herbácea, volúvel; látex branco. Ramos estriados, glabros. Folhas simples, opostas; 
lâmina 3,2-7 × 1-3,4 cm, oval, elíptica a oblonga, glabra, discolor; ápice acuminado; margem inteira; base obtusa; 2-3 coléteres na base da nervura principal; venação camptódroma; nervuras secundárias inconspícuas em ambas as faces; pecíolo 0,9-1,5 cm compr., glabro. Inflorescências em cimeiras, axilares, 8-12 flores; sépalas ovais-triangulares, margens ciliadas; corola creme-esverdeada, 2-4 mm. compr. Folículos fusiformes, 7-9,5 cm compr., glabros. Sementes comosas e verrucosas.

Material selecionado: BRASIL. São Paulo: São Paulo, Parque Estadual das Fontes do Ipiranga, 27-XI-1931, F.C. Hoehne s.n. (SP28534).

Ilustração em Fontella-Pereira (2005).

\subsection{Matelea glaziovii (E. Fourn.) Morillo, Ernstia} 24: 36. 1984.

Trepadeira herbácea, volúvel; látex branco. Ramos velutinos. Folhas simples, opostas; lâmina 6,5-18,5 × 4,5-11,5 cm, elíptica ou oval, velutina; ápice acuminado; margem levemente revoluta; base cordiforme; 2-3 coléteres na base da nervura principal; venação eucamptódroma. Inflorescências em corimbos, 3-10 flores; sépalas linear-lanceoladas, áureo-vilosas externamente; corola amarela-esverdeada, lobos internamente verrucosos na base, segmentos da corona unidos entre si, tão altos quanto o ginostégio. Folículos costados ou alados. Sementes comosas e verrucosas.

Material selecionado: BRASIL. São Paulo: São Paulo: Parque Estadual das Fontes do Ipiranga, 10-I-1968, R. Faria s.n. (SP113829).

Ilustração em Fontella-Pereira (2005).

3.10. Orthosia urceolata E. Fourn. in Mart., Fl. bras. 6(4): 222. 1885.

Trepadeira herbácea, volúvel; látex branco. Ramos unilateralmente pubescentes. Folhas simples, opostas; lâmina 1,8-5,1 × 0,6-2,1 cm, lanceolada a elíptica; glabra; ápice acuminado; margem inteira; base obtusa ou aguda; 2-3 coléteres na base da nervura principal; venação eucamptódroma. Inflorescências em cimeiras, axilares, 7-14 flores; sépalas ovais, glabras; corola alva a esverdeada, urceolada, tubo 1,6-1,8 mm compr., glabro; segmentos da corona tridenteados, unidos entre si, lobo mediano lanceolado, ultrapassando as anteras. Folículos fusiformes, delgados, $3-5 \mathrm{~cm}$ compr., pubérulo. Sementes comosas e verrucosas.
Material selecionado: BRASIL. São Paulo: São Paulo, Reserva Biológica, Parque Estadual das Fontes do Ipiranga, 1-VII-1978, H. Makino \& D.A. De Grande 137 (SP).

Ilustração em Fontella-Pereira (2005).

\subsection{Oxypetalum appendiculatum Mart., Nov. Gen.} sp. pl. 1: 48, t. 30. 1824.

Trepadeira herbácea, volúvel; látex branco. Ramos tomentosos. Folhas simples, opostas; lâmina 3-13 × 2-4 cm, oblonga, oval, pubescente; ápice acuminado; margem levemente revoluta; base cordiforme; 2-5(7) coléteres na base da face adaxial; venação eucamptódroma. Inflorescências em corimbos, 3-4 flores; sépalas linear-lanceoladas, pubescentes externamente; corola verde-amarelada, lobos pubescentes externamente, internamente glabros, levemente verrucosos, segmentos da corona da mesma altura que as anteras. Folículos ovais ou fusiformes, 6-10 cm compr., lisos ou tuberculados. Sementes verrucosas.

Material selecionado: BRASIL. São Paulo: São Paulo: Reserva Biológica, Parque Estadual das Fontes do Ipiranga, 9-III-1978, M. Kirizawa 192 (SP).

Ilustração em Fontella-Pereira (2005).

\subsection{Oxypetalum insigne (Decne.) Malme, Ark. Bot.} 21A(3): 31. 1927.

Trepadeira herbácea, volúvel; látex branco. Ramos vilosos. Folhas simples, opostas; lâmina 3-8 $\times 1$-4 cm, oval-lanceolada a oboval, pubescente; ápice acuminado, arredondado-mucronado; margem frequentemente revoluta; base arredondada, cordiforme; 2-5 coléteres na base da face adaxial; venação eucamptódroma. Inflorescências em corimbos, 3-6 flores; sépalas triangular-lanceoladas, glabras a tomentosas externamente; corola creme-esverdeada, base castanha, segmentos da corona ultrapassando ou não as anteras. Folículos ovais ou fusiformes, $6-8 \mathrm{~cm}$ compr., liso ou tuberculado. Sementes verrucosas.

Material selecionado: BRASIL. São Paulo: São Paulo, Parque Estadual das Fontes do Ipiranga, 7-V-1936, F.C. Hoehne s.n. (SP38561).

3.13. Oxypetalum pachyglossum Decne. in A. DC., Prodr. 8: 585. 1844.

Trepadeira herbácea, volúvel; látex branco. 
Ramos glabros. Folhas simples, opostas; lâmina 5-15 × 0,7-4 cm, oblongo-lanceolada, glabra; ápice acuminado; margem lisa; base cordiforme; face adaxial pubescente nas nervuras; $2-5$ coléteres na base da face adaxial; venação eucamptódroma. Inflorescências em cimeiras, 5-6 flores; sépalas triangular-lanceoladas, pubescentes externamente; corola amarelo-esverdeada, segmentos da corona ultrapassando as anteras. Folículos ovais ou fusiformes, 8-9 cm compr., liso ou tuberculado. Sementes verrucosas.

Material selecionado: BRASIL. São PAulo: São Paulo, Parque Estadual das Fontes do Ipiranga, 14-XI-1980, M.R.F. Melo et al. 241 (SP).

Ilustração em Fontella-Pereira (2005).

\subsection{Oxypetalum wightianum Hook. \& Arn., J. Bot.} (Hooker) 1: 288. 1834.

Trepadeira herbácea, volúvel; látex branco. Ramos tomentosos. Folhas simples, opostas; lâmina 4-9 × 1,5-4 cm, oblongo-triangular, puberulenta; ápice acuminado; margem lisa; base cordiforme a sagitada; 2-5 coléteres na base da face adaxial; venação eucamptódroma. Inflorescências em corimbos, 2-4 flores; sépalas linear-lanceoladas, pubescente externamente; corola verde-amarelada, lobos levemente torcidos, segmentos da corona mais curtos que as anteras, esverdeados. Folículos ovais ou fusiformes, 4-7,5 cm compr., liso ou tuberculado. Sementes verrucosas.

Material selecionado: BRASIL. São PaUlo: São Paulo, Parque Estadual das Fontes do Ipiranga, 28-I-1932, F.C. Hoehne s.n. (SP29551).

Ilustração em Fontella-Pereira (2005).

3.15. Peltastes peltatus (Vell.) Woodson, Ann. Missouri Bot. Gard. 19(4): 376. 1932.

Trepadeira lenhosa, volúvel; látex translúcido. Ramos jovens tomentosos-ferrugíneos. Folhas simples, opostas, peltadas; lâmina 7-12,2 × 5-7 cm, oval, coriácea; ápice atenuado; margem inteira; base peltada; face adaxial pubérula; face abaxial pubescente; venação broquidródoma; pecíolo 2,5-4,5 cm compr.; tomentoso a pubérulo; coléteres ausentes; venação broquidódroma. Inflorescências em cimeiras; sépalas oblongas, 5 coléteres na base da face adaxial; corola esverdeada, 4-6,5 cm compr. Folículos cilíndricos, curvos, concrescentes no ápice, $22-35 \times 1,1-1,3 \mathrm{~cm}$. Sementes comosas.
Material selecionado: BRASIL. São Paulo: São Paulo, Reserva Biológica, Parque Estadual das Fontes do Ipiranga, 4-XI-1981, S.L. Jung \& M.G. Wanderley 407 (SP).

Ilustração em Kinoshita (2005).

3.16. Prestonia coalita (Vell.) Woodson, Ann. Missouri Bot. Gard. 18(4): 552. 1931.

Trepadeira lenhosa, volúvel; látex translúcido. Ramos glabros, lenticelas abundantes. Folhas simples, opostas; lâmina 6-14 × 2-4,5 cm, elíptica a oblonga, glabra; ápice acuminado; margem inteira; base obtusa a arredondada; coléteres ausentes; venação broquidódroma. Inflorescências em racemos, axilares, 5-16 flores; sépalas 4-6 mm, pubérulas; corola amarelo-esverdeada, 1,5-2 cm compr., tubo 0,5-1 cm compr. Folículos delgados, cilíndricos, unidos no ápice, 30-50 cm compr. Sementes comosas.

Material selecionado: BRASIL. São PAUlo: São Paulo, Parque Estadual das Fontes do Ipiranga, 11-II-1970, T. Sendulsky 833 (SP).

Ilustração em Kinoshita (2005).

3.17. Secondatia densiflora A. DC., Prodr. 8: 445. 1844.

Figura 4

Trepadeira lenhosa, escandente; látex branco. Ramos glabros, lenticelas abundantes. Folhas simples, opostas; lâmina 7,5-9,5 × 3,5-4,5 cm, oblongoelíptica, glabras; ápice acuminado; margem inteira; base atenuada a obtusa; coléteres ausentes; venação broquidódroma. Inflorescências em tirsos, axilares, 8-25 flores; sépalas 2-2,5 mm, glabras; corola alva, 6,5-9 × 1,5-2 mm compr., pubescente. Folículos fusiformes, $12-19 \mathrm{~cm}$ compr. Sementes comosas.

Material selecionado: BRASIL. São Paulo: São Paulo, Parque Estadual das Fontes do Ipiranga, 24-I-2007, B.L.P. Villagra 177 (SP).

Ilustração em Kinoshita (2005)

3.18. Tassadia subulata (Vell.) Fontella \& E.A. Schwarz, Bol. Mus. Bot. Munic. 57: 1. 1982.

Trepadeira herbácea, volúvel; látex branco. Ramos pubérulos. Folhas simples, opostas, sésseis; lâmina 0,6-1 cm compr., linear, pubérula; ápice agudo; margem inteira; base aguda; 2-3 coléteres na 
base da nervura principal; venação broquidódroma. Inflorescências em tirsos; flores 1-5, sésseis; sépalas ovais, pubescentes externamente; corola vinácea, alva, esverdeada ou amarela, segmentos da corona arredondados, não ultrapassando a base das anteras. Folículos fusiformes, lisos e estriados, $10-30 \mathrm{~cm}$ compr. Sementes comosas e verrucosas.

Material selecionado: BRASIL. São PAULo: São Paulo, Parque Estadual das Fontes do Ipiranga, VI-1944, W. Hoehne s.n. (SP312387).

Ilustração em Fontella-Pereira (2005).

\section{ARISTOLOCHIACEAE}

4.1. Aristolochia galeata Mart. in Mart. \& Zucc., Nov. Gen. sp. pl. 1: 76, tab. 50. 1824.

Trepadeira herbácea, volúvel. Ramos glabros. Folhas simples, alternas; lâmina 7-11 × 12-14 cm, reniforme, face adaxial pubescente, face abaxial glabra, membranácea; ápice obtuso; margem inteira; base auriculada; venação actinódroma basal; pseudoestípulas. Flores solitárias; perigônio bilabiado, velutino, purpúreo a verde; lábio inferior lanceolado, verde-limão; lábio superior estipitado, abrindo-se em lâmina transversalmente elíptica de extremidade emarginada, branco-amarelado; 6-7 × 10-12 cm. Cápsulas septicidas, hexagonais, 5-6 cm compr. Sementes 10-13 cm compr.

Material selecionado: BRASIL. São PAulo: São Paulo, Parque Estadual das Fontes do Ipiranga, 30-XII-1940, O. Handro s.n. (SP47060).

Ilustração em Capellari Junior (2002).

\subsection{Aristolochia melastoma Manso ex Duch. in DC.,}

Prodr. 15(1): 460. 1864.

Figura 5

Trepadeira herbácea, volúvel. Ramos híspidos. Folhas simples, alternas; lâmina 5-11,5 × 1-3,8 cm, elíptica a lanceolada, pubescente, membranácea; ápice agudo; margem inteira; base auriculada; 3-nervada; venação actinódroma basal; pseudoestípulas ausentes. Inflorescências em racemos; 2-7 flores; perigônio unilabiado, pubescente, amarelo a castanho; lábio oval; tubo curvado na base; fauce manchada amarelo-queimado; 1,6-2,5 cm compr. Cápsulas septicidas, globosas, 1,5-2,8 cm compr. Sementes 3-4 cm compr.
Material selecionado: BRASIL. São PaUlo: São Paulo, Parque Estadual das Fontes do Ipiranga, 16-I-2007, B.L.P. Villagra 171 (SP).

Ilustração em Capellari Junior (2002).

\section{ASTERACEAE}

5.1. Calea pinnatifida (R. Br.) Less., Linnaea 5: 158. 1830.

Trepadeira herbácea, escandente. Ramos hexagonais, inermes, púberulos a glabros. Folhas simples, opostas; lâmina 2,5-8 × 0,8-3 cm, deltóide a lanceolada, cartácea; face adaxial glabra; face abaxial pubérula na nervura; ápice acuminado; margem com 3-4 lobos; base cuneada a obtusa; venação eucamptódroma; estípulas ausentes. Inflorescências em corimbos, terminais; capítulos radiados; brácteas involucrais glabras, as externas oblongas; flores do raio 5-7, do disco 15-17; corola campanulada, glabra. Cipsela glabra; pápus paleáceo, ca. 20 páleas, 4-4,5 mm compr.

Material selecionado: BRASIL. São Paulo: São Paulo, Parque Estadual das Fontes do Ipiranga, 15-III-1993, J.V. Godoi 327 (SP).

5.2. Cyrtocymura scorpioides (Lam.) H. Rob., Proc.

Biol. Soc. Wash. 100(4): 852. 1987.

Trepadeira herbácea, escandente. Ramos estriados, inermes, pubescentes, casca não descamante, esverdeada. Folhas simples, alternas; lâmina 1,7-11,5 × 0,5-3,2 cm, elíptica a lanceolada; face adaxial pubérula; face abaxial alvo-tomentosa; ápice acuminado; margem serreada; base longo-atenuada; venação broquidódroma; pecíolo 3-6 mm compr., glândulas ausentes; nectários ausentes; ócreas ausentes. Inflorescências em cincinos, terminais; capítulos 2-175 flores, sésseis, brácteas involucrais 2-8, seríceas, ovado-lanceoladas; flores 30-35, corola tubulosa, 5-lobadas, glabra. Cipsela cilíndrico-turbinada, serícea, ca. $1 \mathrm{~mm}$ compr.; pápus cerdoso, alvo, 5-6 mm compr.

Material selecionado: BRASIL. São Paulo: São Paulo, Parque Estadual das Fontes do Ipiranga, 28-VII-2006, B.L.P. Villagra 107 (SP).

Observações: Souza (2007) considerou esta espécie como Vernonia scorpioides (Lam.) Pers., não aceitando a divisão do gênero proposta por Robinson (1999).

Ilustrações em Robinson (1999) e Souza (2007). 
5.3. Dasyphyllum brasiliense (Spreng.) Cabrera,

Revista Mus. La Plata, Secc. Bot. 9: 72. 1959.

Trepadeira herbácea, escandente. Ramos armados, espinhos axilares curvos, dispersos. Folhas simples, alternas; lâmina 1-12 × 0,6-4 cm, elíptica, obovada, glabra; ápice apiculado; margem inteira; base obtusa; venação eucamptódroma. Inflorescências em corimbos; capítulos discóides; brácteas involucrais mais de 20, as externas ovadas; flores 10-14, díclinas ou pistiladas; corola tubulosa, hirsuta. Cipsela obovóide, velutina; pápus plumoso, 7-9 mm compr.

Material selecionado: BRASIL. São Paulo: São Paulo, Parque Estadual das Fontes do Ipiranga, 2-VIII-1934, F.C. Hoehne s.n. (SP31958).

\subsection{Mikania buddleiaefolia DC., Prodr. 5: 192. 1836.}

Trepadeira herbácea, volúvel, látex ausente. Ramos cilíndricos, estriados, pubérulos, tricomas glandulares, entrenós 1,5-4,5 cm. Folhas simples, opostas; lâmina 5-6,5 × 1,7-3,5 cm, oval, discolor; face adaxial glabra; face abaxial lanosa; cinérea; ápice agudo; margem inteira; base arredondada; venação broquidódroma; estípulas ausentes; nectários ausentes; pecíolo 0,7-1,3 cm compr. Inflorescências em panículas amplas, formadas por espigas reduzidas; capítulos discóides, 3-4; brácteas subinvolucrais ovais; brácteas involucrais 4, oblongas, lanosas, pubérulas; flores 4; corola tubulosa, tubo ca. $0,7 \mathrm{~mm}$ compr., glabra, lobos triangulares. Cipsela 5-costada, ca. $2 \mathrm{~mm}$ compr.; pápus cerdoso, 35-60 cerdas, ca. 2,5 mm.

Material selecionado: BRASIL. São Paulo: São Paulo, Parque Estadual das Fontes do Ipiranga, 25-IX-1945, W. Hoehne 1850 (SP).

\subsection{Mikania campanulata Gardner, London J. Bot.}

5: 489. 1846.

Trepadeira herbácea, volúvel, látex ausente. Ramos cilíndricos, estriados; internós 9-16 cm compr. Folhas simples, opostas; lâmina 5-9 × 4-8 cm; deltóide, glabra ou pubérula na nervura e margem; ápice acuminado a agudo; margem inteira; base cordada; venação actinódroma; 2 pares de nervuras basais; estípulas ausentes; nectários ausentes; pecíolo 3-6 cm compr. Inflorescências em panículas amplas; capítulos discóides; brácteas subinvolucrais lineares; brácteas involucrais 4 , elípticas, glabras; flores 4; corola tubulosa, tubo ca. 1,8-2 mm compr., glabro, lobos triangulares. Cipsela 5-costada, 2-2,5 mm compr., pápus cerdoso, 35-60 cerdas, ca. $4 \mathrm{~mm}$ compr.
Material selecionado: BRASIL. SÃo PAULO: São Paulo, Parque Estadual das Fontes do Ipiranga, 27-VII-1977, S.L. Jung \& C.E.F. Castro 41 (SP).

Ilustração em Ritter \& Miotto (2005).

5.6. Mikania chlorolepis Baker in Mart., Fl. bras. 6(2): 247. 1876.

Trepadeira herbácea, volúvel; látex ausente. Ramos cilíndricos, fistulosos, estriados, viloso-pubérulos; entrenós 5-18 cm compr. Folhas simples, opostas; lâmina 10-16 × 2-3,5 cm, lanceolada, membranácea, pubescência concentrada na nervura; 2 projeções no terço inferior; ápice acuminado; margem inteira; base cuneada; venação broquidódroma, decorrente no pecíolo; estípulas ausentes; nectários ausentes; pecíolo ca. $0,5 \mathrm{~cm}$ compr. Inflorescências em cimeiras; capítulos discóides; brácteas subinvolucrais membranáceas, ovais, viloso-pubérulas; ciliadas; brácteas involucrais 4, oblongas, glabras; flores 4; corola tubulosa, glabra; tubo ca. 0,5 mm compr.; lobos triangulares. Cipsela 5-costada, papus 35-60 cerdas.

Material selecionado: BRASIL. São PaUlo: São Paulo, Parque Estadual das Fontes do Ipiranga, 13-VI-1932, F.C. Hoehne s.n. (SP29740).

Ilustração em Ritter \& Miotto (2005).

5.7. Mikania glomerata Spreng., Syst. Veg. Fl. Peruv. Chil. 3: 421. 1826.

Figura 6

Trepadeira lenhosa, volúvel; látex ausente. Ramos cilíndricos, fistulosos, estriados, glabros; internós 9-17 cm compr. Folhas simples, opostas; lâmina 8-13 × 6-14 cm, oval a triangular, glabra, cartácea; ápice acuminado; margem inteira; base hastada; venação acródroma; 3-5 nervuras basais; estípulas ausentes; nectários ausentes; pecíolo 3-7 cm compr., estriado, glabro. Inflorescências em glomérulos, axilares e terminais; capítulos discóides sésseis; brácteas subinvolucrais escamiformes; brácteas involucrais 4, elípticas, glabras; flores 4; corola tubulosa, tubo ca. 1,5 $\mathrm{mm}$ compr., glabra, lobos triangulares. Cipsela 5-costada, 1-3 mm compr.; pápus cerdoso, 35-60 cerdas, creme.

Material selecionado: BRASIL. São PaUlo: São Paulo, Parque Estadual das Fontes do Ipiranga, 18-XII-2006, B.L.P.Villagra 152 (SP).

Ilustração em Ritter \& Miotto (2005). 
5.8. Mikania hirsutissima DC., Prodr. 5: 200. 1836. Figura 7

Trepadeira lenhosa, volúvel; látex ausente. Ramos cilíndricos, vilosos, tricomas dourados; entrenós 7-25 cm compr. Folhas simples, opostas; lâmina 8-10 × 5-9 cm, oval, membranácea; face adaxial estrigosa; face abaxial vilosa, tricomas hialinos; ápice agudo a acuminado, tricoma glandular no ápice; margem inteira; base cordada; venação actinódroma, 2-3 pares de nervuras basais; estípulas ausentes; nectários ausentes; pecíolo 4-6 cm compr. Inflorescências em panículas; capítulos discóides; brácteas subinvolucrais ovais; brácteas involucrais 4, oblongas, lanuginosa; flores 4; corola tubulosa, amarela; tubo ca. 1,8 mm compr., glabro, lobos ovais. Cipsela 5-costada, ca. $3 \mathrm{~mm}$ compr.; pápus cerdoso, 35-60 cerdas, creme, ca. $4 \mathrm{~mm}$ compr.

Material selecionado: BRASIL. São PAUlo: São Paulo, Parque Estadual das Fontes do Ipiranga, 5-X-2006, B.L.P. Villagra 165 (SP).

\subsection{Mikania laevigata Sch. Bip. ex Baker in Mart.,}

F1. bras. 6(2): 241. 1876.

Trepadeira herbácea, volúvel. Ramos cilíndricos, estriados, glabros, internós 3-15 cm compr. Folhas simples, opostas; lâmina 6-12 × 3-5,5 cm; oval a lanceolada, coriácea, glabra; ápice agudo a acuminado; margem inteira; base arredondada a obtusa; venação acródroma; 5 nervuras basais ou supra-basais; estípulas ausentes; nectários ausentes; pecíolo 1,6-3 cm compr., caniculado, glabro. Inflorescências em espigas, densas, axilares; capítulos discóides; brácteas subinvolucrais triangulares, escamiformes; brácteas involucrais 4, oblongas a elípticas, pubérulas; flores 4; corola tubulosa, verde-amarelada, tubo ca. 1,2 mm compr., glabro, lobos triangulares. Cipsela 5-costada, 2-3 mm compr.; pápus cerdoso, 35-60 cerdas, creme a rosado, 4,5-5 mm compr.

Material selecionado: BRASIL. São PaUlo: São Paulo, Parque Estadual das Fontes do Ipiranga, 22-X-1934; F.C. Hoehne s.n. (SP32101).

Ilustração em Ritter \& Miotto (2005) e Souza (2007).

5.10. Mikania lanuginosa DC., Prodr. 5: 201. 1836.

Trepadeira lenhosa; volúvel; látex ausente. Ramos cilíndricos, lisos, pubérulos, alvo-lanosos nos ramos jovens; internós 4,5-7 cm compr. Folhas simples, opostas; lâmina 6-10 × 4-7 cm; oval, membranácea; face adaxial estrigosa; face abaxial seríceo-prateada, tricomas adpressos; ápice acuminado; margem curto-denteada, com tricoma glandular no ápice de cada dente; base cordada; venação actinódroma; 2-3 pares nervuras basais, lanosas; estípulas ausentes; nectários ausentes; pecíolo 3-4,5 cm compr. Inflorescências em panículas amplas, formadas por cimeiras; capítulos discóides; brácteas subinvolucrais elípticas; brácteas involucrais 4, oblongas, pubescentes; flores 4; corola tubulosa, amarela, tubo ca. 1,2 mm compr., glabro, lobos lanceolados. Cipsela 5-costada; pápus ca. $3 \mathrm{~mm}$ compr., creme.

Material selecionado: BRASIL. São Paulo: São Paulo, Parque Estadual das Fontes do Ipiranga, 23-VII-1974, M. Sakane 130 (SP).

\subsection{Mikania lasiandrae DC., Prodr. 5: 189. 1836.}

Trepadeira lenhosa, volúvel; látex ausente. Ramos cilíndricos, seríceo-vilosos; entrenós 2-5 cm compr. Folhas simples, opostas; lâmina 7-14 × 3-5 cm, lanceolada, membranácea; face adaxial estrigosa; face abaxial serícea, amarelada; ápice acuminado; margem inteira; base cuneada, assimétrica; venação broquidódroma; estípulas ausentes; nectários ausentes; pecíolo 1-2 cm compr. Inflorescências em panículas; capítulos discóides; brácteas subinvolucrais ovais; brácteas involucrais 4, oblongas, flores 4; corola tubulosa, alva, tubo 1-1,2 mm compr., glabro, lobos triangulares a lanceolados. Cipsela 5-costada, 3,5-4 mm compr.; pápus cerdoso, 35-60 cerdas, ca. $4 \mathrm{~mm}$ compr.

Material selecionado: BRASIL. São PAulo: São Paulo, Parque Estadual das Fontes do Ipiranga, 31-I-2006, B.L.P. Villagra 66 (SP).

\subsection{Mikania micrantha Kunth, Nov. gen. sp. 4:}

134. 1818 (1820).

Trepadeira herbácea, volúvel; látex ausente. Ramos angulosos, estriados, glabros a pubescentes; internós 4,5-13 cm compr. Folhas simples, opostas; lâmina 2-7 × 2-8 cm, cordiforme, membranácea, glabra; ápice acuminado; margem crenada a denteada; base cordada; venação acródroma; 1-2 pares nervuras basais; estípulas ausentes; nectários ausentes; pecíolo 2,5-8 cm compr., estriado a sulcado, glabro a pubérulo. Inflorescências em corimbos; axilares e terminais; capítulos discóides; brácteas subinvolucrais 

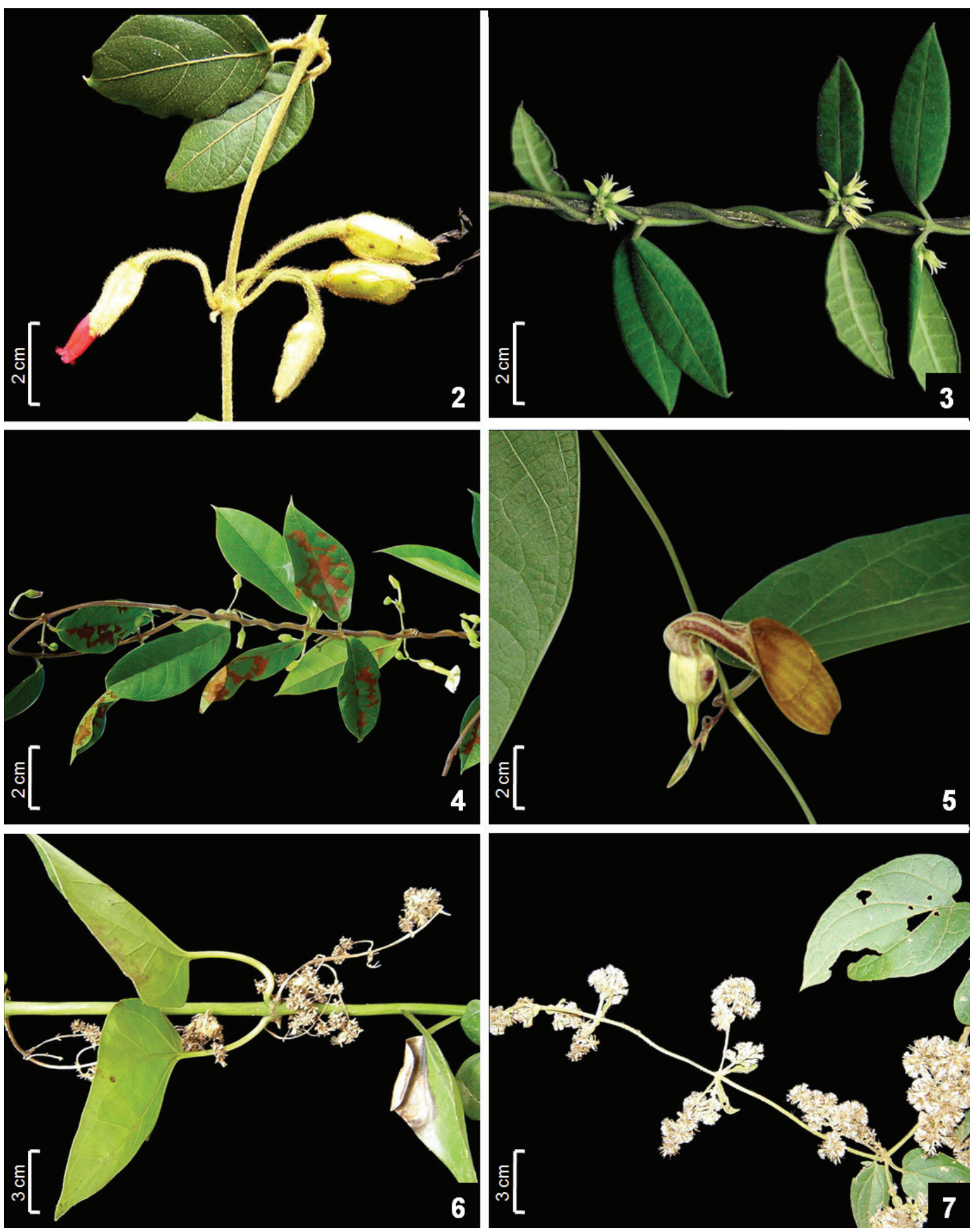

Figura 2-7. Acanthaceae. 2. Mendoncia sp. Apocynaceae. 3. Ditassa tomentosa. 4. Secondatia densiflora. Aristolochiaceae. 5. Aristolochia melastoma. Asteraceae. 6. Mikania glomerata. 7. Mikania hirsutissima.

Figure 2-7. Acanthaceae. 2. Mendoncia sp. Apocynaceae. 3. Ditassa tomentosa. 4. Secondatia densiflora. Aristolochiaceae. Aristolochia melastoma. Asteraceae. 6. Mikania glomerata. 7. Mikania hirsutissima. 
lanceoladas a lineares; brácteas involucrais 4, lanceoladas a elípticas, glabras; flores 4; corola tubulosa, alva; tubo ca. $2 \mathrm{~mm}$ compr., glândulas sésseis esparsas, lobos triangulares. Cipsela 5-costada, 1-2 mm compr.; pápus cerdoso, 35-60 cerdas, alvo, ca. $3,8 \mathrm{~mm}$ compr.

Material selecionado: BRASIL. São Paulo: São Paulo, Parque Estadual das Fontes do Ipiranga, 18-VII-1977, H. Makino 72 (SP).

Ilustração em Ritter \& Miotto (2005) e Souza (2007).

\subsection{Mikania oblongifolia DC., Prodr. 5: 188. 1836.}

Trepadeira lenhosa, escandente. Ramos cilíndricos, inermes, estriados, glabros; entrenós 1,5-3 cm compr. Folhas simples, opostas, sésseis; lâmina 4-7,5 × 1,2-2,7 cm, elíptica, glabra; ápice obtuso; margem revoluta; base arredondada; venação broquidódroma; estípulas ausentes. Inflorescências em racemos duplos; capítulos discóides; brácteas subinvolucrais elípticas; brácteas involucrais 4, elípticas, glabras; flores 4; corola tubulosa, alva, tubo ca. $2 \mathrm{~cm}$ compr., lobos lanceolados. Cipsela 5-costada, ca. 2,2 mm compr.; pápus cerdoso, 35-60 cerdas, creme, ca. 5,0 mm compr.

Material selecionado: BRASIL. São PaUlo: São Paulo, Jardim Botânico de São Paulo, 2-II-1934, F.C. Hoehne s.n. (SP36655).

\subsection{Mikania rufescens Sch. Bip. ex Baker in Mart.,} Fl. bras. 6(2): 238. 1876.

Trepadeira herbácea, volúvel; látex ausente. Ramos cilíndricos, estriados, glabros, vermelho-escuros; internós 5-15 cm compr. Folhas simples, opostas; lâmina 8-15 × 6-14 cm, oval; glabra, cartácea; ápice acuminado; margem inteira; base obtusa a arredondada; venação acródroma; 2-3 pares nervuras basais; estípulas ausentes; nectários ausentes; pecíolo 3-7 cm compr., canaliculado na face adaxial, glabro. Inflorescências em corimbos; terminais e axilares; capítulos discóides, sésseis; brácteas subinvolucrais elípticas; brácteas involucrais 4, oblongas, glabras; flores 4; corola tubulosa, alva; tubo ca. $4 \mathrm{~mm}$ compr., pubescente, lobos elípticos. Cipsela 5-costada, 2-4 mm compr.; pápus cerdoso, 35-60 cerdas, amarelo a alaranjado.

Material selecionado: BRASIL. São PAUlo: São Paulo, Parque Estadual das Fontes do Ipiranga, 29-VIII-1977, H. Makino 82 (SP).

Ilustração em Ritter \& Miotto (2005) e Souza (2007).
5.15. Mikania trinervis Hook. \& Arn., Compan. Bot. Mag. 1: 244. 1835.

Trepadeira herbácea, volúvel. Ramos angulosos, estriados, glabros; internós 3-18 cm compr. Folhas simples, opostas; lâmina 5-9,5 × 2,5-3,5 cm, oval a elíptica, glabra, cartácea; ápice a gudo a acuminado; margem inteira; base obtusa a aguda; venação acródroma; 2 primeiros pares de nervuras conspícuas; estípulas ausentes; nectários ausentes; pecíolo 0,6-1,3 cm compr., glabro. Inflorescências em tirsos; terminais e axilares; capítulos discóides; brácteas subinvolucrais ovais; brácteas involucrais 4 , oblongas, pubérulas; flores 4; corola tubulosa, alva a creme, tubo ca. 1-1,2 mm compr., glabro, lobos triangulares. Cipsela 5-costada, 3,5-4 mm compr.; pápus cerdoso, 35-60 cerdas, creme.

Material selecionado: BRASIL. São Paulo: São Paulo, Parque Estadual das Fontes do Ipiranga, 13-VIII-1968, T. Sendulsky 1000 (SP).

Ilustração em Ritter \& Miotto (2005) e Souza (2007).

\subsection{Mutisia speciosa Aiton ex Hook., Bot. Mag. 54:} tab. 2705. 1827.

Trepadeira herbácea, preensil; 1 gavinha ramificada na raque foliar. Ramos 4-angulosos, às vezes estreito-alados. Folhas simples, alternas; lâmina 2,9-5,7 × 1,1-2 cm, elíptica a lanceolada, pinatissecta; face adaxial glabra; face abaxial lanuginosa ou glabrescente; ápice agudo; margem inteira; base cuneiforme; ráquis até 14 cm compr.; venação eucamptódroma. Inflorescências em capítulos; brácteas involucrais mais de 20, as externas ovado-lanceoladas, glabras; flores marginais 13-20, pistiladas; corola bilabiada $(3+2)$; 4-4,5 cm compr., limbo revoluto; flores do disco monóclinas; corola bilabiada $(3+2), 3-3,5 \mathrm{~cm}$ compr. Cipsela cilíndrica, 1,5-1,7 cm compr.; pápus plumoso, palhete, 2,6-3 cm compr.

Material selecionado: BRASIL. São Paulo: São Paulo, Parque Estadual das Fontes do Ipiranga, Mata da Vila Facchini, 28-XI-1980, S.L. Jung \& F. Barros 368 (SP).

5.17. Piptocarpha oblonga (Gardner) Baker in Mart., Fl. bras. 6(2): 121. 1873.

Trepadeira lenhosa, escandente Ramos cilíndricos, castanhos, inermes, não descamantes, pubescentes. Folhas simples, alternas; lâmina 3-9,5 × 1,6-3 cm, 
oblongo-lanceolada, discolor, coriácea; face adaxial glabra; verde quando seca; face abaxial pubescente, alva, tricomas estrelado-tomentosos; ápice agudo a acuminado; margem inteira, dentículos esparsos; base obtusa; venação broquidódroma; estípulas ausentes; nectários ausentes; ócrea ausente; pecíolo 5-10 cm, sulcado, pubescente. Inflorescências em glomérulos, axilares; capítulos mais de 15; brácteas involucrais ovais externamente, lanceoladas internamente, palhetes; flores 3 ; corola tubulosa, $0,5-0,7 \mathrm{~cm}$ compr., glabra. Cipsela 3-4 angulosa, 0,4-0,5 cm compr.; pápus 0,6-0,65 cm compr., branco, cerdas filiformes.

Material selecionado: BRASIL. São PaUlo: São Paulo, Parque Estadual das Fontes do Ipiranga, 5-VIII-1981, S.L. Jung et al. 397 (SP).

Ilustração em Souza (2007).

5.18. Piptocarpha pyrifolia (DC.) Baker in Mart., Fl. bras. 6(2): 120. 1873.

Trepadeira herbácea, escandente. Ramos cilíndricos, castanhos, inermes, não descamantes, estriados, cinéreos, lepidoto-tomentosos, posteriormente pubescentes. Folhas simples, alternas; lâmina 3,5-8,5 × 1,2-3,2 cm, elíptica; face adaxial lepidoto-tomentosa; face abaxial lepidoto-tomentosa, glanduloso pontuada; ápice acuminado; margem inteira; levemente revoluta; venação broquidódroma; nectários ausentes; ócrea ausente; pecíolo 0,5-1 cm compr. Inflorescências em glomérulos; capítulos mais de 10 , sésseis; brácteas involucrais ovais externamente, oblongas internamente; flores 3; corola tubulosa, 0,8-1 cm compr., glabra; lobos com ápice papiloso. Cipsela 3-angulosa, 0,4-0,6 cm compr.; pápus $0,7-0,9 \mathrm{~cm}$ compr., cerdas filiformes.

Material selecionado: BRASIL. São PaUlo: São Paulo, Reserva Biológica, Parque Estadual das Fontes do Ipiranga, 4-VI-1984, C.B. Toledo et al. 34 (SP).

\subsection{Piptocarpha quadrangularis (Vell.) Baker in}

Mart., Fl. bras. 6(2): 128. 1873.

Figura 8a, b

Trepadeira lenhosa, escandente. Ramos quadrangulares, inermes, não descamantes, costados, castanhos. Folhas simples, alternas; lâmina $7-18 \times 2,5-8,5 \mathrm{~cm}$, elíptica a ovada; face adaxial glabra; face abaxial pubescente, tricomas estrelados; ápice agudo a acuminado; margem levemente ondulada; base aguda; venação broquidódroma; glândulas ausentes; nectários ausentes; ócrea ausente; pecíolo 1-2,5 cm compr., costado. Inflorescências em corimbos; capítulos mais de 30; brácteas involucrais ovais externamente, lanceoladas internamente; flores 3 ; corola tubulosa, 0,7-0,9 cm compr., glabra. Cipsela 10-costada, glandulosa pontuada; pápus $0,5-0,7 \mathrm{~cm}$ compr., cerdas paleáceas, filiformes.

Material selecionado: BRASIL. São PAUlo: São Paulo, Parque Estadual das Fontes do Ipiranga, 16-I-2007, B.L.P. Villagra 168 (SP).

\subsection{Trixis antimenorrhoea (Schrank) Kuntze, Revis.}

Gen. Pl. 3(2): 182. 1898.

Trepadeira herbácea, escandente. Ramos cilíndricos, tomentosos. Folhas simples, opostas; lâmina 4,5-13,5 × 1,2-3 cm, lanceolada; face adaxial setosa, verde pilosa; face abaxial alvo-tomentosa, glanduloso pontuada; ápice acuminado; margem denticulada; base atenuada; venação broquidódroma; pecíolo 0,1-0,5 cm compr. Inflorescências em panículas; capítulos pedunculados; brácteas involucrais 2-seriadas, linear-lanceoladas, externas 5-7, internas 7-9; flores 10-12; corola bilabiada, $0,8-1,1 \mathrm{~cm}$ compr., verde a castanha. Cipsela 5-costada, 0,4-0,5 cm compr.; pápus 2-multisseriado, 0,8-1,1 cm compr., palhete.

Material selecionado: BRASIL. São PAUlo: São Paulo, Parque Estadual das Fontes do Ipiranga, 28-VII-2006, B.L.P. Villagra 110 (SP).

\section{BIGNONIACEAE}

\subsection{Amphilophium crucigerum (L.) L.Lohmann,}

Nuevo Cat. Fl. Vasc. Venezuela: 273. 2008.

Trepadeira lenhosa, preensil; gavinha 15-ramificada, unhas e discos ausentes. Ramos 6-8 angulosos, tomentosos. Folhas 2-3 folioladas, opostas; lâmina 7-10 × 6-9 cm, oval a suborbicular, pubescente; ápice obtuso a agudo; base cordada a subauriculada; venação actinódroma basal, 5-nervada; pecíolo 3-8 cm compr.; peciólulo 2-4 cm compr. Inflorescências em racemos; cálice cupuliforme, denticulado, pubérulo a tomentoso, $1 \mathrm{~cm}$ compr.; corola tubular-campanulada, alva, pubescente externamente, ca. $5 \mathrm{~cm}$ compr.; estames inclusos. Cápsulas lineares, muricadas, 21-24 cm compr.

Material selecionado: BRASIL. São Paulo: São Paulo, Parque Estadual das Fontes do Ipiranga, 21-VIII- 2006, B.L.P. Villagra 127 (SP). 


\subsection{Anemopaegma prostratum DC.,Prodr.9: 189. 1845.}

Trepadeira lenhosa, preensil; gavinha terminal simples. Ramos cilíndricos, glabros, estriados; sem áreas glandulares nos nós. Folhas 2-3 folioladas, opostas; lâmina 7-10 × 4,5-8,5 cm, oval a suborbicular, glabra; ápice agudo; base arredondada a subcordada; venação eucamptódroma; pecíolo 4-10 cm compr. Inflorescências em racemos axilares; cálice cupular, normalmente truncado, glanduloso nas margens; corola alva, creme na face interna, glabra, 4-5,5 cm compr.; estames inclusos. Cápsulas elipsóides, fortemente achatadas.

Material selecionado: BRASIL. São Paulo: São Paulo, Jardim Botânico de São Paulo, 25-XI-1931, O. Handro s.n. (SPF144373).

6.3. Arrabidaea chica (Humb. \& Bonpl.) Verl., Rev. Hort. 40: 154. 1868.

\section{Figura 9}

Trepadeira lenhosa, preensil; gavinha simples. Ramos cilíndricos, púberulos. Folhas 2-3 folioladas, opostas; lâmina 6-9 × 2,5-3,2 cm, oblongo-lanceolada a lanceolada, glabra, glândulas interpeciolares; ápice agudo a acuminado; base arredondada; venação eucamptódroma; pecíolo 3,5-4,5 cm compr.; peciólulo 0,6-2 cm compr. Inflorescências em panículas terminais amplas, multiflora; cálice campanulado, denticulado, glândulas no ápice; corola rósea, pubescente, ca. $3 \mathrm{~cm}$ compr.; estames inclusos. Cápsulas lineares, achatadas, glabras, 10-26 cm compr.

Material selecionado: BRASIL. SÃo PAULO: São Paulo, Parque Estadual das Fontes do Ipiranga, 22-II-2006, B.L.P. Villagra 50 (SP); B.L.P. Villagra 192 (SP).

Observações: espécie citada como Fridericia chica (Bonpl.) L.G. Lohmann no Catálogo de las Plantas Vasculares del Cono Sur (Arbo \& Lohmann 2008) e no Catálogo de Plantas e Fungos do Brasil (Lohmann 2010), esta combinação, porém, ainda não foi validamente publicada.

\subsection{Arrabidaea pulchella Bureau Vidensk. Meddels.} naturh. Foren. 99. 1893.

Trepadeira lenhosa, preensil; gavinha terminal simples. Ramos cilíndricos, jovens tomentosos a pubescentes. Folhas 2-3 folioladas, opostas; lâmina 2-4 × 1,5-2 cm, oval, glândulas interpeciolares, pubescente na nervura mediana; ápice obtuso a agudo; base normalmente arredondada, raramente obtusa; venação eucamptódroma; pecíolo ca. 1,5 cm compr., pubescente; peciólulo ca. 1,2 cm compr., pubescente. Inflorescências em subcorimbos, paucifloras; cálice campanulado, pubérulo externamente, pubescente internamente, lacínias longas, subulados, 0,7-0,9 cm compr.; corola infundibuliforme campanulada, rósea, pubescente, 3-3,2 cm compr.; estames inclusos. Cápsulas lineares, achatadas.

Material selecionado: BRASIL. São Paulo: São Paulo, Parque Estadual das Fontes do Ipiranga, 3-X-1944, W. Hoehne 1491 (SPF).

Observações: espécie citada como Fridericia pulchella (Bonpl.) L.G. Lohmann no Catálogo de las Plantas Vasculares del Cono Sur (Arbo \& Lohmann 2008), e no Catálogo de Plantas e Fungos do Brasil (Lohmann 2010), porém esta combinação não foi ainda validamente publicada.

6.5. Arrabidaea samydoides (Cham.) Sandw., Kew Bull. 22: 143. 1968.

Figura 10

Trepadeira lenhosa, preensil; gavinha simples. Ramos cilíndricos a subcilíndricos, pubescentes nos ramos jovens, estriados, lenticelados. Folhas 2-3 folioladas, opostas; lâmina 3,5-8,5 × 3-5 cm, elíptica, glândulas interpeciolares, pubescente; ápice acuminado a obcordado; base arredondada; venação eucamptódroma; pecíolo 0,2-0,6 cm compr.; peciólulo ca. $1 \mathrm{~cm}$ compr. Inflorescências em panículas a subcorimbos, terminais; cálice truncado, pubescente esparsamente; corola purpúrea, glabra, ápice tomentoso, $3,5-5 \mathrm{~cm}$ compr.; estames inclusos. Cápsulas lineares, achatadas, 13-25 cm compr.

Material selecionado: BRASIL. São Paulo: São Paulo, Parque Estadual das Fontes do Ipiranga, 23-III2007, B.L.P. Villagra 189 (SP); B.L.P. Villagra 14 (SP).

Observações: espécie citada como Fridericia samydoides (Cham.) L.G. Lohmann no Catálogo de las Plantas Vasculares del Cono Sur (Arbo \& Lohmann 2008), e no Catálogo de Plantas e Fungos do Brasil (Lohmann 2010), porém esta combinação ainda não foi validamente publicada.

6.6. Callichlamys latifolia (Rich.) K. Schum., Nat. Pflanzenf. 4 (3b): 223. 1894.

Trepadeira lenhosa, preensil; gavinha simples. Ramos cilíndricos, glabros. Folhas 2-3 folioladas, 
opostas; lâmina 9-12 × 4,5-6,5 cm, elíptica, glabra; ápice acuminado; base atenuada; venação broquidódroma; pecíolo 3,5-10,5 cm; peciólulo 1,5-3 cm compr. Inflorescências em racemos terminais; cálice inflado-campanulado, esparsamente furfuráceo, glanduloso, 2,5-3 cm compr.; corola amarelo-brilhante, glabra a esparsamente lepidota, 5,5-6 cm compr.; estames inclusos. Cápsulas oblongas ou elíptico-oblongas, 15-20 cm compr.

Material selecionado: BRASIL. São Paulo: São Paulo, Parque Estadual das Fontes do Ipiranga, 17-III-1944, W. Hoehne 1246 (SPF); 14-III-1944, O. Handro s.n. (SPF74813).

\subsection{Dolichandra quadrivalvis (Jacq.) L. Lohmann,}

Nuevo Cat. Fl. Vasc. Venezuela: 273. 2008. Figura 11

Trepadeira lenhosa, preensil; gavinha trífida, uncinada, normalmente caduca. Ramos cilíndricos, glabros. Folhas 2-3 folioladas, opostas; lâmina 6-12 × 4-5 cm, elíptica a oval; ápice agudo a obtuso; base assimétrica; venação actinódroma; pecíolo 2-3 cm compr.; peciólulo 0,6-1,5 cm compr. Inflorescências em panículas paucifloras; cálice subespatáceo, inflado, glabro, 1,5-2 cm compr., apículo ca. 0,2 cm compr.; corola amarela, glabra, 5-6 cm compr.; estames inclusos. Cápsulas elípticas, 8-15 cm compr.

Material selecionado: BRASIL. São Paulo: São Paulo, Parque Estadual das Fontes do Ipiranga, 23-I-2007, B.L.P. Villagra 218 (SP).

\subsection{Dolichandra unguis-cati (L.) L. Lohmann, Nuevo}

Cat. Fl. Vasc. Venezuela: 273. 2008.

Trepadeira lenhosa, preensil; gavinha trífida, uncinada. Ramos cilíndricos, pubérulos. Folhas 2 folioladas, opostas; lâmina 3,5-6,5 × 1,5-4,5 cm, oval a oblonga; face adaxial pubérula nas nervuras; ápice agudo a acuminado; face abaxial glabra; base atenuado a arredondada; venação eucamptódroma; pecíolo ca. $3 \mathrm{~cm}$ compr.; peciólulo 0,8-1 cm compr. Inflorescências em panículas; cálice cupular, membranáceo, subtruncado, glabro, glanduloso, ca. $1 \mathrm{~cm}$ compr.; corola amarela, glabra externamente, glandulosa internamente, $5-6,5 \mathrm{~cm}$ compr.; estames inclusos. Cápsulas linear-alongadas.

Material selecionado: BRASIL. São PaUlo: São Paulo, Parque Estadual das Fontes do Ipiranga, 25-X-1954, W. Hoehne 4063 (SPF).
6.9. Fridericia speciosa Mart., Nov. Acta Cur. 13. 1827.

Figura 12

Trepadeira lenhosa, preensil; gavinha simples. Ramos cilíndricos a subcilíndricos, pubérulos a lepidotos. Folhas 2-3 folioladas, opostas; lâmina 5,5$8 \times 2,5-3,2 \mathrm{~cm}$, elíptica, glândulas ausentes, lepidota; ápice agudo; base atenuada; pecíolo 2-5,5 cm compr.; venação broquidódroma; peciólulo $0,6-2,5 \mathrm{~cm}$ compr. Inflorescências em panículas terminais; cálice urceolado, tomentoso, vermelho, ca. 1,5 cm compr.; corola vermelha, tomentosa, ca. $2 \mathrm{~cm}$ compr.; estames inclusos. Cápsulas lineares.

Material selecionado: BRASIL. São PaUlo: São Paulo, Parque Estadual das Fontes do Ipiranga, 11-XII-2006, B.L.P. Villagra 159 (SP).

\subsection{Haplolophium bracteatum Cham., Linnaea 7:} 556. 1832.

Trepadeira lenhosa, preensil; gavinha terminal trífida, discos aderentes. Ramos angulosos lepidotos. Folhas 2-3 folioladas, opostas; lâmina 5-8 ×3,5-5 cm,oval a oblonga; venação eucamptódroma; pecíolo ca. 1,3cm compr.; peciólulo 1-1,8 cm compr. Inflorescências em panículas; cálice campanulado, margem ondulada, lepidoto densamente, ca. 2-3 cm compr.; corola curvada, inflada, tomentosa externamente, violácea de fauce amarela, 2-3 cm compr.; estames inclusos. Cápsulas equinadas, ovais.

Material selecionado: BRASIL. São PAUlo: São Paulo, Jardim Botânico de São Paulo, 23-X-1968, T. Sendulsky 925 (SP).

Observações: espécie citada como Amphilophium bracteatum (Cham.) L.G.Lohmann no Catálogo de las Plantas Vasculares del Cono Sur (Arbo \& Lohmann 2008) e no Catálogo de Plantas e Fungos do Brasil (Lohmann 2010), porém não foi ainda validamente publicada.

\subsection{Lundia virginalis DC. Adansonia 8: 282. 1867.}

Trepadeira lenhosa, preensil; gavinha simples. Ramos cilíndrico, pubérulos. Folhas 2-3 folioladas, opostas; lâmina 5-7,5 × 2-4,5 cm, oval, glândulas ausentes, membranácea, quando seca avermelhada; ápice agudo; base arredondada; venação eucamptódroma; pecíolo e peciólulo 1,5-2,5 cm compr. Inflorescências em racemos axilares; cálice trun- 

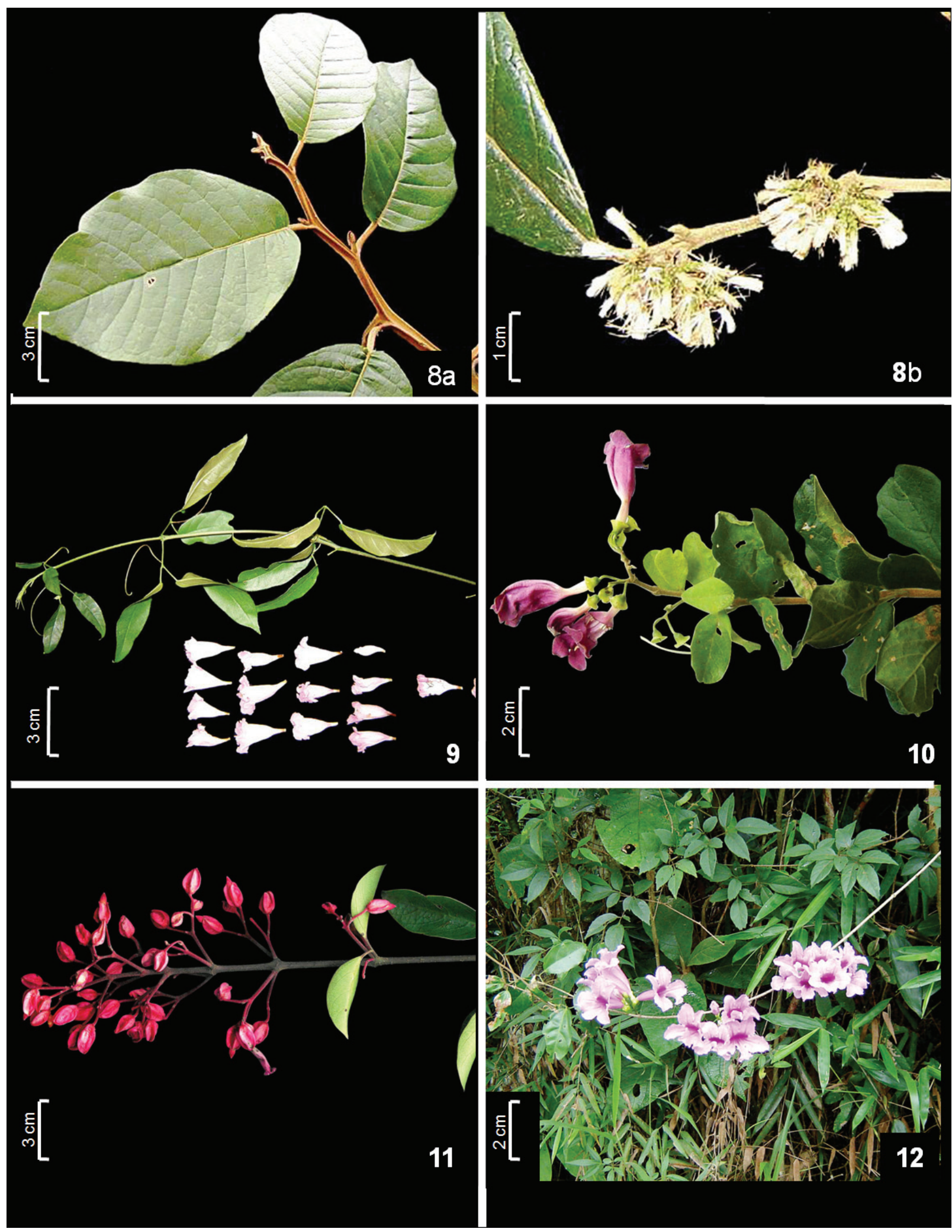

Figura 8-12. Asteraceae. 8. Piptocarpha quadrangularis. a. ápice do ramo. b. inflorescência. Bignoniaceae. 9. Arrabidaea chica. 10. Arrabidaea samydoides. 11. Dolichandra quadrivalvis. 12. Fridericia speciosa.

Figure 8-12. Asteraceae. 8. Piptocarpha quadrangularis. a. branch. b. inflorescense. Bignoniaceae. 9. Arrabidaea chica. 10. Arrabidaea samydoides. 11. Dolichandra quadrivalvis. 12. Fridericia speciosa. 
cado a 2-lobado, glabro, 0,4-0,6 cm compr.; corola alva, tomentosa na face externa, 4-4,5 cm compr.; estames inclusos. Cápsulas linear-alongadas, 22-34 cm compr.

Material selecionado: BRASIL. São Paulo: São Paulo, Jardim Botânico de São Paulo, 16-XI-1931, F.C. Hoehne s.n. (SP28457).

\subsection{Mansoa difficilis(Cham.) Bureau \& K. Schum., Fl.} bras. 8(2): 201. 1896.

Figura 13

Trepadeira lenhosa, preensil; gavinha trífida, unhas e discos ausentes. Ramos jovens glabros a pubérulos, estriados. Folhas 2-3 folioladas, opostas; lâmina 5-10 × 3-6 cm, oval, glabra, pubescente na base da nervura; ápice agudo a acuminado; base obtusa a arredondada; raramente subcordada; venação broquidódroma; pecíolo 2,5-4 cm compr.; peciólulo ca. $2,5 \mathrm{~cm}$ compr. Inflorescências em racemos paucifloros; cálice campanulado, truncado a denticulado, nervuras 5, proeminentes, margem ciliada, 0,5-0,7 cm compr.; corola lilás, pubérula, ca. $6 \mathrm{~cm}$ compr.; estames inclusos. Cápsulas linear-alongadas.

Material selecionado: BRASIL. São Paulo: São Paulo, Parque Estadual das Fontes do Ipiranga, Jardim Botânico de São Paulo, 30-III-1940, O. Handro 632 (SPF).

6.13. Mansoa schwackei Bureau \& K. Schum., Fl. bras. 8(2): 203. 1896.

Trepadeira lenhosa, preensil; gavinha trífida, unhas e discos ausentes. Ramos jovens pubérulos. Folhas 2-3 folioladas, opostas; lâmina 3-5 × 1-3 cm, oval, pubérula nas nervuras; ápice agudo a acuminado; base arredondada a subcordada; venação broquidódroma; pecíolo 1,5-2 cm compr.; peciólulo 0,9-1,2 cm compr. Inflorescências em racemos; cálice pubérulo, lacínias subuladas, dentes ca. 0,2 cm compr.; corola rósea, externamente subtomentosa; 4-4,5 cm compr.; estames inclusos. Cápsulas lineares, 13-18 cm compr.

Material selecionado: BRASIL. São Paulo: São Paulo, Jardim Botânico de São Paulo, 3-XI-1931, F.C. Hoehnes.n. (SP28427); Parque Estadual das Fontes do Ipiranga, 31-III-2006, B.L.P. Villagra 91 (SP).

Observações: espécie citada como Fridericia pulchella (Cham.) L.G. Lohmann no Catálogo de las
Plantas Vasculares del Cono Sur Arbo \& Lohmann 2008) e no Catálogo de Plantas e Fungos do Brasil (Lohmann 2010), porém não foi ainda validamente publicada. Essa espécie diferencia-se de Fridericia pulchella por apresentar a gavinha trífida.

\subsection{Parabignonia unguiculata (Vell.) A.H. Gentry,} Taxon 24: 343. 1975.

Trepadeira lenhosa, preensil; gavinha trífida, unhas e discos ausentes. Ramos cilíndricos, descamantes, glabros. Folhas 2-3 folioladas, opostas; lâmina 3,1-7 × 1,4-4,7 cm, elíptica a oboval, glabra, coriácea; ápice agudo, acuminado a obtuso; margem inteira; base aguda a obtusa; venação broquidódroma; duas primeiras nervuras partindo da base do folíolo; pecíolo 0,9-2,6 cm compr., descamante, glabro. Inflorescências em tirsos; cálice campanulado, pubérulo a subtomentoso, 5-lobado, lobos apiculados, $0,2 \mathrm{~cm}$ compr.; corola lilás, interior do tubo amarelo, $3,2 \times 5,7 \mathrm{~cm}$; estames inclusos. Cápsulas lineares, alongadas, $17-32 \mathrm{~cm}$ compr.

Material selecionado: BRASIL. São PaUlo: São Paulo, Parque Estadual das Fontes do Ipiranga, 28-XI-1980, M.S.F. Silvestre 253 (SP).

Observações: espécie citada como Dolichandra unguiculata (Vell.) L.G. Lohmann no Catálogo de las Plantas Vasculares del Cono Sur (Arbo \& Lohmann 2008) e no Catálogo de Plantas e Fungos do Brasil (Lohmann 2010), porém não foi ainda validamente publicada.

6.15. Pithecoctenium dolichoides (Cham.) Bureau exK. Schum. in H.G.A. Engler \& K.A.E. Prantl, Nat. Pflanzenfam. 4(3b): 218. 1894

Trepadeira lenhosa, preensil; gavinha 15-ramificada, unhas e discos ausentes. Ramos 6-8 angulosos, lanosos. Folhas 2-3 folioladas, opostas; lâmina 9-11 × 4,5-6,5 cm, oval, pubescente; ápice agudo; base cordada; venação actinódroma basal; pecíolo 1,5-2,5 cm compr.; peciólulo 0,8-1,2 cm compr. Inflorescências em racemos decussados, lanosas; cálice cupuliforme, denticulado, pubérulo a tomentoso, ca. 1,3 cm compr.; corola tubular-campanulada, alva, pubescente externamente; ca. $6,5 \mathrm{~cm}$ compr.; estames inclusos. Cápsulas lineares, muricadas.

Material selecionado: BRASIL. São Paulo: São Paulo, Parque Estadual das Fontes do Ipiranga, W. Hoehne 1532 (SPF); São Paulo: São Paulo, Jardim Botânico de São Paulo, 20-I-1940, O. Handro s.n. (SP33259). 
Observações: espécie citada como Amphilophium dolichoides no Catálogo de las Plantas Vasculares del Cono Sur (Arbo \& Lohmann 2008) e no Catálogo de Plantas e Fungos do Brasil (Lohmann 2010), porém não foi ainda validamente publicada.

\subsection{Pleonotoma tetraquetra (Cham.) Bureau, J. Soc. Imp. Centr. Hort. 2: 156. 1868.}

Trepadeira lenhosa, preensil; gavinha trífida, unhas e discos ausentes. Ramos 4-angular, dendróide-pubescentes. Folhas 2-ternadas, opostas; lâmina 8-9 × 4,5-5,5 cm, oval a oboval, ferrugínea, dendróide-pubescente; ápice obtuso a arredondado; base arredondada a atenuada; venação eucamptódroma; pecíolo ca. $3 \mathrm{~cm}$ compr. Inflorescências em racemos; cálice truncado a 5-denteado, pubescente, ca. $1 \mathrm{~cm}$ compr.; corola alva, glandulosa, glabra, $6-7 \mathrm{~cm}$ compr.; estames inclusos. Cápsulas linear-alongadas.

Material selecionado: BRASIL. SÃo PAULO: São Paulo, Butantan, 27-X-1917, F.C. Hoehne s.n. (SP788).

6.17. Pyrostegia venusta (Ker Gawl.) Miers, Proc. Roy. Hort. Soc. 3: 188. 1863.

Figura 14

Trepadeira lenhosa, preensil; gavinha trífida, unhas e discos ausentes. Ramos 6-8-angular, glabros a vilosos, estriados. Folhas 2-3 folioladas, opostas; lâmina 4,5-6,5 × 2,3-3,5 cm, oval a oblongo-lanceolada, glabra a pubérula; ápice obtuso a acuminado; base arredondada; venação broquidódroma; pecíolo 1,5-2,5 cm compr.; peciólulo 0,8-1,2 cm compr. Inflorescências em panículas a corimbos; cálice campanulado, subtruncado, lepidoto, margens ciliadas, ca. 0,5 cm compr.; corola alaranjada a amarela, prefloração valvar, glabra externamente, lobos pubérulos a lanosos, 5,6-6,5 cm compr.; estames exsertos. Cápsulas linear-alongadas, achatadas, 25-30 cm compr.

Material selecionado: BRASIL. São Paulo: São Paulo, Jardim Botânico, 21-VIII-1931, F.C. Hoehne s.n. (SP28148).

6.18. Stizophyllum perforatum (Cham.) Miers, Proc. Roy. Hort. Soc. 3: 198. 1863.

Figura 15

Trepadeira lenhosa, preensil; gavinha simples. Ramos achatados, fistulosos, tomentosos a vilosos quando jovens. Folhas 2-3 folioladas, opostas; lâmina
6-8 $\times$ 3-5 cm, oblonga a oblongo-lanceolada; face adaxial pubescente; ápice agudo; base arredondada; venação eucamptódroma; pecíolo 2-3 cm compr.; peciólulo 1-2,5 cm compr. Inflorescências em racemos axilares, paucifloras; cálice amplo, inflado, pubescente, glanduloso, 5-lobado, ca. 1,3 cm compr.; corola rósea; pubérula e glandulosa externamente, margens dos lobos pubescentes, ca. 4,5 cm compr.; estames inclusos. Cápsulas alongadas, pubescentes, 40-47 cm compr.

Material selecionado: BRASIL. São Paulo: São Paulo, Parque Estadual das Fontes do Ipiranga, 15-III-2006, B.L.P. Villagra 41 (SP); 2-II-2006, B.L.P. Villagra 212 (SP).

6.19. Tanaecium pyramidatum (Rich.) L.Lohmann, Nuevo Cat. Fl. Vasc. Venezuela 273. 2008.

Trepadeira lenhosa, preensil; gavinha trífida, uncinada. Ramos cilíndricos, glabros, estriados, lenticelados. Folhas 2-3 folioladas, opostas; lâmina 7-9 × 2,5-4 cm, oblonga a subelíptica, glabra; ápice agudo a obtuso; base simétrica atenuada; venação eucamptódroma; pecíolo glabro; 1-2 cm compr.; peciólulo 0,8-1,2 cm compr., glabro. Inflorescências em subcorimbos, terminais; cálice cupular, subinflado, truncado, glabro, 0,5-0,7 cm compr.; corola rósea a arroxeada, tomentosa externamente, $3-4,5 \mathrm{~cm}$ compr.; estames inclusos. Cápsulas lineares, $32-38 \mathrm{~cm}$ compr.

Material selecionado: BRASIL. São Paulo: São Paulo, Parque Estadual das Fontes do Ipiranga, B.L.P. Villagra 76 (SP).

6.20. Tynanthus elegans (Cham.) Miers, Proc. Roy.Hort. Soc. 3: 193. 1863.

Trepadeira lenhosa, preensil; gavinha trífida, unhas e discos ausentes. Ramos cilíndricos, pubescentes quando jovens, não descamantes. Folhas 2 folioladas, opostas; lâmina 5-7 × 2-2,7 cm, elíptica a obovada, discolor; face adaxial pubescente; face abaxial pubérula; ápice agudo; base atenuada a pouco arredondada; venação eucamptódroma; pecíolo e peciólulo 1-1,5 cm compr. Inflorescências em panículas axilares; cálice truncado, denticulado, ca. $0,3 \mathrm{~cm}$ compr.; corola alva, pubescente externamente, ca. $0,8 \mathrm{~cm}$ compr.; estames inclusos. Cápsulas lineares.

Material selecionado: BRASIL. São Paulo: São Paulo, Jardim Botânico de São Paulo, 15-I-1938, O. Handro s.n. (SP43041). 


\section{BORAGINACEAE}

7.1. Tournefortia breviflora DC., Prodr. 9: 520. 1845.

Trepadeira lenhosa, volúvel. Ramos glabros. Folhas simples, alternas; lâmina 2-8 × 1-3,5 cm, oval-lanceolada, levemente assimétrica; glabras a pubérulas; ápice longo-acuminado; margem inteira; base arredondada, obtusa ou cuneada, levemente oblíqua; venação eucamptódroma; pecíolo 0,3-0,6 cm compr. Inflorescências em cimeiras escorpióides; flores ca. $0,3 \mathrm{~cm}$ compr.; cálice ca. $0,1 \mathrm{~cm}$ compr., pubecente; corola pilosa externamente, lobos linear-lanceolados, tubo ca. 0,1 cm compr. Drupas lobadas.

Material selecionado: BRASIL. São Paulo: São Paulo, Parque Estadual das Fontes do Ipiranga, 4-VII-2006, B.L.P. Villagra 103 (SP).

7.2. Tournefortia villosa Salzm. ex DC., Prodr. 9: 524. 1845.

Trepadeira lenhosa, volúvel. Ramos tomentosos densamente. Folhas simples, alternas; lâmina 4-8,5 × 2-4,5 cm, oval, levemente assimétrica; face adaxial tomentosa; face abaxial viloso-tomentosa; ápice agudo a acuminado; margem inteira; base arredondada ou obtusa; venação eucamptódroma; pecíolo 0,8-1,2 cm compr. Inflorescências em cimeiras escorpióides; flores ca. $0,5 \mathrm{~cm}$ compr.; cálice ca. $0,2 \mathrm{~cm}$ compr., pubescente; corola pilosa externamente, lobos linear-lanceolados. Drupas 4-lobadas.

Material selecionado: BRASIL. São Paulo: São Paulo, Parque Estadual das Fontes do Ipiranga, 3-V-1979, M.M.R. Fiuza de Melo 295 (SP).

\section{CACTACEAE}

8.1. Pereskia aculeata Mill., Gard. dict., ed. 8. 1768. Figura 16

Trepadeira lenhosa, escandente. Ramos glabros, estrias longitudinais, armados; espinhos curvos em aréolas. Folhas simples, alternas; lâmina 3-5 × 2-3 cm, lanceolada, cartácea, glabra, rugosa quando seca; ápice acuminado; base arredondada; venação eucamptódroma; pecíolo 0,5-0,7 cm compr. Inflorescências em panículas, terminais, até 70 flores; brácteas suculentas; cálice pubescente; corola alva. Bagas solitárias ou agrupadas.

Material selecionado: BRASIL. SÃo PAULO: São Paulo, Jardim Botânico, 5-X-2006, B.L.P. Villagra 163 (SP).

Ilustração em Zappi et al. (2007).
8.2. Pereskia grandifolia Haw., Revis. Pl. Succ.: 85. 1821.

Trepadeira lenhosa, escandente. Ramos glabros, armados; espinhos retos em aréolas. Folhas simples, alternas; lâmina 8-11 × 2-5 cm, oblonga, membranácea, glabra, rugosa quando seca; ápice acuminado; base aguda; venação eucamptódroma; pecíolo 0,5-1 cm compr. Inflorescências em panículas, terminais; flores 10-15; bractéolas foliáceas, suculentas; cálice tomentoso; corola rósea. Bagas agrupadas.

Material selecionado: BRASIL. São Paulo: São Paulo, Parque Estadual das Fontes do Ipiranga, 29-III-1977, M. Kirizawa \& M. Goes 320 (SP).

Ilustração em Zappi et al. (2007).

\section{CELASTRACEAE}

9.1. Hippocratea volubilis L., Sp. pl. 2: 1191. 1753.

Trepadeira lenhosa, volúvel; látex ausente. Ramos lenticelados, glabros. Folhas simples, opostas; lâmina 6,5-9,5 × 2,3-3,7 cm, oval, glabra; cartácea; ápice agudo; margem serreada; base obtusa; venação eucamptódroma; estípulas ausentes; nectários ausentes; pecíolo 0,8-1,2 cm compr., canaliculado na face adaxial, glabro. Inflorescências em cimeiras; flores 5-6 mm diâm.; corola rotácea; pétalas deflexas, creme-esverdeadas, disco pulviniforme, pubérulas internamente. Cápsulas esquizocárpicas, mericarpos $3,4,5-6 \times 2,1-2,8 \mathrm{~cm}$. Sementes aladas.

Material selecionado: BRASIL. SÃo PaUlo: São Paulo, Jardim Botânico de São Paulo, 16-XII-1931, F.C. Hoehne s.n. (SP28607).

Ilustração em Lombardi \& Lara (2003).

9.2. Peritassa hatschbachii Lombardi, Novon 9(2): 222. 1999.

Trepadeira lenhosa, volúvel; látex ausente. Ramos lenticelados, glabros. Folhas simples, opostas; lâmina 3-8,5 × 1,1-4,4 cm, elíptica, raramente oblonga, glabra, cartácea; ápice agudo; margem inteira; base cuneada; venação broquidródoma; estípulas ausentes; nectários ausentes; pecíolo 4-7 mm compr.; canaliculado na face adaxial; glabro. Inflorescências em panículas; flores 3,1-4,4 mm diâm.; corola campanulada, amarela; disco nectarífero tubular. Drupas globosas, 1,7-2 cm diâm. 
Material selecionado: BRASIL. São Paulo: São Paulo, Parque Estadual das Fontes do Ipiranga, 20-I-1932, F.C. Hoehne s.n. (SP28732).

Ilustração em Lombardi \& Temponi (1999).

\subsection{Pristimera celastroides (Kunt.) A.C. Sm., Brittonia} 3(3): 371. 1940.

Trepadeira lenhosa, volúvel; látex ausente. Ramos glabros. Folhas simples, opostas ou subopostas; lâmina 5-10,2 × 2,5-3,8 cm, elípticas, glabras, cartáceas, verdes quando secas; ápice agudo, levemente emarginado; margem crenulada; base cuneada; venação secundária imersa; pecíolo $0,4-1,3 \mathrm{~cm}$ compr. Inflorescências em panículas corimbiformes, axilares; flores 2,5-3,7 mm diâm.; corola rotácea, creme-esverdeada; disco anuliforme, levemente pentagonal. Cápsulas esquizocárpicas, mericarpos 3, elípticos, 2,6-5 × 1,5-3,6 cm. Sementes aladas.

Material selecionado: BRASIL. SÃo PaUlo: São Paulo, Jardim Botânico de São Paulo, 28-X-1937, O. Handro s.n. (SP43043).

Ilustração em Lombardi \& Lara (2003).

\subsection{Salacia elliptica (Mart. ex Schult.) G. Don, Gen.hist.}

\section{1: 628.1831.}

Trepadeira lenhosa, volúvel; látex ausente. Ramos glabros, resina vermelha. Folhas simples, opostas ou subopostas; lâmina 5,7-14 × 1,6-5 cm, elíptica; glabra, cartácea, ápice agudo; margem inteira a levemente crenulada; base cuneada; venação secundária imersa em ambas as faces; estípulas ausentes; nectários ausentes; pecíolo 0,5-1 cm compr. Inflorescências em fascículos, axilares; flores 7,5-11,7 mm diâm.; corola rotácea, creme-esverdeada; disco nectarífero piriforme. Drupas subpiriformes ou globóides, alaranjadas. Sementes fusiformes.

Material selecionado: BRASIL. São Paulo: São Paulo, Reserva Biológica, Parque Estadual das Fontes do Ipiranga, entre a Vila Fachini e Campanário, 10-X-1979, M.R.F. Melo 143 (SP).

Ilustração em Lombardi \& Lara (2003).

9.5. Tontelea miersii (Peyr.) A.C. Sm., Brittonia 3: 487. 1940.

Trepadeira lenhosa, volúvel; látex ausente. Ramos glabros. Folhas simples, opostas ou subopostas, lâmina 7,5-11,5 × 1,8-3,4 cm, elíptica, glabra, cartácea; ápice agudo, margem inteira, base cuneada; venação secundária imersa; pecíolo $1-1,5 \mathrm{~cm}$ compr. Inflorescências em cimeiras, axilares; flores 1,5-3 mm diâm.; corola campanuliforme, creme-esverdeada; pétalas farinoso-pubérulas; disco tubular. Drupas elipsóides ou piriformes, enegrecidas quando secas.

Material selecionado: BRASIL. São PAUlo: São Paulo, Jardim Botânico de São Paulo, VIII-1944, M. Kuhlmann s.n. (SP47401).

\section{CONVOLVULACEAE}

10.1. Convolvulus crenatifolius Ruiz \& Pav., Fl. Peruv. 2: 10.1799.

Trepadeira herbácea, volúvel. Ramos tomentosos, tricomas translúcidos. Folhas simples, alternas, inteiras; lâmina 3-4 × 2-3 cm, sagitado-oblonga, tomentosa; ápice obtuso, mucronado; margem sinuada; base cordada; venação actinódroma. Inflorescências em cimeiras axilares; brácteas filiformes; sépalas externas coriáceas, obovadas, margem escariosa, ápice apiculado; sépalas internas pubérulas, margem ciliada; corola infundibuliforme, alva ou rósea, interplica vilosa; anteras rimosas. Cápsulas ovóides, sépalas persistentes.

Material selecionado: BRASIL. São Paulo: São Paulo, Jardim Botânico, 20-XI-1938, O. Handro s.n. (SP43040).

10.2. Ipomoea alba L., Sp. pl. 1: 161. 1753.

Trepadeira herbácea, volúvel. Ramos lisos, acúleos curtos, carnosos, glabros. Folhas simples, alternas, inteiras ou 2-5 lobadas; lâmina 7-9 × 6-8 cm, oval-orbiculada, glabra; ápice agudo; base cordada; venação actinódroma. Inflorescências em cimeiras axilares; flores 5-meras; sépalas carnosas, ovais ou elípticas, aristas apicais nas sépalas externas; corola hipocrateriforme, alva, tubo 9-15 cm compr.; anteras rimosas. Cápsulas globosas ou ovóides.

Material selecionado: BRASIL. São PAULO: São Paulo, Parque Estadual das Fontes do Ipiranga, 25-XI-1980, N.A. Rosa \& J.M. Pires 3838 (SP).

Ilustração em Simão-Bianchini (1998).

10.3. Ipomoea aristolochiaefolia (H.B.K.) G. Don., Gen Syst. 4: 277. 1838.

Trepadeira herbácea, volúvel. Ramos pubérulos, tricomas translúcidos. Folhas simples, alternas, 
3-lobadas; lâmina 3-5 × 2,5-4 cm, deltóide; faces adaxial e abaxial pubérulas; ápice mucronado; base cordada; venação actinódroma. Inflorescências em cimeiras axilares, multifloras; flores 5-meras; sépalas oval-lanceolada, ápice agudo, margem pubescente; corola infundibuliforme, rósea ou vermelha, fauce mais escura, 2-2,5 cm compr.; anteras rimosas. Cápsulas ovóides. Sementes escuras, pubescentes.

Material selecionado: BRASIL. São Paulo: São Paulo, Parque Estadual das Fontes do Ipiranga, 2-IV-1974, J.S. Silva s.n. (SP122731).

Ilustração em Simão-Bianchini (1998).

10.4.Ipomoea cairica(L.) Sweet, Hort. brit. 1:287.1827. Figura 17

Trepadeira herbácea, volúvel. Ramos estriados, glabros. Folhas simples, alternas, 5-lobadas; estruturas foliáceas nas axilas; lâmina 3-4×1-1,7 cm, membranácea; face adaxial espiculada nas margens; face abaxial glabra; venação palinactinódroma. Inflorescências em cimeiras axilares; flores 5-meras; sépalas subiguais, membranáceas, glabras; corola infundibuliforme, lilás, 3-6 cm compr.; anteras rimosas. Cápsulas globosas, glabras. Sementes cuneiformes, pubescentes no dorso.

Material selecionado: BRASIL. São PaUlo: São Paulo, Parque Estadual das Fontes do Ipiranga, 22-II-2006, B.L.P. Villagra 51 (SP).

Ilustração em Simão-Bianchini (1998).

10.5. Ipomoea indica (Burm.) Merr., Interpr. Herb. Amboin.: 415. 1917.

Figura 18

Trepadeira herbácea, volúvel. Ramos pubescentes, tricomas adpressos, amarelo-translúcidos. Folhas simples, alternas, inteiras a 3-lobadas; lâmina 5,5-6,5 × 4,5-6 cm, cordada, pubescente, tricomas alvotranslúcidos; ápice acuminado; base cordada; venação actinódroma basal. Inflorescências em cimeiras axilares, paucifloras, geralmente 2 flores; flores 5-meras; sépalas lanceoladas a oblongo-lanceoladas, tricomas adpressos, amarelo-translúcidos na face externa; corola infundibuliforme, purpúrea, fauce alva, 4-7,5 cm compr.; anteras rimosas.

Material selecionado: BRASIL. São PAUlo: São Paulo, Parque Estadual das Fontes do Ipiranga, 8-III-2006, B.L.P. Villagra 35 (SP).
10.6. Ipomoea purpurea (L.) Roth., Bot. Abh.: 27. 1787.

Trepadeira herbácea, volúvel. Ramos hirsutos, tricomas translúcidos. Folhas simples, alternas, inteiras ou 3-lobadas; lâmina 5-6 × 5,5-6,5 cm, largamente cordada, pubescente em ambas as faces, ápice agudo; base cordada; venação actinódroma. Inflorescências em cimeiras axilares, 2-5 flores; flores 5-meras; sépalas oblongo-lanceoladas, tricomas bulbosos na porção basal; corola infundibuliforme, purpúrea, azul, rósea ou alva, 3-6 cm compr.; anteras rimosas.

Material selecionado: BRASIL. São Paulo: São Paulo, Parque Estadual das Fontes do Ipiranga, 4-V-1982, C.R.F. Guedes et al. s.n. (SP194607).

10.7. Ipomoea saopaulista O'Donell, Lilloa 26: 392. 1953.

Figura 19

Trepadeira herbácea, volúvel. Ramos pubescentes, indumento translúcido. Folhas simples, alternas, inteiras; lâmina 6-8 × 7-8 cm, oval, orbiculada; face adaxial pubescente; face abaxial tomentosa; ápice agudo a mucronado; base cordada; venação eucamptódroma. Inflorescências em cimeiras axilares; pedúnculo 3-6 cm compr.; flores 5-meras; sépalas elípticas, subiguais, ápice retuso a obtuso, glabras; corola infundibuliforme, alva, glabra; anteras rimosas. Cápsulas globosas ou ovóides.

Material selecionado: BRASIL. São PAUlo: São Paulo, Parque Estadual das Fontes do Ipiranga, 9-II-2006, B.L.P. Villagra 67 (SP).

Ilustração em Simão-Bianchini (1998).

10.8. Ipomoea triloba L., Sp. pl. 1: 161. 1753.

Trepadeira herbácea, volúvel. Ramos pubescentes, tricomas simples alvo-translúcidos. Folhas simples, alternas, 3-lobadas, cordadas, lobos laterais obtusos ou ligeiramente agudos; lobo central mucronado; lâmina 3-4 × 5-6 cm; glabra ou pubescente; ápice agudo; base cordada; venação actinódroma. Inflorescências em cimeiras axilares; flores até 7, 5-meras; sépalas oval-lanceoladas, ápice acuminado, pubescentes nas margens e dorso; corola infundibuliforme, alva ou rósea, 1,8-2,5 cm compr.; anteras rimosas. Cápsulas subglobosas, apiculadas, glabras.

Material selecionado: BRASIL. São PAUlo: São Paulo, Parque Estadual das Fontes do Ipiranga, 2-IV-1974, J.S. Silva 260 (SP). 

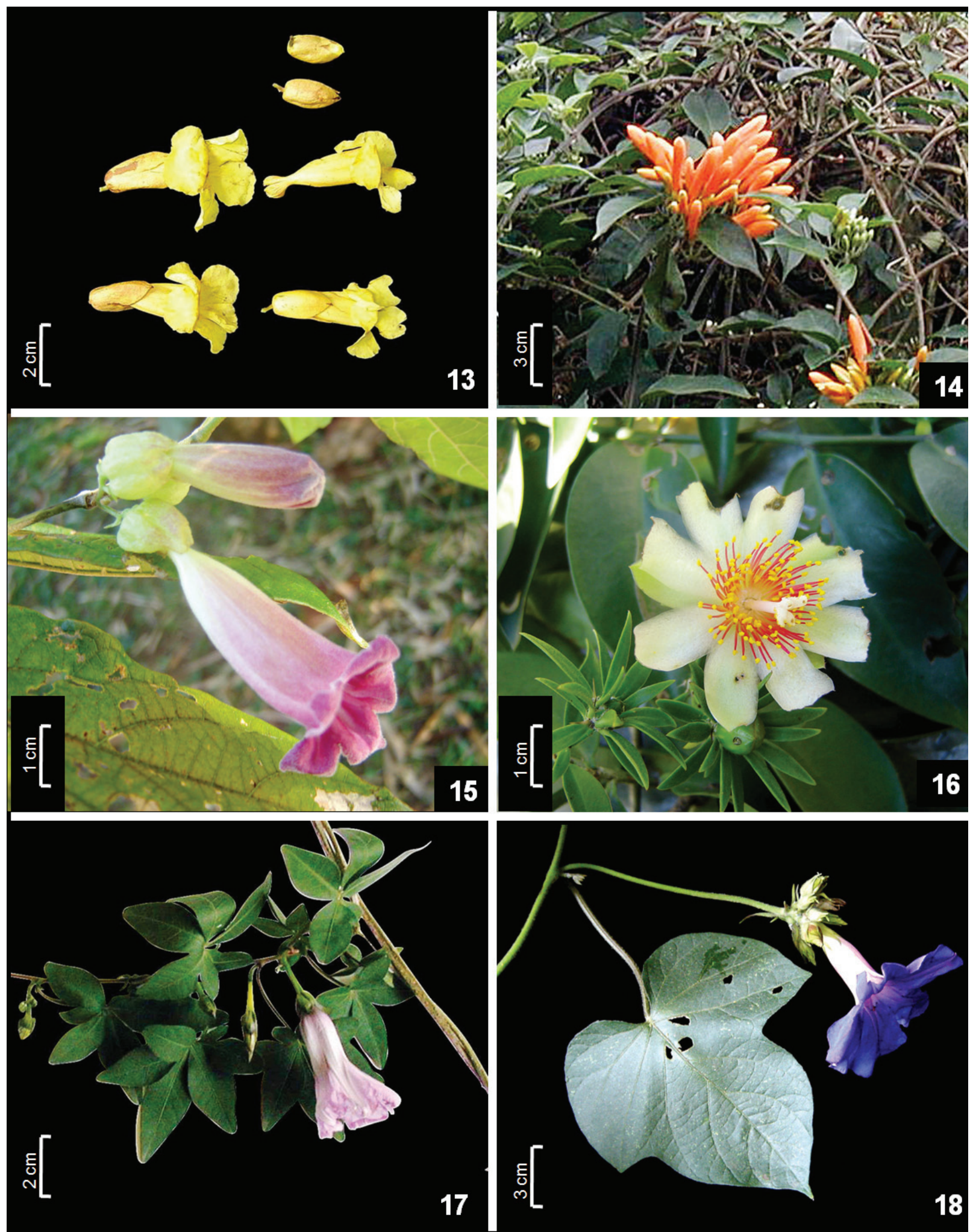

Figura 13-18. Bignoniaceae. 13. Mansoa difficilis. 14. Pyrostegia venusta. 15. Stizophyllum perforatum. Cactaceae. 16. Pereskia aculeata. Convolvulaceae. 17. Ipomoea cairica. 18. Ipomoea indica.

Figure 13-18. Bignoniaceae. 13. Mansoa difficilis. 14. Pyrostegia venusta. 15. Stizophyllum perforatum. Cactaceae. 16. Pereskia aculeata. Convolvulaceae. 17. Ipomoea cairica. 18. Ipomoea indica. 
10.9. Jacquemontia ferruginea Choisy, Mém. Soc. Phys. Genève 8: 139.1838.

Trepadeira herbácea, volúvel. Ramos tomentosos-ferrugíneos; tricomas simples, bifurcados a trifurcados. Folhas simples, alternas; lâmina 4-5,5 × 2-2,5 cm, oval-lanceolada, pubescente; tricomas bifurcados a trifurcados em ambas as faces, as jovens densamente tomentosas; ápice agudo a mucronado; base obtusa a cordada; venação eucamptódroma. Inflorescências em cimeiras axilares; dicásio composto, 2 brácteas foliáceas na bifurcação do dicásio; brácteas linear-lanceoladas menores que as primeiras, tomentosas; pedúnculo até $20 \mathrm{~cm}$ compr.; sépalas lanceoladas, ápice longo-acuminado, tomentosas; corola infundibuliforme, azul, glabra; anteras rimosas. Cápsulas subglobosas, glabras, cálice persistente.

Material selecionado: BRASIL. São Paulo: São Paulo, Parque Estadual das Fontes do Ipiranga, 10-VII-2005, B.L.P. Villagra 25 (SP).

\subsection{Merremia macrocalyx (Ruiz \& Pav.) O'Donell,} Lilloa 6: 506. 1941.

Figura 20

Trepadeira herbácea, volúvel. Ramos hirsutos ou glabros. Folhas simples, alternas, 5-7 lobadas; lobos oblongos; lâmina 10-12 × 7,5-8,5 cm; face adaxial hirsuta; face abaxial velutina; ápice acuminado; margem inteira; base atenuada; venação palinactinódroma. Inflorescências em panículas axilares; multifloras; sépalas 2-2,5 cm compr., obtusas ou agudas; glabras; corola infundibuliforme, alva, linhas escuras nas interplicas, glabra; anteras rimosas. Cápsulas globosas, glabras, cálice persistente.

Material selecionado: BRASIL. São Paulo: São Paulo, Parque Estadual das Fontes do Ipiranga, 23-III-2007, B.L.P. Villagra 187 (SP).

\subsection{Odonellia eriocephala (Moric.) K.R. Robertson,} Brittonia 24(4): 421. 1982.

Figura 21

Trepadeira herbácea, volúvel. Ramos seríceos a pubescentes, esbranquiçado. Folhas simples, alternas, inteiras; lâmina 6-8,5 × 4-6 cm, oval-orbiculada, tricomas seríceos, castanho-dourados em ambas as faces; ápice acuminado; base obtusa; venação eucamptódroma. Inflorescências em capítulos; pedúnculo 10-15 cm compr.; brácteas ovais a oval-lanceoladas, ápice acuminado, densamente seríceas; sépalas elípticas a lanceoladas, ápice acuminado, denso-seríceas; corola infundibuliforme, alva, interplicas vilosas; anteras rimosas. Cápsulas.

Material selecionado: BRASIL. São Paulo: São Paulo, Parque Estadual das Fontes do Ipiranga, 27-VII-2005, B.L.P. Villagra 21 (SP).

\section{CUCURBITACEAE}

11.1. Cayaponia cabocla (Vell.) Mart., Syst. Mat. Med. Brasil: 81. 1843.

Trepadeira herbácea, preensil; gavinha axilar, 2-3 ramificada, na base do pecíolo formando ângulo de $90^{\circ}$; monóica. Ramos sulcados, pubescentes. Folhas simples, alternas, inteiras, 3-lobadas; lâmina 4-17 × 3-24 cm, lobo oval, margem lisa, membranácea, pubescente; venação actinódroma basal. Flores díclinas; estaminadas solitárias, díades ou tríades; pedicelo 1-5 cm compr.; hipanto 1,7-1,9 cm compr.; sépalas pubescentes, 6-8 mm compr.; pétalas papilosas, 4-6 mm compr.; conectivo glabro; pistilódio obscuro. Flores pistiladas solitárias; pedicelo 1-2 cm compr.; hipanto 1-1,5 cm compr.; sépalas pubescentes, 2-3 mm compr.; pétalas papilosas, 6-7 $\mathrm{mm}$ compr.; estaminódios glabros. Pepônios globosos, jovens verdes, quando maduros vermelhos a vináceos, membranáceos, pubérulos, 2,5-3,5 cm diâm. Sementes ovadas, 6-12, escuras, com pleurograma.

Material selecionado: BRASIL. São PAUlo: São Paulo, Jardim Botânico de São Paulo, 25-III-1933, F.C. Hoehne s.n. (SP30526).

Ilustração em Klein (2000).

11.2. Cayaponia martiana (Cogn.) Cogn. in DC., Monogr. Phan. 3: 777. 1881.

Trepadeira herbácea, preensil; gavinha axilar, 3-ramificadas, formando ângulo de $90^{\circ}$; monóica. Ramos sulcados, pubescentes. Folhas simples, alternas, inteiras, 3-5 lobadas; lâmina 7-17 × 8-20 cm, lobos oblongos, membranácea, tomentosa; venação actinódroma basal. Flores díclinas; estaminadas em panículas; pedicelo 3-4 mm compr.; hipanto ca. $3 \mathrm{~mm}$ compr.; sépalas ca. 0,5 mm compr.; pétalas papilosas, 4-5 mm compr.; conectivo glabro; pistilódio 3-lobado. Flores pistiladas em panículas; pedicelo 4-5 mm compr.; hipanto 5-7 $\mathrm{mm}$ compr.; sépalas glabras, ca. $0,5 \mathrm{~mm}$ compr.; pétalas papilosas, 2-3 mm compr.; estaminódios glabros. Pepônios 
globosos, jovens verdes, 10 manchas longitudinais verde-escuras, quando maduros vermelhos, 10 manchas longitudinais pretas, membranáceos, pubérulos, 0,8-1,1 cm diâm. Sementes 1-3, pardas, manchas escuras, sem pleurograma.

Material estudado: BRASIL. São PAULo: São Paulo, Parque Estadual das Fontes do Ipiranga, 26-III-1985, C.B.Toledo et al. 82 (SP).

Ilustração em Klein (2000).

11.3. Cayaponia pilosa (Vell.) Cogn. in Mart., Fl. bras. 6(4): 75.1878.

Trepadeira herbácea, preensil; gavinha axilar, 2-ramificada, formando ângulo de $90^{\circ}$; monóica. Ramos cilíndricos, pubescentes. Folhas simples, alternas, inteiras a 3-5 lobadas; lâmina 8-12 × 8-9 cm, lobos lanceolados, membranácea, pubescente; venação actinódroma basal. Flores díclinas; estaminadas solitárias, axilares; pedicelo 7-9 cm compr.; hipanto 1-2 cm compr.; sépalas 1,5-3 cm compr.; pétalas 1,7-2 cm compr.; conectivo pubescente; pistilódio cupuliforme. Flores pistiladas 1-2, axilares; pedicelo 2-4 cm compr.; hipanto viloso; 1,6-2,9 cm compr.; sépalas 5-7 mm compr.; pétalas tomentosas; $0,8-1$ cm compr.; estaminódios vilosos na porção mediana. Pepônios elipsóides, jovens verdes, quando maduros vináceos, membranáceos, pubérulos, $2-4 \times 1,5-2,5 \mathrm{~cm}$. Sementes rômbicas, 6-12, castanhas, sem pleurograma.

Material selecionado: BRASIL. São Paulo: São Paulo, Jardim Botânico de São Paulo, 20-I-1938, O. Handro, s.n. (SP39418).

Ilustração em Klein (2000).

11.4. Cayaponia villosissima Cogn. in Mart., Fl. bras. 6(4): 81, t. 24.1878.

Figura 22

Trepadeira herbácea, preensil; gavinha axilar, 3-ramificadas, formando ângulo de $90^{\circ}$; monóica. Ramos estriados, cilíndricos, densamente vilosos. Folhas simples, alternas, 3 lobadas; lâmina 9-14 × 7-9 cm, lanceolada, vilosa, membranácea; ápice agudo a acuminado; base arredondada; venação actinódroma basal. Flores díclinas; estaminadas em racemos, amarelas; pedicelo 0,52 cm compr.; hipanto viloso, 1-1,1 cm compr.; sépalas vilosas, 6-7 $\mathrm{mm}$ compr.; pétalas papilosas,
3-4 mm diâm.; conectivo tomentoso; pistilódio ausente. Flores pistiladas em racemos; pedicelo 1-3 mm compr.; hipanto viloso, 6-7 mm compr.; sépalas 7-8 mm compr.; pétalas vilosas, 2-3 mm compr. Pepônios globosos, verde-amarelados, membranáceos, vilosos, 9-11 × 7-8 mm. Sementes ovais, 6-12.

Material selecionado: BRASIL. São PAulo: São Paulo, Parque Estadual das Fontes do Ipiranga, 8-III-2006, B.L.P. Villagra 33 (SP).

11.5. Echinopepon racemosus (Steud.) C. Jeffrey, Kew Bulletin 33(2): 357. 1978.

Trepadeira herbácea, preensil; gavinha axilar, 3-ramificada, formando ângulo de $90^{\circ}$; monóica. Ramos sulcados, pubescentes. Folhas simples, alternas, inteiras a 3-lobadas; lâmina 8-12 ×4-8 cm, lobos ovados a triangulares, estrigosa, margem lisa, membranácea; venação actinódroma. Flores díclinas; estaminadas em racemos; pedicelo 5-10 mm compr.; hipanto campanulado, viloso, 4-5 mm compr.; sépalas lanceoladas, vilosas, 2-3 mm compr.; pétalas ovadas, 4-5 mm compr.; conectivo glabro; pistilódio ausente. Flores pistiladas isoladas ou geminadas, axilares; pedicelo 2-5 mm compr.; hipanto aculeado; constrito no terço médio superior, viloso, $2-4 \mathrm{~cm}$ compr.; sépalas lineares, vilosas, 2-3 $\mathrm{mm}$ compr.; pétalas lanceoladas, vilosas, 5-6 mm compr.; estaminódios ausentes. Pepônios elipsóides, amarelos, secos, aculeados, $4-5 \times 1-2 \mathrm{~cm}$. Sementes ovais, não aladas, muitas.

Material selecionado: BRASIL. São Paulo: São Paulo, Parque Estadual das Fontes do Ipiranga, área de Diadema, 9-III-1976, M. Sakane 437 (SP).

11.6. Fevillea passiftora Vell., Fl. Flumin. Icon. 10: 104. 1827.

Figura 23

Trepadeira herbácea, preensil; gavinha axilar, 2-ramificada, formando ângulo de $90^{\circ}$; monóica. Ramos cilíndricos. Folhas simples, alternas, inteiras; lâmina 3-10 × 1,5-5 cm, oval-oblonga; pubérula, um par de glândulas na base; venação actinódroma basal, 3-nervada. Flores díclinas; estaminadas em racemos; pedicelo pubérulo; hipanto campanulado; pubescente; sépalas triangulares, glabras na face abaxial, densamente tomentosas na face adaxial; 2-3 $\mathrm{mm}$ compr.; pétalas oblongo-lanceoladas, 3-5 mm compr.; estames 5. Pepônios globosos, glabros,4-10 cm compr. Sementes orbiculares, 18-24, aladas, ca. $4 \mathrm{~cm}$ compr. 
Material selecionado: BRASIL. São Paulo: São Paulo, Parque Estadual das Fontes do Ipiranga, 23-III-2007, B.L.P. Villagra 194 (SP).

11.7. Melothria cucumis Vell., Fl. flumin. 29. 1825; Icon. 1: 70. 1827.

Trepadeira herbácea, preensil; gavinha simples, axilar, formando ângulo de $90^{\circ}$; monóica. Ramos sulcados, glabros. Folhas simples, alternas, inteiras a 3-5 lobadas; lâmina 3-4 × 4,2-5,2 cm, ovado-cordiforme; face adaxial estrigosa, tricomas brancos ou translúcidos; abaxial glabra; ápice mucronado; margem denteada; base cordada; sinus basal 8-15 × 21-23 mm; venação actinódroma basal; pecíolo 1,8-2,3 cm, estriado, viloso; estípula ausente. Flores díclinas; estaminadas em racemos; pedicelo pubérulo; sépalas triangulares, pubérulas, 0,5-0,8 mm compr.; pétalas oblongo-lanceoladas, 1-1,5 mm compr.; pistilódio inteiro. Flores pistiladas isoladas, axilares; hipanto fusiforme, 1,2-2 cm compr.; sépalas triangulares, pubérulas, ca. $1 \mathrm{~mm}$ compr.; pétalas oblongas-lanceoladas, 1-1,5 mm compr.; estaminódios ausentes. Pepônios oval-oblongos, glabros, 3-4 $\times 2-3 \mathrm{~cm}$. Sementes obovais, amarelas, seríceas.

Material selecionado: BRASIL. São Paulo: São Paulo, Parque Estadual das Fontes do Ipiranga, 3-X1979, S.L. Jung et al. 300 (SP).

11.8. Sicydium gracile Cogn. in Mart., Fl. bras. 6(4): 114. 1878.

Trepadeira herbácea, preensil; gavinha axilar, 2-ramificada, formando ângulo de $90^{\circ}$; monóica. Ramos sulcados, glabros. Folhas simples, alternas, inteiras; lâmina 6-9 × 4,5-5,5 cm, ovada, cordada, glabra, membranácea; ápice acuminado; base auriculada; venação actinódroma basal. Flores díclinas; estaminadas em panículas; pedicelo pubescente, 1-2 mm compr.; hipanto campanulado, 1-2 mm compr.; sépalas lanceoladas, 0,5-1 mm compr.; pétalas ovada-triangulares, 1-1,5 mm compr.; conectivo glabro; pistilódio ausente. Flores pistiladas em panículas; pedicelo glabro, 1-2 mm compr.; hipanto constrito no terço médio superior, viloso, 1,5-2 mm compr.; sépalas lanceoladas, vilosas, 0,5-1 mm compr.; pétalas lanceoladas, glabras, ca. $1 \mathrm{~mm}$ compr.; estaminódios 3. Pepônios globosos, verde-claros a amarelos, glabros, 0,4-0,7 cm compr. Sementes elipsóides, 1.

Material selecionado: BRASIL. São PaUlo: São Paulo, Reserva Biológica, Parque Estadual das Fontes do Ipiranga, 4-IV-1978, M. S. F. Silvestre 101 (SP).
11.9. Sicyos polyacanthos Cogn. in Mart., Fl. bras. 6(4): 107. 1878.

Trepadeira herbácea, preensil; gavinha axilar, 5-ramificada, formando ângulo de $90^{\circ}$; monóica. Ramos sulcados, cilíndricos, glabros. Folhas simples, alternas, 3-5 lobadas; lâmina 6-13 × 12-16 cm, lobos ovados, ovado-suborbicular, tomentosa, membranácea; venação actinódroma basal. Flores díclinas; estaminadas em racemos; pedicelo pubérulo, 2-6 mm compr.; hipanto campanulado, pubescente; sépalas lineares, pubescentes, ca. $1 \mathrm{~mm}$ compr.; pétalas lanceoladas, tomentosas, 3-4 mm compr.; conectivo glabro; pistilódio ausente. Flores pistiladas em fascículos; pedicelo viloso, 1-2 mm compr.; hipanto constrito no terço médio superior, aculeado, 0,6-1,2 cm compr.; sépalas lanceoladas, vilosas, 2-3 mm compr.; pétalas lanceoladas, vilosas, 3-4 mm compr.; estaminódios ausentes. Pepônios fusiformes, amarelos, aculeados, 1-1,5 × 0,3-0,5 cm. Sementes obovais, 1, pleurograma.

Material selecionado: BRASIL. São PAUlo: São Paulo, Jardim Botânico, 18-III-1932, F.C. Hoehne s.n. (SP302780).

\subsection{Wilbrandia verticillata (Vell.) Cogn. in Mart.,} Fl. bras. 6(4): 30. 1878.

Figura 24

Trepadeira herbácea, preensil; gavinha axilar, simples, formando ângulo de $90^{\circ}$; monóica. Ramos lisos, glabros. Folhas simples, alternas, 3-5 lobadas; lâmina 5-18 × 3,5-17 cm, membranácea; face adaxial estrigosa, tricomas brancos ou translúcidos; face abaxial glabra, tricomas nas nervuras; ápice agudo a acuminado; margem denteada; base aguda; venação palinactinódroma; estípulas ausentes; ocelos ausentes; pecíolo sulcado. Flores díclinas; estaminadas em racemos ou espigas, bractéolas lanceoladas; hipanto tubuloso, pubérulo; sépalas ovais, 1,5-3 mm compr.; pétalas ovais, 1,3-2,5 mm compr.; conectivo glabro; pistilódio globoso. Flores pistiladas 2-4, aglomeradas ou fasciculadas; hipanto tubuloso, constrito no terço médio inferior; sépalas lanceoladas, 2-3 mm compr.; pétalas lanceoladas, 1,5-2,5 mm compr.; estaminódios 3-4. Pepônios ovóides, turbinados, jovens verdes, linhas longitudinais verde-escuras, pubérulos, 2-3 $\times 1,5-2 \mathrm{~cm}$. Sementes obovais, muitas, castanhas, tomentosas.

Material selecionado: BRASIL. São Paulo: São Paulo, Parque Estadual das Fontes do Ipiranga, 18-XII-2006, B.L.P. Villagra 151 (SP). 

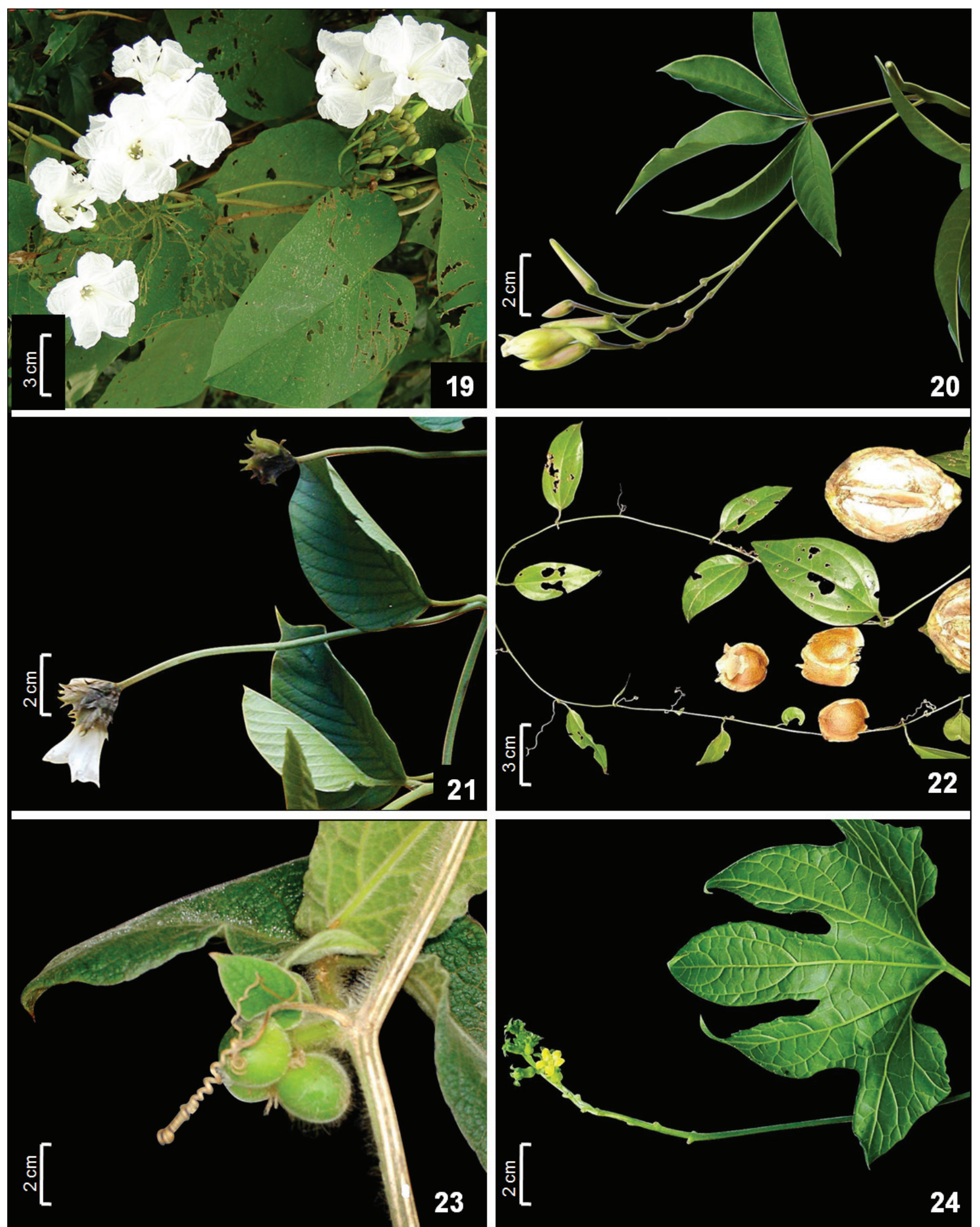

Figura 19-24. Convolvulaceae. 19. Ipomoea saopaulista. 20. Merremia macrocalyx. 21. Odonellia eriocephala. Cucurbitaceae. 22. Fevillea passiflora. 23. Cayaponia villosissima. 24. Wilbrandia verticillata.

Figure 19-24. Convolvulaceae. 19. Ipomoea saopaulista. 20. Merremia macrocalyx. 21. Odonellia eriocephala. Cucurbitaceae. 22. Cayaponia villosissima. 23. Fevillea passiflora. 24. Wilbrandia verticillata. 


\section{DILLENIACEAE}

12.1. Davilla rugosa Poir., Encycl. Suppl. 2: 457. 1812. Figura 25

Trepadeira lenhosa, escandente. Ramos descamantes, vermelho-ferrugíneo, inerme, pubescentes a glabros. Folhas simples, alternas, lâmina $7-13 \times 2-5 \mathrm{~cm}$, ovada a oblonga, membranácea; face adaxial estrigosa; face abaxial pubescente; ápice atenuado; margem serreada; base rotundada; venação craspedódroma. Inflorescências em panículas axilares, $2-5 \mathrm{~cm}$ compr.; cálice verde a vináceo, sépalas 5 , persistentes; pétalas amarelas, 4-6; estames 40-60. Cápsulas globosas, 3-6 mm diâm., cálice persistente.

Material selecionado: BRASIL. São PaUlo: São Paulo, Parque Estadual das Fontes do Ipiranga, 25-V-2007, B.L.P. Villagra 209 (SP).

Ilustrações em Kubitzki \& Reitz (1971).

\subsection{Doliocarpus glomeratus Eichler in Mart., Fl.} bras. 13(1): 74. 1863.

Trepadeira lenhosa, escandente. Ramos descamantes, vermelho-ferrugíneos, glabros. Folhas simples, alternas; lâmina 7,1-14,9 × 3,6-6 cm, oblonga, oboval e elíptica, coriácea; face adaxial glabra; abaxial glabra ou com tricomas na nervura principal, domácias; ápice arredondado, obtuso ou cuspidado; margem inteira; base aguda; venação semi-craspedódroma; pecíolo 1,1-2,2 cm compr., canaliculado na face adaxial, glabro a pubescente. Inflorescências em racemos axilares, 0,5-1 cm compr.; sépalas 4, persistentes; pétalas amarelas, 4-6; estames 50-60, 9-10 mm compr. Bagas globosas, 6-7 mm diâm., vináceas.

Material selecionado: BRASIL. SÃo PAULO: São Paulo, Jardim Botânico, 24-III-1947, M. Kuhlmann 3190 (SP).

\section{DIOSCOREACEAE}

\subsection{Dioscorea dodecaneura Vell., F1. Flum.} 10: 123.1827.

Trepadeira herbácea, volúvel. Ramos estriados, delgados, não alados. Folhas simples, alternas; lâmina 7-15 × 7-17 cm, cordiforme, pubescente, membranácea; pecíolo articulado; ápice caudado; margem não espessada; base cordada; venação actinódroma. Inflorescências femininas em espigas; tépalas pubescentes externamente, glândulas ausentes; estilete 1, 3-partido; estaminódios 6. Cápsulas aladas. Sementes aladas.
Material selecionado: BRASIL. São PAUlo: São Paulo, Parque Estadual das Fontes do Ipiranga, 9-IV1951, W. Hoehne s.n. (SP246861).

13.2. Dioscorea marginata Griseb., F1. bras. 3(1): 37.1842.

Trepadeira herbácea, volúvel. Ramos estriados, delgados, alados. Folhas simples, alternas; lâmina 12-14 × 5,5-8,5 cm, elíptica-oval, glabra, coriácea; ápice apiculado; margem cartilaginosa espessada; base largamente cuneada; venação actinódroma; pecíolo articulado. Inflorescências femininas em espigas; tépalas pubérulas; rudimento de estame. Cápsulas obovais, aladas, 4,5-5,5 cm compr. Sementes oval-oblongas, castanho-escura, aladas.

Material selecionado: BRASIL. São Paulo: São Paulo, Jardim Botânico de São Paulo, 4-V-1934, F.C. Hoehne s.n. (SP31762).

13.3. Dioscorea multiflora Griseb., Fl. bras. 3(1): 35. 1842.

Trepadeira herbácea, volúvel. Ramos estriados, espessados, não alados. Folhas simples, alternas; lâmina 4-5 × 3,5-4,5 cm, cordiforme, glabra, coriácea; ápice longamente acuminado; margem não espessada; base cordada; venação actinódroma; pecíolo articulado. Inflorescências femininas em cacho de espigas; tépalas glabras. Cápsulas elípticas-ovais, 2-2,5 cm compr.

Material selecionado: BRASIL. São Paulo: São Paulo, Parque Estadual das Fontes do Ipiranga, 8-II-1935, F.C. Hoehne s.n. (SP32374).

13.4. Dioscorea olfersiana Klotzsch ex Griseb., Fl. bras. 3(1): 38. 1842.

Figura 26

Trepadeira herbácea, volúvel. Ramos estriados, delgados, alados. Folhas simples, alternas; lâmina 6,5-8,5 × 1,5-2,5 cm, oblongo-lanceolada, glabra, membranácea; ápice acuminado; margem cartilaginosa espessada; base arredondada; venação actinódroma; pecíolo articulado. Inflorescências masculinas em racemos de espigas; tépalas glabras; estames 6 , região mediana do tubo do perigônio. Inflorescências femininas em espigas; tépalas glabras; estaminódios 6. Cápsulas ovais, 1,7-2 cm compr. Sementes ovais, ala circular. 
Material selecionado: BRASIL. São Paulo: São Paulo, Parque Estadual das Fontes do Ipiranga, 5-VI-2007, B.L.P. Villagra et al. 215 (SP).

Ilustração em Kirizawa \& Romanini (2003).

13.5. Dioscorea subhastata Vell., Fl. flum. Icon. 10: 121. 1827.

Trepadeira herbácea, volúvel. Ramos estriados, delgados, não alados. Folhas simples, alternas; lâmina 5-8 × 4-6 cm, cordiforme, híspida, membranácea; ápice longamente acuminado; margem não espessada; base cordada; venação actinódroma; pecíolo articulado. Inflorescências masculinas em racemos; tépalas patentes, glabras; coluna estaminal cilíndrica, vinácea. Inflorescências femininas em espigas; tépalas reflexas; glabras; glândulas ausentes; estilete 3, unicinados; estaminódios. Cápsulas oblongas, 1,3-2,5 cm compr. Sementes aladas.

Material selecionado: BRASIL. SÃo Paulo: São Paulo, Parque Estadual das Fontes do Ipiranga, 16-II-1978, M. Kirizawa 178 (SP).

Ilustração em Xifreda \& Kirizawa (2003).

\section{EUPHORBIACEAE}

\subsection{Dalechampia triphylla Lam., Encycl. 2:} 258. 1786.

Figura 27

Trepadeira herbácea, volúvel; monóica. Ramos pubescentes. Folhas alternas; 3 folioladas; lâmina 4-8,5 × 1,3-3,5 cm, folíolo central elíptico, laterais assimétricos na base, verde-escura, 2 nervuras principais; face adaxial pubérula; face abaxial pubescente; ápice e base obtusos a agudos; margem serrilhada; venação eucamptódroma no folíolo central e 2-nervada em cada folíolo lateral; estípulas lanceoladas. Inflorescências em pseudantos axilares; flores díclinas; 2 dicásios; superior de flores estaminadas; inferior de flores pistiladas; 10 flores estaminadas; dicásio pistilado, séssil, 2 brácteas suborbiculares, ca. 3 flores. Cápsulas 3-lobadas, pubescente, cálice persistente.

Material selecionado: BRASIL. São PaUlo: São Paulo, Parque Estadual das Fontes do Ipiranga, 15-III-2006, B.L.P. Villagra 40 (SP).

\section{FABACEAE}

15.1. Camptosema scarlatinum (Mart.) Burkart, Darwiniana 16: 199. 1970.

Trepadeira herbácea, volúvel. Ramos jovens pubérulos a glabros. Folhas alternas, 3 -folioladas; lâmina 4,5-6 × 1,3-1,5 cm, eglandulosa; linear-lanceolada; ápice agudo; margem inteira; base obtusa a subcordada; face abaxial pubescente; venação eucamptódroma; estípulas não observadas. Inflorescências em racemos axilares; flores 6-10, congestas no ápice da inflorescência; cálice campanulado; corola vermelha. Legumes multisseminados.

Material selecionado: BRASIL. São Paulo: São Paulo, Jardim Botânico de São Paulo, 21-I-1944, M. Kuhlmann s.n. (SP50370).

15.2. Canavalia picta Mart. ex Benth., Comm. Legum. Gen. 71. 1837.

Trepadeira herbácea, volúvel. Ramos jovens pubescentes. Folhas alternas, 3 folioladas; lâmina $6-11 \times 1,8-4 \mathrm{~cm}$, pubérula, eglandulosa; oval ou oblongo-lanceolada; ápice agudo; margem inteira; base obtusa a subcordada; venação eucamptódroma; estípulas não observadas. Inflorescências em racemos multifloros, axilares; flores dispostas na metade superior da inflorescência, monóclinas; cálice tubuloso, 2-labiado, pintalgado de roxo; corola violácea. Legumes multisseminados.

Material selecionado: BRASIL. São Paulo: São Paulo, Parque Estadual das Fontes do Ipiranga, 14-VIII-1968, T. Sendulsky 956 (SP).

15.3. Centrosema grandiflorum Benth., Comm. Leg. Gen. 55. 1837.

Trepadeira herbácea, volúvel. Ramos jovens pubescentes. Folhas alternas, 3 folioladas; lâmina 7,5-10,5 × 4,5-6 cm, eglandulosa; elíptica ou oblonga; face abaxial pubescente; ápice acuminado; margem inteira; base obtusa; venação eucamptódroma; estípulas não observadas. Inflorescências em racemos axilares; flores 3-5, congestas no ápice da inflorescência; flores monóclinas; cálice campanulado, 5-dentado; corola rosada a violácea. Legumes multisseminados.

Material selecionado: BRASIL. São Paulo: São Paulo, Parque Estadual das Fontes do Ipiranga, 6-IV-1934, A. Gehrt s.n. (SP31714). 
15.4. Dalbergia frutescens (Vell.) Britton., Bull. Torrey Bot. Club 16(12): 324. 1889.

Trepadeira lenhosa, escandente. Ramos lenticelados, estriados, glabros. Folhas alternas, pinadas, 5-9 folioladas, folíolos alternos; lâmina 2,2-6,9 × 1,4-3,1 cm, elíptica a oval; cartácea; face adaxial glabra; face abaxial pubescente; ápice agudo; mucronado; margem inteira; base aguda a obtusa; venação eucamptódroma; nervuras secundárias salientes na face adaxial; inconspícuas na face abaxial; estípulas caducas, 1-2 mm compr; pecíolo 1,4-2,5 m compr., glabro a pubérulo. Inflorescências em panículas a corimbos axilares; flores monóclinas; cálice tomentoso; corola creme. Sâmaras fusiformes, núcleo seminífero central, 4,1-6,5 × 1,4-3,1 cm, castanhos.

Material selecionado: BRASIL. São PaUlo: São Paulo, Parque Estadual das Fontes do Ipiranga, 16-XI-1978, M.M.R.F. Melo et al. 114 (SP).

\subsection{Desmodium uncinatum (Jacq.) DC., Prodr. 2:} 331. 1825.

Trepadeira herbácea, volúvel. Ramos estriados, pubescentes. Folhas alternas; 3 folioladas; lâmina $3-8 \times 1,5-3,5 \mathrm{~cm}$, oval, pubescentes; face adaxial esbranquiçada na nervura principal; ápice de agudo a obtuso; margem inteira; base obtusa; venação eucamptódroma; estípulas livres entre si. Inflorescências em racemos laxifloros, axilares e terminais; flores monóclinas, 1,3-1,8 cm compr.; cálice pubérulo a glabrescente; corola alva a violácea. Lomentos 4-8 articulados, pubescentes.

Material selecionado: BRASIL. São PAUlo: São Paulo, Parque Estadual das Fontes do Ipiranga, 10-III-2006, B.L.P. Villagra 68 (SP).

\subsection{Dioclea rufescens Benth., Comm. Legum. Gen.:} 69. 1837.

Trepadeira lenhosa, volúvel. Ramos jovens hirsutos. Folhas alternas, 3 folioladas; lâmina 9-17 × 4,5-9,5 cm, eglandulosa; folíolos ovais ou elípticos; face abaxial pubescente; ápice acuminado; base obtusa; venação eucamptódroma. Inflorescências em racemos multifloros, axilares, 1,3-1,5 cm compr.; flores monóclinas, em fascículos, 3-6, não ressupinadas; cálice campanulado 4-dentado; corola violácea. Folículos multisseminados.

Material selecionado: BRASIL. São Paulo: São Paulo, Parque Estadual das Fontes do Ipiranga, 11-XI-1931, F.C. Hoehne s.n. (SP28442).
15.7. Galactia decumbens (Benth.) Chodat \& Hassl., Bull. Herb. Boissier, ser. 2, 4(9): 900. 1904.

Trepadeira herbácea, volúvel. Ramos jovens pubescentes a glabros. Folhas alternas, 1-foliolada; lâmina 6-9,5 × 3,2-4,1 cm, oval, pubescente; ápice agudo, com apículo; base obtusa a subcordada; venação eucamptódroma, estípulas não observadas. Inflorescências em racemos multifloros, axilares, 1,5-1,8 cm compr.; flores monóclinas, congestas; corola rosada a violácea. Folículos multisseminados.

Material selecionado: BRASIL. São Paulo: São Paulo, Parque Estadual das Fontes do Ipiranga, 25-IV-1934, F.C. Hoehne s.n. (SP32083).

\subsection{Galactia neesii DC., Prodr. 2: 238. 1825.}

Trepadeira herbácea, volúvel. Ramos jovens de hirsutos a glabros. Folhas alternas, 3 folioladas; lâmina 5,5-8 × 2-4,3 cm; oval; ápice agudo, apículado; margem inteira; base cordada; face abaxial densamente tomentosa; venação eucamptódroma; estípulas não observadas. Inflorescências em racemos multifloros, axilares, 1,7-1,9 cm compr.; flores monóclinas, congestas; corola violácea. Folículos multisseminados.

Material selecionado: BRASIL. São PaUlo: São Paulo, Parque Estadual das Fontes do Ipiranga, 3-XII-1933, F.C. Hoehne s.n. (SP31259).

15.9. Machaerium cantarellianum Hoehne, Arq. Bot. Estado São Paulo 1: 30, pl. 29. 1938.

Trepadeira lenhosa, escandente. Ramos jovens pubescentes, pilosidade acinzentada, resina vermelha. Folhas alternas, pinadas, 13-19 folioladas; lâmina 4,5-5,5 × 1,1-1,7 cm, oblongo-lanceolada; face abaxial pubescente; ápice agudo, pequeno apículo; base obtusa a aguda; venação broquidódroma; estípulas espinescentes nos ramos jovens, caducas. Inflorescências em panículas multifloras, axilares; flores monóclinas, 0,8-0,9 cm compr.; cálice seríceo. Sâmaras falciformes, oblongas, 5,8-9,3 cm compr.

Material selecionado: BRASIL. São Paulo: São Paulo, Jardim Botânico, 20-I-1932, F.C. Hoehne s.n. (SP303850).

Ilustração em Sartori \& Tozzi (1998).

15.10. Machaerium lanceolatum (Vell.) J.F. Macbr., Field. Mus. Hist. Nat. ser. Bot. 13: 281. 1943.

Trepadeira lenhosa, escandente. Ramos estriados, glabros. Folhas alternas, pinadas, 7-9 folioladas; 
lâmina 3,5-6,7 × 1,7-2,9 cm, elíptica, alterna ou oposta, cartácea; face adaxial glabra; face abaxial pubescente; ápice acuminado a atenuado; margem inteira; base aguda; venação broquidódroma; estípulas não observadas; pecíolo 2-3,8 cm compr., estriado, glabro. Inflorescências em panículas multifloras; flores monóclinas, 0,6-0,7 cm compr.; cálice seríceo; estandarte esverdeado, seríceo na face externa. Sâmaras falciformes, 4,6-4,7 × 0,9-1 cm, castanhas, núcleo seminífero basal.

Material selecionado: BRASIL. São Paulo: São Paulo, Jardim Botânico de São Paulo, 2-IV-1936, O. Handro \& F.C. Hoehne s.n. (SP 35668).

Ilustração em Sartori \& Tozzi (1998).

\subsection{Machaerium oblongifolium Vogel, Linnaea} 11: 184. 1837.

Trepadeira lenhosa, escandente. Ramos jovens hirsutos, amarelados, resina vermelha. Folhas alternas, pinadas, 7-9 folioladas; lâmina 4-7 × 2,1-3,2 cm, oboval ou oblonga; face abaxial pubescente; ápice de acuminado a emarginado; base de aguda a obtusa; venação broquidódroma; estípulas espinescentes encurvadas, caducas. Inflorescências em racemos paucifloros, axilares; flores monóclinas, 0,7-0,8 cm compr.; cálice seríceo; estandarte arroxeado, seríceo na face externa. Sâmaras oblongas, 4-6,2 cm compr.

Material selecionado: BRASIL. São PAUlo: São Paulo, Parque Estadual das Fontes do Ipiranga, 7-XII-2004, B.L.P. Villagra 60 (SP).

Ilustração em Sartori \& Tozzi (1998).

\subsection{Machaerium triste Vogel, Linnaea 9: 416. 1837.}

Trepadeira lenhosa, escandente. Ramos jovens pubérulos, indumento ferrugíneo. Folhas alternas, pinadas, 5-9 folioladas; lâmina 3-8 × 1,5-3 cm, oval, oblongada, pubérula; ápice rostrado; base obtusa ou aguda; venação broquidódroma; estípulas espinescentes, caducas. Inflorescências em panículas axilares; flores monóclinas, ca. $1 \mathrm{~cm}$ compr.; cálice viloso; estandarte verde-alvacento, seríceo externamente. Sâmaras falciformes, 6,5-7,3 cm compr.

Material selecionado: BRASIL. São Paulo: São Paulo, Parque Estadual das Fontes do Ipiranga, 24-VIII-1951, W. Hoehne s.n. (SP347069).

Ilustração em Sartori \& Tozzi (1998).
15.13. Machaerium uncinatum (Vell.) Benth., Comm. Legum. Gen.: 34. 1937.

Trepadeira lenhosa, escandente. Ramos jovens pubérulos, armados, acúleos unciformes, ao pares, 2-3 mm compr; resina vermelha. Folhas alternas, pinadas, 19-31 folioladas; lâmina 1,3-2 × 0,6-0,9 cm, oboval a oblonga, glabra, cartácea; ápice retuso; margem inteira; base aguda; venação craspedódroma; peciólulo 7-11 mm compr.; estriado, glabro; estípulas espinescentes, 1,5-2 mm compr. Inflorescências em panículas axilares; flores monóclinas, cálice seríceo a glabro; corola creme, $0,7-0,8 \mathrm{~cm}$ compr., estandarte vináceo. Sâmaras falciformes, 2,9-3 × 0,9-1 cm, castanhas, núcleo seminífero basal. Sementes sem arilo.

Material selecionado: BRASIL. São PAUlo: São Paulo, Parque Estadual das Fontes do Ipiranga, 2-X-1933, F.C. Hoehne s.n. (SP303851).

Ilustração em Sartori \& Tozzi (1998).

15.14. Macroptilium erythroloma (Mart. ex Benth.) Urb., Symb. Antill. 9(4): 457. 1928.

Trepadeira herbácea, volúvel. Ramos jovens hirsutos. Folhas alternas, 3 folioladas, lobadas; lâmina 6-8 × 3-3,5 cm, oval, pubescente, eglandulosa; ápice obtuso, apículo ausente; margem inteira, base obtusa; venação eucamptódroma; estípulas não observadas. Inflorescências em racemos multifloros; axilares; flores monóclinas, dispostas na metade superior do racemo, 1,1-1,4 cm compr., não ressupinadas; cálice campanulado, 5-dentado; corola vermelha, estandarte dorsal sem calcar, estiletes curvos. Legumes multisseminados.

Material selecionado: BRASIL. São Paulo: São Paulo, Parque Estadual das Fontes do Ipiranga, 15-III-1934, F.C. Hoehne s.n. (SP31676).

15.15. Mimosa bimucronata (DC.) O. Kuntze., Revis. Gen. P1. 198. 1891.

Trepadeira lenhosa, escandente, armada, espinhos retos. Ramos pubescentes. Folhas alternas, bipinadas, 6-10-jugas, 14-30 foliólulos; lâmina 9-14 × 6-9 cm, glabra, venação actinódroma reticulada. Inflorescências em panículas de glomérulos, terminais; 15-40 cm compr.; flores monóclinas, 4-meras, brancas, perfumadas; cálice denteado, inconspícuo, campanulado, 0,8-1 mm compr.; corola 2,5-4 mm compr. Craspédios inermes, não verrucoso. Sementes sem arilo. 
Material selecionado: BRASIL. São Paulo: São Paulo, Parque Estadual das Fontes do Ipiranga, 15-III-1944, W. Hoehne s.n. (SP185887).

\subsection{Phanera angulosa (Vogel) Vaz, Rodriguésia 61(Sup.): S36. 2010.}

\section{Figura 28}

Trepadeira lenhosa, escandente e preensil; gavinha 2, alterna à folha. Ramos sulcados inermes, pubescente. Folhas alternas, inteiras a 2-folioladas; lâmina 4,5-13 × 6-8 cm compr., eglandulosa; venação actinódroma basal; pecíolo 3,5-5,5 cm compr.; estípulas caducas. Inflorescências em racemos terminais; multifloros; flores monóclinas; cálice campanulado; corola zigomorfa; pétalas esbranquiçadas. Legumes comprimidos lateralmente.

Material selecionado: BRASIL. São Paulo: São Paulo, Jardim Botânico de São Paulo, 25-XI-1934, F.C. Hoehne s.n. (SP28347, holótipo), Parque Estadual das Fontes do Ipiranga, 8-V-2007, B.L.P. Villagra 247 (SP).

15.17. Rhynchosia phaseoloides (Sw.) DC., Prodr. 2: 385.1825.

Trepadeira herbácea, volúvel. Ramos jovens hirsutos. Folhas alternas, pinadas, 3-folioladas; lâmina 6-8 $\times 3-3,5 \mathrm{~cm}$, oval, eglandulosa, pubescente; ápice obtuso, apículo ausente; margem inteira; base obtusa; venação actinódroma basal; estípulas não observadas. Inflorescências em racemos multifloros, axilares; flores monóclinas, dispostas na metade superior do racemo, 1,1-1,4 cm compr., não ressupinadas; cálice campanulado, 5-dentado; corola vermelha, estandarte sem calcar dorsal; estilete sigmóide. Legumes multisseminados.

Material selecionado: BRASIL. São Paulo: São Paulo, Parque Estadual das Fontes do Ipiranga, 7-I-1977, M.G.L. Wanderley s.n. (SP150998), Parque Estadual das Fontes do Ipiranga, 25-V-2007, B.L.P. Villagra 208 (SP).

\subsection{Senegalia grandistipula (Benth.) Seigler \&} Ebinger, Phytologia 88(1): 53. 2006.

Trepadeira lenhosa, escandente, armada, espinhos recurvos. Ramos cilíndricos. Folhas alternas, bipinadas, 6-20-jugas; pina 10-25 foliólulos; lâmina 20-26 × 10-17 cm, oval, glabra, persistente; venação actinódroma reticulada; pecíolo e ráquis glabros; estípulas foliáceas. Inflorescências em panículas de racemos, fasciculadas terminais, eixo 1,5-2 cm compr.; flores curto-pediceladas. Legumes estipitados.

Material selecionado: BRASIL. São Paulo: São Paulo, Jardim Botânico de São Paulo, 14-VII-1941, O. Handro s.n. (SP31952).

15.19. Senegalia martii (Benth.) Seigler \& Ebinger, Phytologia 88(1): 57. 2006.

Figura 29

Trepadeira lenhosa, escandente, armada, espinhos recurvos. Ramos angulosos, estriados e pubérulos. Folhas alternas, bipinadas, 15-20-jugas, pina 40-60 foliólulos; lâmina $14-18 \times 8-11 \mathrm{~cm}$, pubescente, caduca, venação actinódroma reticulada; pecíolo e ráquis pubescentes; estípulas lineares. Inflorescências em panículas de glomérulos terminais, eixo 0,5-1 cm compr.; flores monóclinas; sésseis. Legumes estipitados.

Material selecionado: BRASIL. São PAUlo: São Paulo, Parque Estadual das Fontes do Ipiranga, 22-II-2005, B.L.P. Villagra 22 (SP).

15.20. Vigna candida (Vell.) Maréchal, Mascherpa \& Stainier, Táxon 27: 201. 1978.

Trepadeira herbácea, volúvel. Ramos jovens, glabrescentes a glabros. Folhas alternas, 3-folioladas; lâmina 9-10,5 × 5,5-7,2 cm, rombóide, glabrescente a glabra; ápice acuminado apículado; margem inteira; base obtusa; venação eucamptódroma; estípulas ausentes ou caducas. Inflorescências em racemos axilares; flores monóclinas, 1-2, 3,5-4 cm compr.; corola violácea; estilete sigmóide. Legumes 4-5 cm compr.

Material selecionado: BRASIL. São PaUlo: São Paulo, Parque Estadual das Fontes do Ipiranga, 10-VIII-1967, R. Faria 41 (SP).

15.21. Vigna luteola (Jacq.) Benth., Fl. bras. 15(1): 194. 1859.

Trepadeira herbácea, volúvel. Ramos jovens hirsutos a glabros. Folhas alternas, 3-folioladas; lâmina 3,8-6,5 × 2-3,7 cm, oval, pubérula; ápice obtuso apículado; margem inteira; base obtusa; venação eucamptódroma; estípulas ausentes ou caducas. Inflorescências em racemos axilares; flores monóclinas, 5-9, 1,1-1,6 cm compr.; corola amarela; estilete curvo. Legumes 4-4,5 cm compr. 
Material selecionado: BRASIL. São Paulo: São Paulo, Jardim Botânico de São Paulo, 4-V-1937, F.C. Hoehne s.n. (SP38326).

\section{LOGANIACEAE}

\subsection{Strychnos brasiliensis (Spreng.) Mart., Flora 24} (Beibl. 2): 84. 1841.

Trepadeira lenhosa, escandente. Ramos jovens velutinos, lenticelados; armados, espinhos retos. Folhas simples, opostas; lâmina 1,8-3,7 ×1,1-1,9 cm, elíptica, oboval ou cuneiforme, glabra, membranácea; ápice mucronado, obtuso ou emarginado; base aguda ou cuneada; 5-nervada, venação acródoma suprabasal, velutinas. Inflorescências em cimeiras laxas, 1,4-2,3 cm compr.; brácteas e bractéolas lanceoladas; cálice $1 \mathrm{~mm}$ compr., lobos triangulares, velutino; corola pubérula, tricomas alvos na fauce. Bagas esféricas.

Material selecionado: BRASIL. São PaUlo: São Paulo, Parque Estadual das Fontes do Ipiranga, 1-XII-1976, L.B. Noffs et al. 9 (SP).

16.2. Strychnos nigricans Progel in Mart., Fl. bras. 6(1): 280. 1868.

Trepadeira lenhosa, preensil; gavinha 2-ramificada, ápice espessado. Ramos pubescentes; armados, espinhos recurvados. Folhas simples, opostas, lâmina 1,4-4 × 1-1,8 cm, elíptica, lanceolada ou oblonga, membranácea, glabra; ápice acuminado; base aguda ou obtusa; 3-nervada, venação acródroma suprabasal, axilas das nervuras pubescentes. Inflorescências em cimeiras, terminais, densifloras, 1,6-3,5 cm compr.; brácteas e bractéolas lanceoladas; cálice pubérulo, lobos triangulares; corola pubérula externamente. Bagas subesféricas, alaranjadas, 2,5-3 cm diâm.

Material selecionado: BRASIL. São Paulo: São Paulo, Parque Estadual das Fontes do Ipiranga, 9-VII-1980, S.A. Chiea 123 (SP).

\section{MALPIGHIACEAE}

17.1. Banisteriopsis adenopoda (A. Juss.) B. Gates, F1. Neotrop. 30: 110. 1982.

Figura 30

Trepadeira lenhosa, volúvel. Ramos cilíndricos, pubérulos. Folhas simples, opostas; lâmina 6,5-12,5 $\times 3,5-7 \mathrm{~cm}$, oval a oval-arredondada; face adaxial glabrescente; face abaxial velutina; 2-6 glândulas cupuliformes nas nervuras secundárias, simétricas; ápice obtuso a apiculado; margem plana; base obtusa a arredondada; venação eucamptódroma; estípulas ausentes. Inflorescências em panículas de umbelas, axilares ou terminais; corola amarela, glabra; estigma apical capitado. Samarídeos pubérulos, ca. $3 \mathrm{~cm}$ compr., alas laterais inteiras.

Material selecionado: BRASIL. São Paulo: São Paulo, Parque Estadual das Fontes do Ipiranga, 25-V-2007, B.L.P. Villagra 217 (SP).

17.2. Banisteriopsis campestris (A. Juss.) Little, Phytologia 6: 506. 1959.

Trepadeira lenhosa, volúvel. Ramos cilíndricos, pubérulos. Folhas simples, opostas; lâmina 7,5-8,5 × 5,5-7 cm, oval-arredondada; face adaxial hirsuta; face abaxial castanho-velutina; ápice obtuso a arredondado, mucronado; margem pouco revoluta, base obtusa a arredondada; 2 glândulas cupuliformes, na base do limbo próximas à nervura principal; venação eucamptódroma; estípulas ausentes. Inflorescências em panículas de umbelas, axilares ou terminais; corola rósea, glabra. Samarídeos ca. 2,5 cm compr.

Material selecionado: BRASIL. São Paulo: São Paulo, Parque Estadual das Fontes do Ipiranga, 31-XII-1911, A.C. Brade 5312 (SP).

\subsection{Heteropterys chrysophylla (Lam.) Kunth, Nov.} gen. sp. 5: 126. 1821.

Trepadeira lenhosa, volúvel. Ramos lisos, glabros. Folhas simples, opostas; lâmina 11,5-23 × 4,5-9 cm, oblongo-oval; face adaxial glabra; face abaxial castanho-serícea; glândulas cupuliformes nas nervuras secundárias; ápice truncado a emarginado; margem plana; base obtusa; truncada; venação eucamptódroma; pecíolo 2-2,5 cm compr. Inflorescências em panículas de umbelas amplas; cálice 8-glanduloso; pétalas amarelas.

Material selecionado: BRASIL. São Paulo: São Paulo, Parque Estadual das Fontes do Ipiranga, 26-V-1978, H. Makino 132 (SP).

17.4. Heteropterys intermedia (A. Juss.) Griseb. in Mart., Fl. bras. 12(1): 62. 1858.

Figura 31

Trepadeira lenhosa, volúvel. Ramos lisos, glabros. Folhas simples, opostas; lâmina 7,5-11,5 × 2-4 cm, oval 

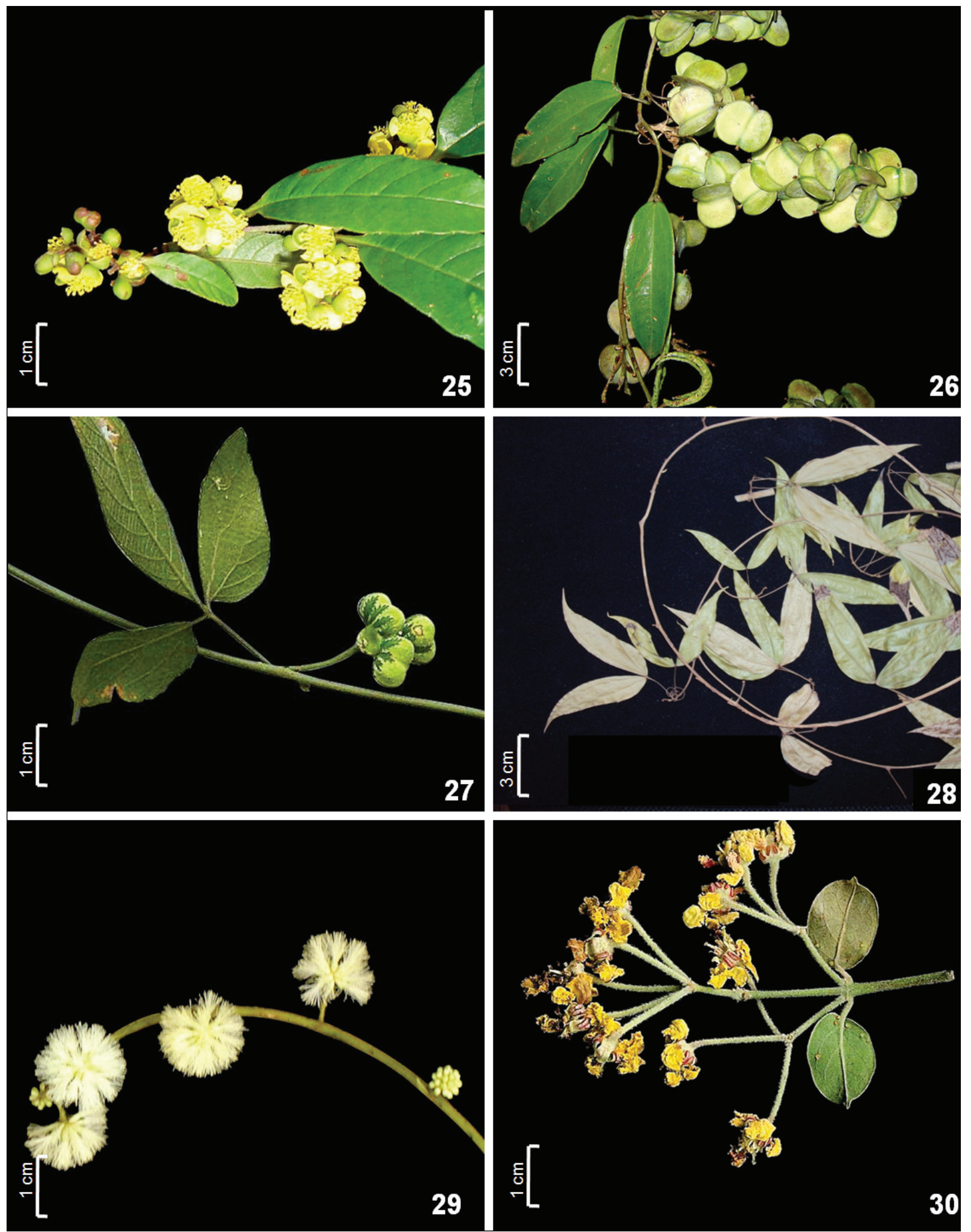

Figura 25-30. Dilleniaceae. 25. Davilla rugosa. Dioscoreaceae. 26. Dioscorea olfersiana. Euphorbiaceae. 27. Dalechampia triphylla. Fabaceae. 28. Phanera angulosa. 29. Senegalia martii. Malpiguiaceae. 30. Banisteriopsis adenopoda.

Figure 25-30. Dilleniaceae. 25. Davilla rugosa. Dioscoreaceae. 26. Dioscorea olfersiana. Euphorbiaceae. 27. Dalechampia triphylla. Fabaceae. 28. Phanera angulosa. 29. Senegalia martii. Malpiguiaceae. 30. Banisteriopsis adenopoda. 
a elíptica, cartácea, glabra; ápice agudo a acuminado; margem inteira; base obtusa; pontuações glandulares negras próximas às margens; venação eucamptódroma; pecíolo 0,9-2 cm compr., canaliculado na face adaxial, glabro, 1 par de glândulas localizadas no ápice ou eglanduloso. Inflorescências em panículas de tirsos, axilares ou terminais; corola amarela, 3-5 $\mathrm{mm}$ compr. Samarídeos 2,1-2,5 $\times 0,8-1 \mathrm{~cm}$, ala dorsal rósea quando madura, margem inferior espessada.

Material selecionado: BRASIL. São Paulo: São Paulo, Parque Estadual das Fontes do Ipiranga, 27-III-2007, B.L.P. Villagra 196 (SP); 18-XII-2006, B.L.P. Villagra 154 (SP).

Ilustração em Mamede (1992).

17.5. Hiraea fagifolia (DC.) A. Juss., Ann. Sci. Nat. 13: 258. 1840.

Trepadeira lenhosa, volúvel. Ramos estriados, pubérulos. Folhas simples, opostas; lâmina 7,5-11 × 3,5-5,5 cm, oboval; face adaxial glabra; face abaxial pubescente apenas na nervura principal, glândulas cupuliformes; ápice obtuso, apiculado; margem plana; base aguda; venação broquidódroma; estípulas adnatas ao pecíolo. Inflorescências em umbelas axilares; cálice 8-glanduloso; pétalas amarelas, membranáceas. Samarídeos, alas laterais inteiras.

Material selecionado: BRASIL. SÃo PAUlo: São Paulo: Parque Estadual das Fontes do Ipiranga, 5-I-1932, F.C. Hoehne s.n. (SP28668).

Ilustração em Mamede (1992).

17.6. Mascagnia sepium (A. Juss.) Griseb., Fl. bras. 12(1): 96. 1858.

Trepadeira lenhosa, volúvel. Ramos estriados, púberulos quando jovens. Folhas simples, opostas; lâmina 4,5-6 × 2,5-3 cm, oval-elíptica, glabra, eglandulosas; ápice apiculado; margem plana; base obtusa; venação broquidódroma; estípulas livres do pecíolo. Inflorescências em racemos axilares; pedicelos articulados. Samarídeos glabros, ala lateral única.

Material selecionado: BRASIL. São PaUlo: São Paulo, Parque Estadual das Fontes do Ipiranga, 27-XII-1945, M. Kuhlmann 3292 (SP).

17.7. Tetrapterys mucronata Cav., Diss. 9: 434, tab. 262. 1790.

Figura 32

Trepadeira lenhosa, volúvel. Ramos estriados, glabros. Folhas simples, opostas; lâmina 7-12,5 × 1,5-4,5 cm, elíptico-lanceolada, glabra; glândulas cupuliformes na base do limbo próximo à nervura principal; ápice obtuso-acuminado; margem pouco revoluta; base aguda; venação broquidódroma; pecíolo eglanduloso; estípulas intrapeciolares, persistentes. Inflorescência em panículas; corola amarela-alaranjada, 5-7 mm compr. Samarídeos com alas laterais divididas em forma de $\mathrm{x}$, avermelhadas.

Material selecionado: BRASIL. São Paulo: São Paulo, Parque Estadual das Fontes do Ipiranga, 21-VIII-2006, B.L.P. Villagra 126 (SP).

\subsection{Tetrapterys phlomoides (Spreng.) Nied.,} Pfanzenreich 141: 208. 1928.

Trepadeira lenhosa, volúvel. Ramos jovens tomentosos, pubescentes a glabros quando adultos. Folhas simples, opostas; lâmina 5,2-6,9 × 2,3-4,4 cm, elíptica a oboval, cartácea, eglandulosa; ápice obtuso a arredondado, mucronado; margem inteira; base aguda; face adaxial glabra; face abaxial pubescente; tricomas malpighiáceos; venação eucamptódroma; pecíolo pubescente; 1-2 pares de glândulas no ápice. Inflorescências em panículas; corola amarela a alaranjada, 5-7 mm compr. Samarídeos com alas laterais divididas em forma de $\mathrm{x}$, avermelhadas, as superiores maiores 1,6-2,1 $\times 0,5-0,6 \mathrm{~cm}$, as inferiores menores $0,8-1,1 \times 0,3-0,5 \mathrm{~cm}$.

Material selecionado: BRASIL. São PAULo: São Paulo, Parque Estadual das Fontes do Ipiranga, 28-XI-1980, N.A. Rosa \& J.M. Pires 3987 (SP).

\section{MARCGRAVIACEAE}

18.1. Marcgravia polyantha Delpino, Atti Soc. Ital. Sci. Nat. 12: 182, 210. 1869.

Trepadeira lenhosa, radicante. Ramos com lenticelas, glabros, dimorfos, estéreis presos ao substrato pelas raízes, férteis livres, pêndulos. Folhas simples, alternas; lâmina 3,3-6,5 × 1-2,3 cm, lanceolada a elíptica, glabra, coriácea; ápice agudo a acuminado; margem inteira; base aguda; numerosos nectários dispostos entre a nervura principal e a margem da face abaxial; venação camptódroma; sésseis; dísticas. Inflorescências em umbelas; 4-5 profilos nectaríferos verdes. Cápsulas loculicidas, multisseminadas.

Material selecionado: BRASIL. São PAULO: São Paulo, Parque Estadual das Fontes do Ipiranga, 4-VII-1932, F.C. Hoehne s.n. (SP29759).

Ilustração em Reis (2002). 
18.2. Schwartzia brasiliensis (Choisy) Bedell ex Giraldo-Cañas, Caldasia 23(1): 341. 2001.

Trepadeira lenhosa, escandente. Ramos estriados, glabros, não descamantes, castanhos, inermes. Folhas simples, alternas, espiraladas; lâmina 8,6-12 × 2,8-5 cm, oboval a espatulada, coriácea, glabra; ápice arredondado, retuso a emarginado; margem inteira; base atenuada; numerosos nectários dispostos entre a nervura principal e a margem da face abaxial; venação eucamptódroma; pecíolo 0,9-1,3 cm compr., canaliculado na face adaxial, glabro. Inflorescências em racemos; corola vermelha, 5-8 mm compr.; 30-91 profilos nectaríferos vináceos no pedicelo. Cápsulas globosas, 8-12 mm diâm.

Material selecionado: BRASIL. SÃo Paulo: São Paulo, Parque Estadual das Fontes do Ipiranga, 10-II-1935, O. Handro s.n. (SP32835).

Ilustração em Reis (2002).

\section{MENISPERMACEAE}

19.1. Abuta selloana Eichler, Flora 47: 389. 1864. Figura 33

Trepadeira lenhosa, volúvel. Ramos glabros, lenticelados. Folhas simples, alter nas; lâmina 6-12 × 3-5 cm, oval a oblonga, glabra, coriácea, lustrosa; ápice cuspidado a retuso; base aguda a obtusa; venação actinódroma basal, 3-nervada; pecíolo 3-8 cm compr., dilatado nas extremidades. Inflorescências estaminadas em panículas; flores monoclamídeas; sépalas externas 3, internas 3, maiores. Drupas oblongas, 1,5-1,8 cm compr., epicarpos verdes, amarelos quando maduros, pretos quando secos.

Material selecionado: BRASIL. São Paulo: São Paulo, Parque Estadual das Fontes do Ipiranga, 6-III-2007, B.L.P. Villagra 179 (SP).

Ilustração em Costa \& Sano (2007).

\subsection{Cissampelos andromorpha DC., Syst. Nat.} 1: 539.1818.

Trepadeira herbácea, volúvel. Ramos estriados, glabros. Folhas simples, alternas; lâmina 4-6 × 3-5 cm, cordiforme, pubescente, cartácea; ausentes em ramos mais velhos; ápice apiculado; base obtusa ou cordada; venação actinódroma basal, 5-7 nervada; pseudoestípulas ausentes. Inflorescências estaminadas, cimoso-paniculadas, axilares ou caulifloras, 4-13,5 cm compr.; brácteas diminutas. Inflorescências pistiladas em fascículos, pseudo-racemosas, axilares ou caulifloras, 9-13 cm compr.; brácteas diminutas; flores diclamídeas, creme-esverdeadas; flor estaminada 4-mera, dialissépala, gamopétala; flor pistilada reduzida, sépala 1 , pétala 1 , carpelo 1 . Drupas obovais, 1-1,2 cm compr.

Material selecionado: BRASIL. São Paulo: São Paulo, Parque Estadual das Fontes do Ipiranga, 26-X-1978, M. Kirizawa 249 (SP).

Observações: espécie observada na década de 1980 em população abundante (Strufaldi-De-Vuono 1985), no período 2006-2007 não foi coletada fértil.

19.3. Disciphania modesta Diels, Notizbl. Bot. Gart Berlin-Dahlem 13: 28. 1936.

\section{Figura 34}

Trepadeira herbácea, volúvel. Ramos estriados, lisos, glabros. Folhas simples, alternas; lâmina 4-9 × 3-8,5 cm, cordiforme, glabra, cartácea; ápice caudado; base cordada; venação actinódroma basal, 5-7 nervada; pseudoestípulas ausentes. Inflorescências estaminadas em espigas axilares, 2,5-10 cm compr.; flores diclamídeas, esverdeadas, bracteoladas, sésseis; flor estaminada, sépalas 6 , unidas até metade do comprimento formando um tubo campanulado; pétalas 6; flor pistilada, perianto semelhante, carpelos 3 . Drupas oblongo-elipsóides, ca. 1,8 cm compr., verdes, vermelhos quando maduros, mesocarpo mucilaginoso.

Material selecionado: BRASIL. São PAUlo: São Paulo, Parque Estadual das Fontes do Ipiranga, 24-I-2007, B.L.P. Villagra \& A. C. Laurenti 175 (SP).

Ilustração em Costa \& Sano (2007).

19.4. Hyperbaena domingensis (DC.) Benth., J. Proc. Linn. Soc., Bot. 5, Suppl. 2: 50. 1861.

Trepadeira lenhosa, volúvel. Ramos pubescentes. Folhas simples, alternas; lâmina 5,5-8 × 3-4,5 cm, oboval a oblonga, glabra a esparsamente pubescente principalmente na nervura central na face abaxial, coriáceas; ápice cuspidado a retuso; base subcuneada; venação actinódroma basal, geralmente 3-nervada; pseudoestípulas ausentes. Inflorescências estaminadas em panículas axilares, 13-19 cm compr.; brácteas 
diminutas; flores diclamídeas, esverdeadas, bracteoladas; flor estaminada, 2 verticilos, sépalas 6 , pétalas 6. Drupas obovais, 1,5-2 cm compr.

Material selecionado: BRASIL. São Paulo: São Paulo, Parque Estadual das Fontes do Ipiranga, 13-XI-1931, F.C. Hoehne s.n. (SP28450).

Ilustração em Costa \& Sano (2007).

19.5. Odontocarya acuparata Miers, Contr. Bot. 3: 61, t. 100. 1864.

Figura 35

Trepadeira herbácea, volúvel. Ramos estriados, glabros. Folhas simples, alternas; lâmina 4-9 ×4-8,5 cm, cordiforme, glabra, cartácea; ápice acuminado a apiculado; base cordada; venação actinódroma basal, 5-nervada; pseudoestípulas ausentes. Inflorescências estaminadas em racemos axilares, 5-14,5 cm compr. Inflorescências pistiladas, 8,5-14 cm compr.; flores diclamídeas, esverdeadas, bracteoladas, pediceladas; flor estaminada, 2 verticilos, sépalas 6 , pétalas 6 ; flor pistilada estaminódios 6 , lineares, carpelos 3. Drupas obovais, 1,2-1,4 cm compr.

Material selecionado: BRASIL. São PaUlo: São Paulo, Parque Estadual das Fontes do Ipiranga, 27-X-2005, B.L.P. Villagra 47 (SP).

Ilustração em Costa \& Sano (2007).

\section{PASSIFLORACEAE}

\subsection{Passiflora alata Curtis, Bot. Mag. 2: pl.} 66. 1788.

Trepadeira herbácea, preensil, gavinha axilar simples. Ramos 4-angular. Folhas simples, alternas, inteiras; lâmina 6,5-13 × 4-9,7 cm, ovada, membranácea; ápice agudo-rostrado; margem inteira a raramente denticulada; base arredondada a obtusa; venação eucamptódroma; pecíolo 1,8-4,2 cm compr., 1-2 pares de nectários crateriformes; estípula falcada. Flores solitárias, vistosas, odoríferas, 6-11 cm diâm., brácteas verticiladas, verdes; sépalas carnosas, pétalas oblongas, corona de 3-5 séries, filiformes. Bagas elípticas, amarelas, 8-10 cm compr.

Material selecionado: BRASIL. São PAUlo: São Paulo, Parque Estadual das Fontes do Ipiranga, 13-VIII-1968, T. Sendulsky 1003 (SP).
20.2. Passiflora cincinnata Mast., Gard. Chron. 1868: 966. 1868.

Trepadeira herbácea, preensil, gavinha axilar simples. Ramos velhos, glabros, quilhas suberosas. Folhas simples, alternas, 3-lobadas; lâmina 4,9-10,5 × 5,3-14,5 cm, membranácea; lobos oval-oblongos a oboval-oblongos; margem serreada a crenada, glandular; base obtusa; 1 par de nectários crateriformes; venação actinódroma; estípula linear, glandular; ocelos ausentes. Flores solitárias, vistosas, 5,5-10 cm diâm.; brácteas verticiladas, membranáceas, frequentemente glandulares na base, verde-pálidas; hipanto campanulado; sépala cartácea, azul-arroxeada; pétala oblongo-lanceolada, corona em várias séries. Bagas arredondadas a ovóides.

Material selecionado: BRASIL. SÃo PaUlo: São Paulo, Parque Estadual das Fontes do Ipiranga, 1973, equipe de botânica s.n. (IAC24934).

\subsection{Passiflora edulis Sims in Curtis, Bot. Mag. 45:} tab. 1989. 1818.

Trepadeira lenhosa, preensil, gavinha axilar simples. Ramos estriados, glabros. Folhas simples, alternas, profundamente 3-lobadas; lobo central $6-6,8 \times 3,2-4,4 \mathrm{~cm}$; lobos laterais 4,7-5,6 $\times 2,4-3,4 \mathrm{~cm}$, elípticos, membranáceos, glabros; ápice agudo a acuminado; margem glanduloso-serreada; base obtusa; aguda a cordada; venação actinódroma, 3-nervada; pecíolo 2,9-3,4 cm compr., estriado, glabro, 1 par de nectários no ápice próximo à base do limbo, sésseis ou curtamente estipitados. Flores solitárias, axilares, ca. $4 \mathrm{~cm}$ compr., pedicelo ca. 1,5 cm compr.; sépalas carnosas; pétalas alvas, corona em 5-7 séries. Bagas globosas ou ovóides, 4,8-6,6 cm diâm.

Material selecionado: BRASIL. São PAUlo: São Paulo, Parque Estadual das Fontes do Ipiranga, 20-IX-1934, F.C. Hoehne s.n. (SP32053).

20.4. Passiflora haematostigma Mart. ex Mast. in Mart., Fl. bras. 13(1): 574. tb. 108, fig. 1. 1872.

Trepadeira herbácea, preensil, gavinha axilar simples. Ramos cilíndricos, curtamente velutinos. Folhas simples, alternas, inteiras; lâmina 6-8 × 2,5-3,5 cm, elíptica, oblongo-ovada a lanceolada-ovada, cartácea a coriácea; ápice agudo-mucronulado; margem levemente revoluta; base aguda a cordada; face adaxial glabra; face abaxial velutina com a nervura central proeminente e 
esparsamente pubescente; venação eucamptódroma; pecíolo curtamente velutino, 1-3 cm compr.; 1 par de nectários sésseis, elípticos, pretos, conspícuos, próximos do ápice; estípula falcada. Flores 1-2 por nó, 3-4 cm diâm., pedicelo 1,5-3 cm compr.; brácteas dispersas na metade inferior do pedicelo, setáceas; sépalas linear-oblongas, externamente pubescentes e esverdeadas, internamente glabras e alvas; pétalas alvas, corona em 2 séries. Bagas fusiformes.

Material selecionado: BRASIL. São PAULo: São Paulo, Parque Estadual das Fontes do Ipiranga, 1-XII-1933, O. Handro s.n. (SP625).

\subsection{Passiflora jilekii Wawra, Österr. bot. Z.} 13: 110. 1863.

Trepadeira herbácea, preensil, gavinha axilar simples. Ramos estriados, glabros. Folhas simples, alternas, inteiras; lâmina 6-11 × 3,2-8 cm, oval-lanceolada, coriácea; ápice agudo; margem inteira; base cordada; face adaxial glabra; face abaxial pubérula; venação eucamptódroma; pecíolo 1,6-2,2 cm compr., estriado ou canaliculado na face adaxial; nectários 2-5, estipitados; estípulas foliáceas, 1,1-1,6 cm compr., reniformes. Flores 2, 3,6-5,4 cm diâm.; pedicelo 1,4-3,4 cm compr.; brácteas verticiladas, obovado-lanceoladas a ovais; sépalas subcoriáceas, ovado-lanceolada; corona 2-3 séries. Bagas globosas ou ovóides, 1,8-3 cm diâm.

Material selecionado: BRASIL. São Paulo: São Paulo, Parque Estadual das Fontes do Ipiranga, 3-V-1988, F. Barros \& R.T. Ninomya 1513 (SP).

20.6. Passiflora miersii Mart. in Mart., Fl. bras. 13(1): 561. 1872.

Figura 36

Trepadeira herbácea, preensil, gavinha axilar simples. Ramos cilíndricos, lisos, glabros. Folhas simples, alternas, inteiras; lâmina 3-5 × 1,5-3,5 cm, oval, membranácea a subcoriácea; ápice arredondado a agudo; aristado; margem glandular, crenulada a serreada; base truncada a cordada; venação actinódroma, 3(-5)-nervada; pecíolo estipitado, 1 par de nectários no terço superior; estípula reniforme ca. 1,5 cm compr. Flores solitárias; brácteas dispersas, elíptico-lanceoladas a setáceas; sépalas oblongas a lanceoladas, esverdeadas; pétalas alvas; corona 4 séries filiformes, bandeadas de alva e vinácea. Bagas obovóides, ca. 3,5 cm compr.
Material selecionado: BRASIL. São Paulo: São Paulo, Parque Estadual das Fontes do Ipiranga, 12-XII-2006, B.L.P. Villagra 147 (SP).

20.7. Passiflora misera Kunth in Humb., Bonpl. \& Kunth., Nov. gen. sp. 2: 136. 1817.

Trepadeira herbácea, preensil, gavinha axilar simples. Ramos 5-angular, pubescentes. Folhas simples, alternas, 2-3 lobadas; lâmina 5-8 $\times 1-3,5 \mathrm{~cm}$, obtusa a cordada, membranácea; margem revoluta; ocelos entre as nervuras principais dos lobos laterais, principalmente 2, na base; venação actinódroma; pecíolo 0,6-2,1 cm compr.; nectários ausentes. Flores 1(-2), 3,1-3,5 cm diâm.; brácteas dispersas; setáceas; sépalas oblongo-ovadas, membranáceas, verdes; pétalas alvas; corona em 2 séries, alvas. Bagas elípticoarredondadas, roxo-enegrecidas 1,1-1,5 cm compr.

Material selecionado: BRASIL. São Paulo: São Paulo, Parque Estadual das Fontes do Ipiranga, 22-III-1935, s/ coletor (SP32575).

20.8. Passiflora morifolia Mast. in Mart., Fl. bras. 13(1): 555. 1872.

Trepadeira herbácea, preensil, gavinha axilar simples. Ramos sulcados, híspidos. Folhas simples, alternas, 3-lobadas; lâmina 4-9 × 5,5-9,5 cm, membranácea; ápice agudo; margem denteada; base cordada; ocelos ausentes; venação actinódroma basal; pecíolo 1,9-7,3 cm compr.; 1 par de nectários próximo ao ápice; estípula ovada. Flores (1-)2 por nó; 2,3-3,2 cm diâm.; brácteas dispersas, setáceas; sépalas membranáceas, oblongo-lanceoladas, alvas; pétalas alvas; corona em 1 série, base vinácea. Bagas muricado-globosas, arroxeadas, 2,3-3 mm diâm.

Material selecionado: BRASIL. São PaUlo: São Paulo, 21-III-1945, W. Hoehne s.n. (SPF11470).

\subsection{Passiflora organensis Gardner in Hook., Lond.}

\section{J. Bot. 4: 104. 1845.}

Trepadeira herbácea, preensil, gavinha axilar simples. Ramos subangulares, estriados, glabros. Folhas simples, alternas, 2-lobadas, incipiente 3-lobadas; lobo central 0,3-0,5 × 1,8-2,5 cm; lobos laterais 3,8-4,5 $\times$ 2,7-3,5 cm, ovais, membranáceos, glabros, ocelados; ápice obtuso a agudo, mucronulado; margem inteira; base arredondada; venação actinódroma basal; 3-nervada; pecíolos 2,8-3,1 cm compr., estriados, glabros; nectários ausentes. Flores solitárias axilares, 

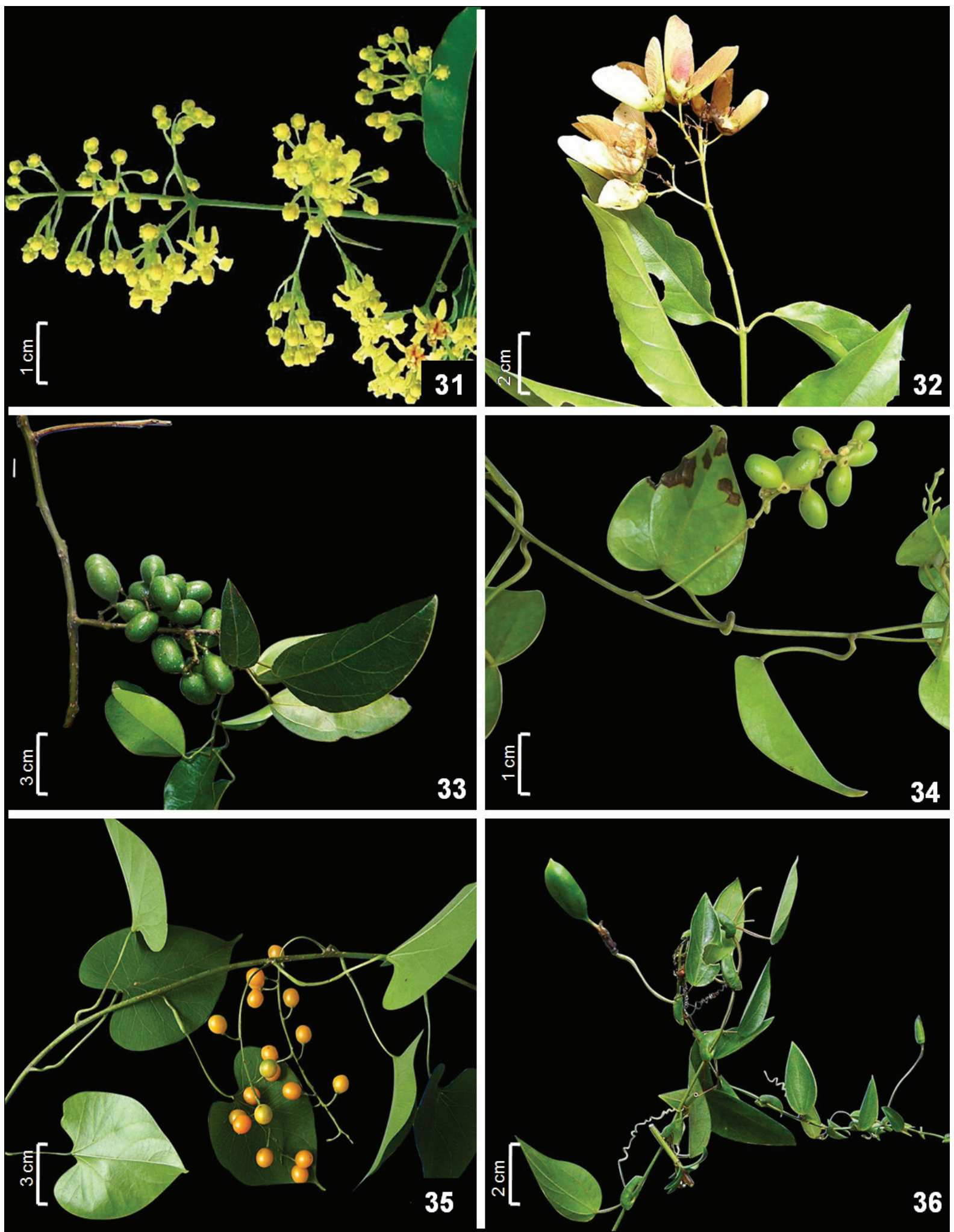

Figura 31-36. Malpighiaceae. 31. Heteropterys intermedia. 32. Tetrapterys mucronata. Menispermaceae. 33. Abuta selloana. 34. Disciphania modesta. 35. Odontocarya acuparata. Passifloraceae. 36. Passiflora miersii.

Figure 31-36. Malpighiaceae. 31. Heteropterys intermedia. 32. Tetrapterys mucronata. Menispermaceae. 33. Abuta selloana. 34. Disciphania modesta. 35. Odontocarya acuparata. Passifloraceae 36. Passiflora miersii. 
ca. 2,4 cm diâm., amarelo-esverdeadas; pedicelo 1,8-5 cm compr., articulado; brácteas alternas; sépalas oblongo-lanceoladas, alvas a verdes; pétala alvas a verdes; corona em 1 série. Bagas globosas, 1,5-2 cm diâm.

Material selecionado: BRASIL. São PAULo: São Paulo, Parque Estadual das Fontes do Ipiranga, 20-I-1976, M. Sakane 412 (SP).

20.10. Passiflora sidaefolia M. Roemer, Fam. nat. syn. monogr. 2: 173. 1846.

Trepadeira herbácea, preensil, gavinha axilar simples. Ramos cilíndricos, glabros. Folhas simples, alternas, 3-lobadas; lâmina 4,7-8 × 3,5-5,5 cm; lobos arredondados, subcoriáceos; face adaxial lustrosa; ocelos ausentes; margem inteira, base arredondada; venação actinódroma; pecíolo 1,2-2,3 cm compr., 1(-2) pares de nectários estipitados no terço superior ou próximos ao meio, aplanados; estípulas subcoriáceas, reniformes. Flores solitárias, ca. 4,6 cm diâm.; brácteas verticiladas, ovadas a ovado-lanceoladas; hipanto campanulado; sépalas membranáceas, lanceoladas a oblongas; pétalas oblongas, verde-azuladas a brancas; corona em 5 séries, bandeada de alvo e vinácea. Bagas globosas, verde-amareladas, 2,5-3,1 cm compr.

Material selecionado: BRASIL. São PaUlo: São Paulo, Parque Estadual das Fontes do Ipiranga, 13-IX-1935, F.C. Hoehne s.n. (SP33442).

20.11. Passiflora truncata Regel, Ann. Sci. Nat. 4, Bot. 12: 378. 1859.

Trepadeira herbácea, preensil, gavinha axilar simples. Ramos subtriangulares, pubérulos. Folhas simples, alternas, 3-lobadas; lâmina 4,87,5 × 4,2-6 cm, membranácea; ápice truncado; margem inteira; base arredondada; face adaxial glabra; face abaxial pubérula; venação actinódroma; 3-nervada; pecíolo 1,6-2,2 cm compr., estriado ou canaliculado na face adaxial; 1 par de nectários próximo ao meio, aplanados; estípulas lineares-setáceas; ocelos presentes. Flores 1-2 por nó, 1,7-2,1 cm diâm.; brácteas dispersas; setáceas; hipanto pateliforme; sépalas membranáceas, oblongas, verdes; pétalas alvas; corona em 2 séries, alvas. Bagas arredondadas, 2,2-2,7 cm diâm.

Material selecionado: BRASIL. São PaUlo: São Paulo, Parque Estadual das Fontes do Ipiranga, XII-1954, O. Handro 420 (SP).
20.12. Passiflora villosa Vell., F1. flum. Icon. 9: 87. 1825.

Trepadeira herbácea, preensil, gavinha axilar simples. Ramos cilíndricos, pilosidade amarelada, hirsuto-vilosa. Folhas simples, alternas, 3-lobadas; lâmina 5,8-8,6 × 5,4-7 cm, hastado-cordada, pubescente, membranácea; ápice agudo a obtuso; base cordada; ocelos ausentes; venação actinódroma, 3-nervada; pecíolo 0,6-1,4 cm compr.; estípulas membranáceas oval-lanceoladas. Flores 1-2 por nó, 4,5-5 cm diâm.; brácteas verticiladas, oval-lanceoladas; hipanto obcônico; sépalas oblongas, alvas externamente; corona em 3 séries, filiformes; externamente bandeadas de alva e vinácea. Bagas arredondadas, amareladas, 2,5-3,5 cm diâm.

Material selecionado: BRASIL. São PaUlo: São Paulo, Parque Estadual das Fontes do Ipiranga, 19-IX-1932, F.C. Hoehne s.n. (SP15636).

Ilustração em Bernacci (2003).

\section{PHYTOLACCACEAE}

21.1. Seguieria americana L., Syst. Nat. (ed. 10) 2: 1074. 1759.

Trepadeira lenhosa, escandente. Ramos estriados, sulcados, tomentosos a glabros, armados; lenticelas projetadas. Folhas simples, alternas; lâmina 4,8-10,8 × 1,2-4,7 cm, elíptica a oval; ápice mucronulado; margem inteira, ondulada; base atenuada; venação broquidódroma, glabra; estípulas modificadas em acúleos, uncinado-recurvadas. Inflorescências em racemos terminais ou axilares, 3-24,8 cm compr., tomentosa; brácteas basais 1-2,5 × 1,1-2 mm, imbricadas, ovais; flores alvo-esverdeadas; pedicelo 0,5-0,7 cm, tépalas externas 2, elípticas, internas 3 , obovais. Sâmaras esverdeadas quando maduras.

Material selecionado: BRASIL. São PaUlo: Parque Estadual das Fontes do Ipiranga, X-2007, B.L.P. Villagra 226 (SPw2228).

Observações: a identificação desta espécie, que é nova ocorrência para o PEFI, foi possível através da análise macroscópica do lenho.

\section{POLYGALACEAE}

22.1. Bredemeyera autranii Chodat, Bull. Herb. Boissier 2: 172. 1894.

Trepadeira lenhosa, escandente. Ramos cilíndricos, 
não descamantes, glabros, inermes. Folhas simples, alternas; lâmina 6-8 × 2-4 cm, elíptica ou obovada, glabra ou nervura central da face abaxial pubérula, coriácea; ápice agudo, acuminado ou levemente cuspidado; margem inteira; base aguda a longamente cuneada; venação eucamptódroma; nectários ausentes; pecíolo 4-8 mm compr. Inflorescências em panículas terminais, $15-20 \mathrm{~cm}$ compr., pubérulas a glabrescentes; bractéolas persistentes; flores 4-5 mm compr., alvas; cálice 5 lobado; corola dialipétala, 3-mera, carena ungüiculada. Cápsulas 1,4-1,6 cm compr., pubérulas na base, amarelo-seríceas.

Material selecionado: BRASIL. São Paulo: São Paulo, Parque Estadual das Fontes do Ipiranga, 25-II-1931, F.C. Hoehne s.n. (SP30311).

22.2. Diclidanthera laurifolia Mart., Nov. Gen. sp. pl. 2(2): 141, t. 197. 1827.

Figura 37

Trepadeira lenhosa, escandente. Ramos cilíndricos, ferrugíneo-tomentoso a glabrescentes. Folhas simples, alternas; lâmina 3,4-9,6 × 1,5-3,2 cm, elíptica, estreitamente obovada, pubérula, cartácea; ápice agudo, obtuso a arredondado, às vezes acuminado; margem inteira; base aguda a longamente cuneada; venação broquidódroma; pecíolo 3-6 mm compr., 2 glândulas laterais na base. Inflorescências em racemos terminais ou axilares, 4-8 cm compr., ferrugíneo-tomentosos a glabrescentes; bractéolas caducas; flores 1,5-1,8 cm compr., alvas ou alvo-amareladas; cálice 5 lobado; corola gamopétala, tubulosa-infundibuliforme, 5-mera, 1,3-1,5 cm compr. Bagas globosas.

Material selecionado: BRASIL. São PaUlo: São Paulo, Parque Estadual das Fontes do Ipiranga, 27-IX-2007, B.L.P. Villagra 207 (SP).

Ilustração em Marques \& Gomes (2002).

22.3. Polygala lancifolia A. St.-Hil \& Moq., Mém. Mus.Hist. Nat. Paris 17: 326. 1828.

Trepadeira herbácea, escandente. Ramos cilíndricos, não descamantes, inermes, glabros. Folhas simples, alternas; lâmina 1,5-5,5 × 0,5-1,2 cm, oval, lanceolada até estreitamente lanceolada, glabra; ápice e base agudos a obtusos; margem inteira; venação eucamptódroma; nectários ausentes; ócreas ausentes. Inflorescências em racemos terminais, raramente axilares; flores 2-3 mm compr., alvas, esverdeadas a amareladas; corola dialipétala; pétalas 3 , ápice da carena cristada, crista com 3-4 pares de lobos. Cápsulas aladas, cálice persistente.

Material selecionado: BRASIL. São PaUlo: São Paulo, Parque Estadual das Fontes do Ipiranga, 1-XI-1966, T. Sendulsky 418 (SP).

22.4. Securidaca lanceolata A. St.-Hil \& Moq., Mém. Mus. Hist. Nat. 17: 329. 1828.

Trepadeira lenhosa, escandente. Ramos cilíndricos, não descamantes, inermes, glabros. Folhas simples, alternas; lâmina 2,2-6 × 1,2$3 \mathrm{~cm}$, estreitamente elíptica a elíptica, cartácea a membranácea, glabra; face adaxial pubérula a opaca; face abaxial adpresso-pubescente; ápice e base agudos a obtusos; margem inteira; venação eucamptódroma; nectários ausentes. Inflorescências em racemos terminais; flores $0,8-1 \mathrm{~cm}$ compr., róseas a purpúreas; cálice 5 lobado, em 2 verticilos; corola 5-mera, pétalas 3 , carena cristada, crista flabelado-plicada. Sâmara alada dorsalmente.

Material selecionado: BRASIL. São PaUlo: São Paulo, Parque Estadual das Fontes do Ipiranga, 27-XI-1934, F.C. Hoehne s.n. (SP34019).

\section{POLYGONACEAE}

23.1. Coccoloba arborescens (Vell.) R.A. Howard, Journ. Arn. Arb. 41: 44. 1960.

Trepadeira lenhosa, escandente. Ramos estriados; não descamantes, castanhos, inermes, glabros. Folhas simples, alternas; lâmina 15-20 × 5,5-8 cm, oblongo-obovada, glabra, cartácea; ápice obtuso, curto acuminado; margem inteira; base aguda; venação broquidródoma; nervuras proeminentes, 8-15 pares; ócrea $1-1,5 \mathrm{~cm}$, geralmente fissurada até próximo à base, glabra, coriácea; pecíolo 1,2-1,7 cm compr., glabro, inserido na base ou pouco acima da base da ócrea. Inflorescências em tirsos, densifloros, 13-20 cm compr.; flores pistiladas, 2-3 mm compr.; hipanto campanulado; estigmas lobados; nectários presentes.

Material selecionado: BRASIL. São PAulo: São Paulo, Parque Estadual das Fontes do Ipiranga, 26-IX-1931, F.C. Hoehne s.n. (SP28287); 5-V-2006, B.L.P. Villagra 248 (SP), Lenho (SPw2235). 
Observações: nova ocorrência para o PEFI, segundo Melo (2003) C. arborescens cresce como trepadeira, nunca formando árvores como Coccoloba warmingii Meisn.

Ilustração em Melo (2003).

\section{RUBIACEAE}

24.1. Chiococca alba (L.) Hitchc.,Annual Rep. Missouri Bot. Gard. 4: 94. 1893.

Trepadeira lenhosa, escandente. Ramos estriados, inermes, glabros. Folhas simples, opostas; lâmina 4,1-6,3 × 1,9-3,6 cm, oval a elíptica, glabra, cartácea; ápice agudo a acuminado; margem inteira; base aguda a obtusa; venação broquidódroma; pecíolo 2-7 mm compr., canaliculado na face adaxial, glabro; estípulas interpeciolares, 2-laciniadas, bainha 1-2 mm compr., lacínias 1-2,5 mm compr. Inflorescências em racemos, dispostas unilateralmente nos ramos da inflorescência; corola 6-12 mm compr., amarela a creme. Drupas globosas, 5-7 mm diâm., brancas.

Material selecionado: BRASIL. São Paulo: São Paulo, Parque Estadual das Fontes do Ipiranga, 6-II-1965, O. Handro 1114 (SP).

Ilustração em Jung-Mendaçolli (2007).

\subsection{Emmeorhiza umbellata (Spreng.) K. Schum. in} Mart., Fl. bras. 6(6): 408. 1889.

Trepadeira lenhosa, escandente. Ramos lisos a estriados, inermes. Folhas simples, opostas; lâmina $5-10,2 \times 1,6-2,9 \mathrm{~cm}$, oval a elíptica, cartácea; face adaxial glabra; face abaxial pubérula; ápice atenuado; margem inteira; base atenuada; venação eucamptódroma; pecíolo 4-11 mm compr., canaliculado na face adaxial, glabro; estípulas interpeciolares, 6-10 laciniadas, bainha 4-7 mm compr., lacínia central 2-3 mm compr. Inflorescências em tirsos terminais; corola 3-4 mm compr., alva a creme. Cápsulas sub-globosas, 4-5 mm diâm.

Material selecionado: BRASIL. São PaUlo: São Paulo, Estadual das Fontes do Ipiranga, 2-IV-1974, J.S. Silva 264 (SP).

Ilustração em Jung-Mendaçolli (2007).

24.3. Manettia gracilis Cham. \& Schltdl., Linnaea 4: 169. 1829.

Trepadeira herbácea, volúvel. Ramos lisos, glabros.
Folhas simples, opostas; lâmina 5-6,5 × 1,5-2,5 cm, oval-lanceolada ou oval-oblonga; ápice agudoacuminado; base rotundada ou subcordiforme; venação broquidródoma; pecíolo $0,5-0,8 \mathrm{~cm}$ compr.; estípulas interpeciolares ca. $2 \mathrm{~mm}$ compr.; nectários ausentes. Inflorescências em dicásios; flor axilar, longistila, cálice com lobos subulados e ápice agudo; corola tubulosa-claviforme, 2,5-3,8 cm compr., vermelha, lobos oval-triangulares, externamente glabras, internamente com papilas delicadas. Cápsulas subglobosas.

Material selecionado: BRASIL. São Paulo: São Paulo, Estadual das Fontes do Ipiranga, 8-VIII-1979, A. Custodio Filho 123 (SP).

\subsection{Manettia luteo-rubra (Vell.) Benth., Linnaea} 23: 445. 1850.

Trepadeira herbácea, volúvel; látex ausente. Ramos lisos, glabros. Folhas simples, opostas; lâmina 7,5-10 × 2,5-3,5 cm, lanceolada ou oblongo-lanceolada; ápice e base atenuado-acuminados; venação broquidródoma; pecíolo 1,5-2 cm compr.; estípulas interpeciolares ca. $3 \mathrm{~mm}$ compr.; nectários ausentes. Inflorescências em dicásios reduzidos, flor axilar, heterostílica, brevistila, longistila; cálice foliáceo com ápice atenuado-acuminado; corola tubulosa, cilíndrica, vermelha, pubérula externamente, lobos triangulares amarelos. Cápsulas, clavado-globosas.

Material selecionado: BRASIL. São Paulo: São Paulo, Parque Estadual das Fontes do Ipiranga, 10VIII-1967, R. Faria 29 (SP).

\section{SAPINDACEAE}

25.1. Paullinia carpopoda Cambess. in A. St.-Hil., Fl. bras. merid. 1: 376. 1825.

Figura 38

Trepadeira lenhosa, preensil; gavinhas 2, na base da inflorescência. Corpo lenhoso simples, látex e resina não observados; ramos simples, glabros. Folhas alternas, pinadas, 3-jugas; folíolos 2,5-9,5 × 0,7-3,1 cm, sésseis a subsésseis, elíptico-lanceolados, glabros, os basais geralmente ternados; ápice obtusamente acuminado, mucronado; margem inteira; venação actinódroma; raque alada. Inflorescências em tirsos axilares ou terminais; flores brancas, ca. 5,0 mm diâm. Cápsulas globosas, longamente estipitadas, externamente glabras, ca. $1 \mathrm{~cm}$ compr. Sementes pretas, arilo branco. 
Material selecionado: BRASIL. São Paulo: São Paulo, Parque Estadual das Fontes do Ipiranga, 12-IV-2006, B.L.P. Villagra 84 (SP).

Ilustração em Reitz (1980).

25.2. Paullinia micrantha Cambess. in A. St.-Hil., Fl. bras. merid. 1: 373. 1825.

Trepadeira lenhosa, preensil; gavinhas 2, na base da inflorescência. Corpo lenhoso simples, resina vermelha; ramos cilíndricos, estriados, pubescentes quando jovens, posteriormente pubérulos. Folhas alternas, pinadas, 2-ternadas; folíolos 1,5-4,5 × 0,8-1,5 cm, foliólulos sésseis, cartáceos, terminal sub-romboidal a oval, ápice agudo, margem serreada na metade superior, base atenuada a aguda; os laterais elípticos, ápice agudo, margem serreada, base aguda; pubescentes nas nervuras; face abaxial com domácias nas axilas da nervura principal; venação craspedódroma mista; pecíolo 1,1-3 cm compr., canaliculado na face adaxial, pubescente. Inflorescências em tirsos axilares; flores alvas, 2-3 mm compr. Cápsulas trígonas a trialadas, 9-12 × 6-9 mm, vermelhas, deiscentes. Sementes pretas, arilo branco.

Material selecionado: BRASIL. São PAUlo: São Paulo, Parque Estadual das Fontes do Ipiranga, 22-I-1935, O. Handro s.n. (SP32381).

Ilustração em Reitz (1980).

25.3. Paullinia seminuda Radlk., Monogr. Serjania: 47. 1875.

Figura 39

Trepadeira lenhosa, preensil; gavinhas 2, na base da inflorescência. Corpo lenhoso simples, resina vermelha, ramos estriados, pubescentes. Folhas alternas, pinadas, 2-jugas; folíolos 5-18 × 2,3-5,5 cm, curtamente peciolulados, lanceolados a oval-lanceolados; nervuras estrigosas; ápice acuminado, mucronulado; margem serreada; base atenuada; venação craspedódroma; raque alada. Inflorescências em tirsos axilares; flores alvo-esverdeadas, ca. $5 \mathrm{~mm}$ diâm. Cápsulas globosas, curtíssimamente estipitadas, externamente tomentosas. Sementes pretas, arilo branco.

Material selecionado: BRASIL. São PAUlo: São Paulo, Parque Estadual das Fontes do Ipiranga, 27-X-2006, B.L.P. Villagra 161 (SP).

Ilustração em Cruz et al. (1989).
25.4. Serjania caracasana (Jacq.) Willd., Sp. Pl. 2(1): 465. 1799.

Trepadeira lenhosa, preensil; gavinhas 2, na base da inflorescência. Corpo lenhoso composto por 1 cordão central e 4-6 periféricos, látex branco. Folhas alternas, 2-ternadas; foliólulos 2,5-10,4 × 1,3-3,3 cm, lanceolados, elíptico-lanceolados a oval-lanceolados; na face abaxial domácias em tufo nas axilas das nervuras secundárias; ápice agudo; margem serreada; base cuneada; venação craspedódroma. Inflorescências em tirsos axilares; flores alvas, ca. $5 \mathrm{~mm}$ diâm. Samarídeos 3.

Material selecionado: BRASIL. São PAUlo: São Paulo, Parque Estadual das Fontes do Ipiranga, 4-VI-1980, M.M.R.F. Melo \& S.L. Jung 232 (SP).

25.5. Serjania communis Cambess. in A. St.-Hil., Fl. bras. merid. 1: 362.1827 (1828).

Trepadeira lenhosa, preensil; gavinhas 2, na base da inflorescência. Corpo lenhoso composto por 1 cordão central e 3 periféricos, látex não observado. Folhas alternas, 2-ternadas; foliólulos 1-9,5 × 0,7-3 cm,lanceolados, oval-lanceolados, sésseis, cartáceos; face abaxial destituída de domácias; ápice agudo, mucronulado; margem serreado-dentada; base cuneada, longamente cuneada nos foliólulos apicais; venação broquidródoma inconspícua. Inflorescências em tirsos axilares; flores alvas ou cremes, ca. 5,0 mm diâm. Samarídeos 3, alas castanhas a avermelhadas, 2,8-3,4 cm compr.

Material selecionado: BRASIL. São PaUlo: São Paulo, Parque Estadual das Fontes do Ipiranga, 27-X-2005, B.L.P. Villagra 12 (SP).

25.6. Serjania gracilis Radlk., Monogr. Serjania: 134. 1875.

Trepadeira lenhosa, preensil; gavinhas 2, na base da inflorescência. Corpo lenhoso simples, ramos angulosos, sulcados, pubérulos a glabros, látex não observado. Folhas alternas, 2-ternadas; folíolos sésseis a subsésseis; foliólulos 1,5-9 × 0,8-2,8 cm, elípticos a lanceolados, cartáceos; face adaxial glabra; face abaxial pubescente a pubérulo; ápice agudo, mucronulado; margem inteira; base aguda; venação broquidódroma. Inflorescências em tirsos axilares; flores alvas a cremes, 2-3 mm. Samarídeos 3.

Material selecionado: BRASIL. São Paulo: São Paulo, Parque Estadual das Fontes do Ipiranga, 6-V-1985, S. Romaniuc Neto 260 (SP). 
25.7. Serjania lethalis A. St.-Hil., Pl. Rem. Bres. 1: 206. 1824.

Figura 40

Trepadeira lenhosa, preensil; gavinhas 2, na base da inflorescência. Corpo lenhoso composto por 1 cordão central e 3 periféricos, látex não observado. Folhas alternas, 2-ternadas; foliólulos 3-11 × 1,7-3,3 cm, elípticos a lanceolados, subsésseis; face abaxial destituída de domácias; ápice longamente acuminado; margem inteira, os laterais curtamente serreados; base longamente cuneada; venação broquidódroma inconspícua. Inflorescências em tirsos axilares; flores alvas a amareladas, ca. $8 \mathrm{~mm}$ diâm. Samarídeos 3, pouco cristados no ápice, núcleo seminífero muito saliente, alvo-tomentoso, 3-3,5 cm compr.

Material selecionado: BRASIL. SÃo Paulo: São Paulo, Parque Estadual das Fontes do Ipiranga, 6-II-2006, B.L.P. Villagra 48 (SP).

25.8. Serjania multiflora Cambess. in A. St.-Hill., Fl. Bras. Merid 1: 365. 1828.

Trepadeira lenhosa, preensil; gavinhas 2, na base da inflorescência. Corpo lenhoso composto por 1 cordão central e 8 periféricos, estriados, látex ausente. Folhas alternas, 2-ternadas; foliólulos 2,6-8,5 × 1,2-3,7 cm, lanceolados, obovado-lanceolados; face abaxial nitidamente reticulado-venosa; domácias ausentes; ápice agudo, mucronulado; margem serreado-dentada; base longamente cuneada; venação craspedródoma. Inflorescências em tirsos axilares; flores alvas a amareladas, ca. $6 \mathrm{~mm}$ diâm. Samarídeos 3, pouco cristados no ápice, núcleo seminífero saliente, fulvo-tomentoso, 2, 6-2,9 cm compr.

Material selecionado: BRASIL. São PaUlo: São Paulo, Parque Estadual das Fontes do Ipiranga, 27-X-2005, B.L.P. Villagra 11 (SP).

25.9. Serjania reticulata Cambess. in A. St.-Hill., Fl. bras. merid. 1: 359. 1827. Figura 41

Trepadeira lenhosa, preensil; gavinhas 2, na base da inflorescência. Corpo lenhoso simples, ramos lisos, estriados, látex não observado. Folhas alternas, 2-ternadas; foliólulos 1,3-8,5 × 0,8-4 cm, peciolulados, ovais a oval-lanceolados; face abaxial destituída de domácias; ápice agudo, mucronulado; margem esparsamente serreada; base obtusa, estreitando abruptamente em peciólulo; venação craspedródoma.
Inflorescências em tirsos axilares; flores alvas a amareladas, ca. 7 mm diâm. Samarídeos 3, asas pouco a não constritas abaixo do núcleo seminífero, núcleo seminífero bastante saliente, glabro, 1,8-2,5 cm compr.

Material selecionado: BRASIL. São PAUlo: São Paulo, Parque Estadual das Fontes do Ipiranga, 8-III2006, B.L.P. Villagra 31 (SP).

25.10. Thinouia ventricosa Radlk., Atti Congr. Bot. Firenze 61. 1874.

Trepadeira lenhosa, preensil; gavinhas 2, na base da inflorescência. Corpo lenhoso composto por 1 cordão central e 3-8 periféricos, látex e resina não observados. Folhas alternas, 3 folioladas; folíolos $3,5-8 \times 1,7-3,1 \mathrm{~cm}$, sésseis a curtamente peciolulados, oval-lanceolados, glabros; ápice subacuminado, mucronulado; margem inteira a esparsamente denticulado, subrepanda; base cuneada; venação eucamptódroma. Inflorescências em tirsos corimbiformes axilares, ca. 2,5 cm compr.; flores alvas; sépalas 5, esparsamente pilosas na margem; pétalas 5 , dobro do comprimento das sépalas, internamente limbo ventral pubescente, disco lobado. Samarídeos 3, núcleo seminífero inflado na base do samarídeo.

Material selecionado: BRASIL. São Paulo: São Paulo, Parque Estadual das Fontes do Ipiranga, 6-I1940, F.C. Hoehne s.n. (SP40161).

\section{SMILACACEAE}

26.1. Smilax elastica Griseb. in Mart., Fl. bras. 3(1): 22. 1842.

Figura 42

Trepadeira herbácea, preensil; gavinhas 2, na bainha foliar. Ramos cilíndricos, lisos, estriados, acúleos nos entrenós, catafilos não inclusos no profilo. Folhas simples, alternas; lâmina 5-12 $\times$ 2-5,5 cm, lanceolada ou ovado-lanceolada, crassocoriácea; ápice agudo, apiculado; base aguda, arredondada ou subcordada; opaca em ambas as faces; castanha quando seca; venação acródroma; nervuras proeminentes na face adaxial e impressas na face abaxial; 5-nervadas, a central mais espessa que as duas laterais; pecíolo 0,7-1 cm compr. Inflorescências em cimeiras de umbelas; flores estaminadas esverdeadas, pedúnculo e pedicelo 3-9 mm compr.; botões florais elípticos; nas tépalas manchas ferrugíneas; flores pistiladas esverdeadas, pedúnculos 2,5-6 mm compr., pedicelos 4-8 $\mathrm{mm}$ compr.; tépalas externas ovadas, 
ca. 2 mm compr., internas elípticas, máculas ferrugíneas, ca. 1,8 mm compr.; estaminódios 6 , filiformes. Bagas 3-9 mm diâm., pedicelo 4-9 mm compr., pedúnculo da infrutescência 1-6 mm compr.

Material selecionado: BRASIL. São PAUlo: São Paulo, Parque Estadual das Fontes do Ipiranga, 12-IV-2006, B.L.P. Villagra 82 (SP).

26.2. Smilax quinquenervia Vell., F1. flumin. 10: tab. 108. 1831.

Trepadeira herbácea, preensil; gavinhas 2, na bainha foliar. Ramos cilíndricos, lisos, armados, glabros, acúleos nos entrenós, robustos, 5-7 mm compr., catafilos inclusos no profilo. Folhas simples, alternas; lâmina 14-23 × 5-11 cm, oval a lanceolada, glabra, papirácea; ápice agudo a atenuado, apiculado; margem inteira; base arredondada a aguda; enegrecidas quando secas; venação acródroma; 5-nervadas, proeminentes em ambas as faces; pecíolo 1,5-2,4 cm compr., canaliculado, glabro. Inflorescências em cimeiras de umbelas; flores estaminadas esverdeadas a pretas, tépalas diferentes entre si; flores pistiladas esverdeadas a pretas, axilares, tépalas externas semelhantes entre si, 4-5 mm compr. Bagas piriformes, 12-17 mm compr., amarelados a alaranjados.

Material selecionado: BRASIL. SÃo PAULO: São Paulo, Parque Estadual das Fontes do Ipiranga, 27-VI-2007, B.L.P. Villagra \& A. C. Laurenti 173 (SP).

Ilustração em Andreata (2003).

26.3. Smilax remotinervis Hand.-Mazz., Denkschr. Akad. Wien. Math. Nat. 79(1): 22. 1908.

Trepadeira herbácea, preensil, gavinhas 2, na bainha foliar. Ramos subcilíndricos, verrucosos ou lisos, estriados, armados, acúleos esparsos, claros, ápices escurecidos, uncinados, 1-1,5 mm compr.; catafilos coriáceos, lisos, agudos, $1 \mathrm{~cm}$ compr. Folhas simples, alternas; lâmina 10-15,5 × 2-4,5 cm, lanceolada, rígido-papirácea, verde-acizentadas quando secas; ápice agudo, apiculado; base cuneada; venação acródroma, 5-nervadas; nervuras proeminentes, a central mais espessa que as duas laterais; margens espessadas; pecíolos estriados, escuros quando secos, bainha estriada. Inflorescências em cimeiras de umbelas; flores estaminadas vináceas, pedúnculos estriados; botões florais oblongos, tépalas diferentes entre si; flores pistiladas vináceas, pedúnculos verrucosos; botões florais ovais, tépalas semelhantes entre si, 3 estaminódios. Bagas imaturas, 6-9 mm diâm.
Material selecionado: BRASIL. São Paulo: São Paulo, Parque Estadual das Fontes do Ipiranga, 2-VII-1979, A. Custodio Filho 20 (SP).

Ilustração em Andreata (2003).

26.4. Smilax staminea Griseb. in Mart., Fl. bras. 3(1): 11. 1842.

Trepadeira herbácea, preensil, gavinhas 2, na bainha foliar. Ramos cilíndricos, lisos, inermes. Folhas simples, alternas; lâmina 6-11 × 1,5-6 cm, ovada ou ovado-lanceolada, rígido-papirácea, ferrugíneo-esverdeada quando seca; face adaxial opaca; face abaxial lúcida; ápice caudado; base atenuada; venação acródroma, nervuras proeminentes em ambas as faces; nervura central mais espessa que as duas laterais; pecíolos 0,6-1,2 cm compr. Inflorescências em cimeiras de umbelas, estaminadas pedunculadas; botões florais elípticos ou obovados; tépalas maculadas, ferrugíneas, margens mais claras; pedúnculos ca. $2 \mathrm{~mm}$ compr.; botões florais elípticos ou obovados; tépalas maculadas ou não, ferrugíneas; Inflorescências pistiladas, pedúnculo 0,2-1 cm compr.; botões florais ovóide-oblongos; tépalas oblongas ca. $3 \mathrm{~mm}$ compr. Bagas 0,9-1,3 cm diâm.

Material selecionado: BRASIL. São PAulo: São Paulo, Parque Estadual das Fontes do Ipiranga, 16-X-1944, F.C. Hoehne s.n. (SP27183).

\section{SOLANACEAE}

27.1. Solanum inodorum Vell., Fl. flum. 85. 1829. Figura 43

Trepadeira herbácea, volúvel, aromática. Ramos glabros. Folhas simples, alternas; lâmina 6-11 × 2,5-4 cm, elíptica, glabra, cartácea; ápice acuminado; base obtusa ou arredondada; pecíolo retorcido, ca. $3 \mathrm{~cm}$ compr.; venação actinódroma. Inflorescências em panículas terminais, paucifloras; corola alva ou arroxeada, rotácea, profundamente estrelada; anteras poricidas. Bagas globosas, vermelhas quando maduras.

Material selecionado: BRASIL. São PAUlo: São Paulo, Parque Estadual das Fontes do Ipiranga, 8-III-2005, B.L.P. Villagra 52 (SP).

\section{TRIGONIACEAE}

28.1. Trigonia nivea Cambess., Fl. bras. merid. 2: 113. 1829.

Trepadeira herbácea, escandente. Ramos jovens 

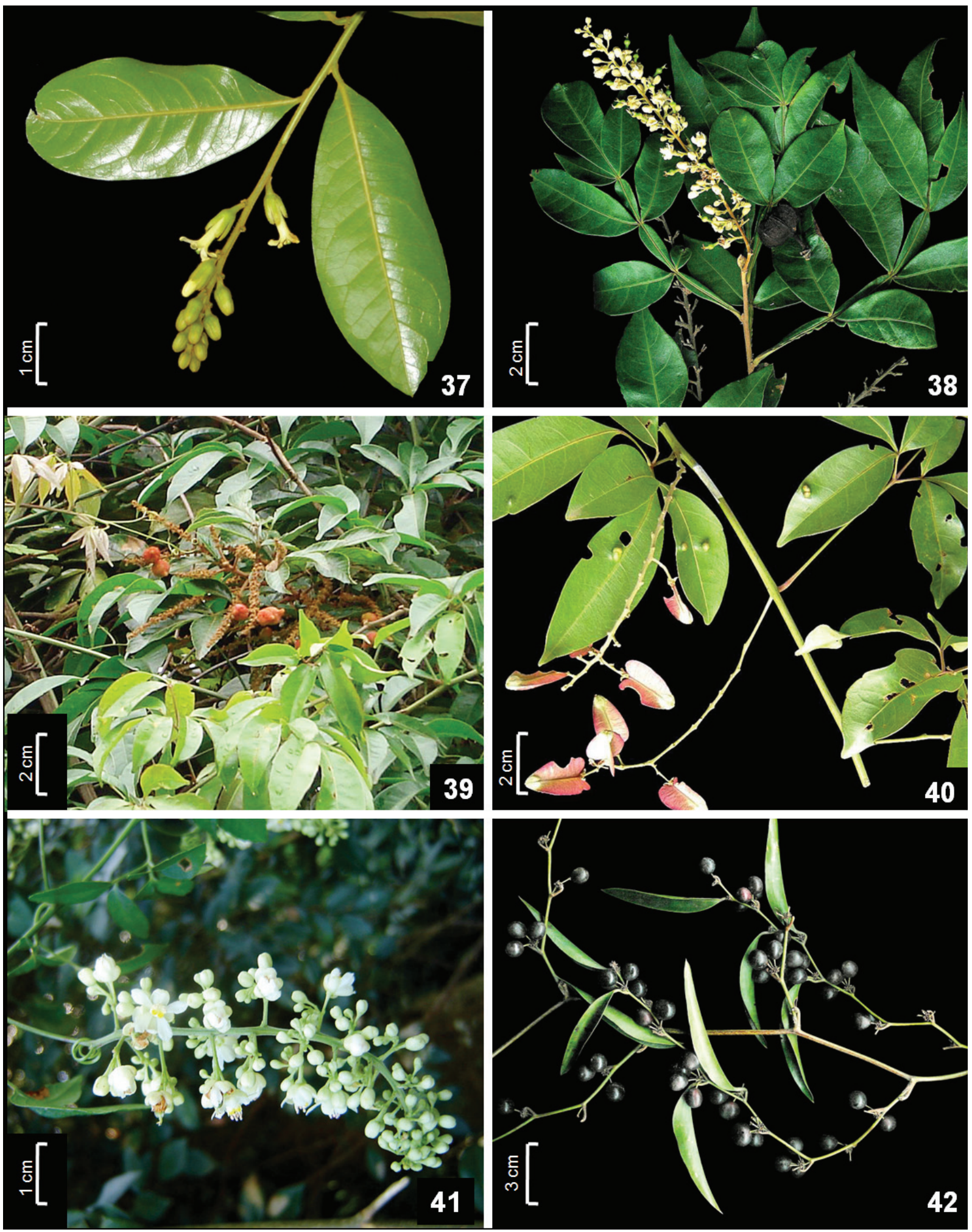

Figura 37-42. Polygalaceae. 37. Diclidanthera laurifolia. Sapindaceae. 38. Paullinia carpopoda. 39. Paullinia seminuda. 40. Serjania lethalis. 41. Serjania reticulata. Smilacaceae. 42. Smilax elastica Griseb.

Figure 37-42. Polygalaceae. 37. Diclidanthera laurifolia. Sapindaceae. 38. Paullinia carpopoda. 39. Paullinia seminuda. 40. Serjania lethalis. 41. Serjania reticulata. Smilacaceae. 42. Smilax elastica Griseb. 
pubescentes esbranquiçados, inermes. Folhas simples, opostas; lâmina 8,5-11,5 × 2,5-2,8 cm, lanceolada, elíptica, oval ou oboval; face adaxial glabra; face abaxial estrigosa, pilosidade esbranquiçada; venação actinódroma; estípula interpeciolar caduca. Inflorescências em tirsos, multifloras; flor 0,5-1,2 cm compr. Cápsulas septicidas, 5,3-13,5 cm compr., estrigosas.

Material selecionado: BRASIL. São PAUlo: São Paulo, Parque Estadual das Fontes do Ipiranga, 12-I-1932, F.C. Hoehne s.n. (SP303548).

28.2. Trigonia paniculata Warm. in Mart., Fl. bras. 13(2): 132. 1875.

Figura 44

Trepadeira lenhosa, escandente. Ramos jovens pubescentes esverdeados, inermes. Folhas simples, opostas; lâmina 5,4-6,5 × 1,8-2,4 cm, oblonga a elíptica, pilosidade olivácea, membranácea, face adaxial pubescente nas nervuras; face abaxial pubescente; ápice acuminado; base atenuada; venação actinódroma; estípula interpeciolar caduca. Inflorescências em tirsos, acima de 80 flores, amarelas, flor 0,3-0,5 cm compr. Cápsulas septicidas, multisseminadas.

Material selecionado: BRASIL. São Paulo: São Paulo, Parque Estadual das Fontes do Ipiranga, 11-XII-2006, B.L.P. Villagra 141 (SP).

\section{VALERIANACEAE}

29.1. Valeriana scandens L., Sp. pl. ed. 2: 47. 1762.

Trepadeira herbácea, volúvel. Ramos lisos, pubérulos. Folhas opostas, 3 folioladas; folíolo central 1,8-6,5 × 1,5-3 cm, lobos laterais assimétricos; ovais, pubérulos, membranáceos; ápice acuminado, margem denteada, base cordada; venação eucamptódroma. Inflorescências em dicásio; flores 5-meras; lobos do cálice expandindo-se em pápus plumoso nos frutos; corola alvo-amarelada. Cipselas aladas, 6-10 × 2-3,7 mm.

Material selecionado: BRASIL. São Paulo: São Paulo, Parque Estadual das Fontes do Ipiranga, 28-VII-2006, B.L.P. Villagra 109 (SP).

Ilustração em Scalon et al. (2002).

\section{VERBENACEAE}

\subsection{Petrea volubilis L., Sp. pl. 2: 626. 1753.}

Trepadeira herbácea, escandente. Ramos cilíndricos, pubescentes, inermes. Folhas simples, opostas; lâmina 7-8,5 ×2,5-3,5 cm, elíptica, glabra, membranácea; ápice obtuso; margem serrilhada, ondulada, base obtusa; venação eucamptódroma; estípulas ausentes. Inflorescências em racemos axilares; cálice levemente 5-lobado, epicálice 5 lobado, lobo linear, reticulado, brevemente acuminado; corola 5-lobada, internamente pubérula. Drupa globosa.

Material selecionado: BRASIL. São Paulo: São Paulo, Parque Estadual das Fontes do Ipiranga, 5-X-1931, F.C. Hoehne s.n. (SP28316).

\section{VIOLACEAE}

31.1. Anchietea pyrifolia (Mart.) G. Don, Gen. Syst. 1: 340.1831.

Trepadeira lenhosa, escandente. Ramos cilíndricos, glabros, entrenós 0,5-3,2 cm compr., não descamantes, inermes. Folhas simples, alternas; lâmina 1,8-7,9 × 0,5-3,2 cm, elíptica ou lanceolada, glabra; ápice agudo a acuminado; margem serreada; base aguda, obtusa a arredondada; venação broquidródoma inconspícua; nectários ausentes; pecíolo 0,2-0,9 cm compr. Inflorescências em racemos ou fascículos axilares, amarelo-esverdeados; pétala anterior calcarada. Cápsulas vesiculoso-infladas.

Material selecionado: BRASIL. São Paulo: São Paulo, Parque Estadual das Fontes do Ipiranga, 12-VIII-1968, T. Sendulsky 931 (SP).

Ilustrações em Souza \& Souza (2002).

\section{VITACEAE}

32.1. Cissus paullinifolia Vell., Fl. flum. 1: 40, t. 102. 1829.

Trepadeira herbácea, preensil; gavinha mais de 4-ramificada, oposta a folha. Ramos glabros. Folhas alternas, imparipinadas, 5-folioladas; folíolos 4-12 × 2-12,5 cm, lanceolados a oblongo-lanceolados; estípulas deltóides, pubérulas; venação eucamptódroma; pecíolos 4-9 cm compr. Inflorescências em umbelas, 70-80 flores, monóclinas, vermelhas; cálice pubescente na base, arredondada; corola amarela, glabra, $3 \mathrm{~mm}$ compr. Bagas globosas, 5-6 mm diâm.

Material selecionado: BRASIL. São Paulo: São Paulo, Parque Estadual das Fontes do Ipiranga, 6-V-1934, F.C.Hoehne s.n. (SP 28304).

Ilustração em Lombardi (2002). 

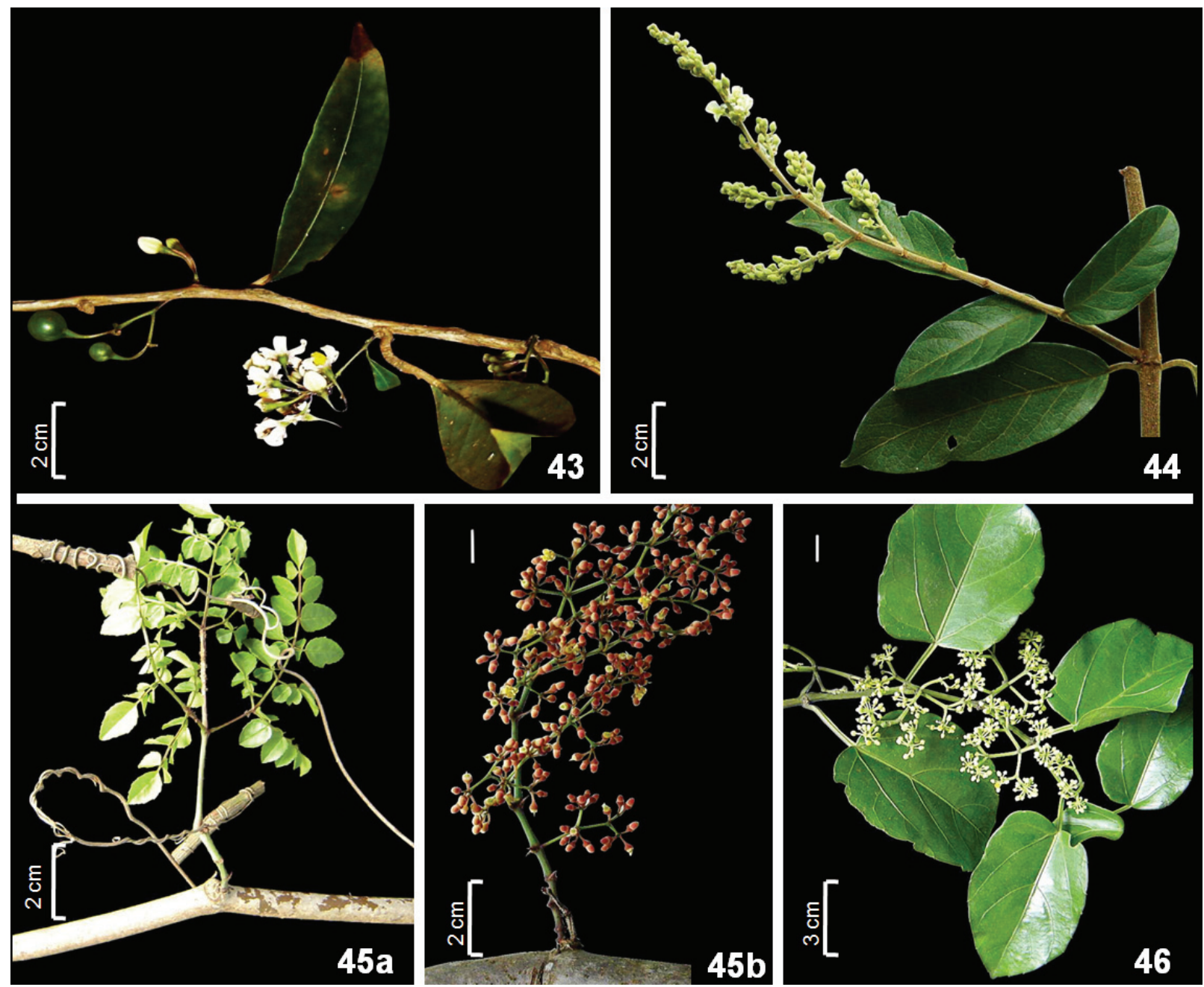

Figura 43-46. Solanaceae. 43. Solanum inodorum. Trigoniaceae. 44. Trigonia paniculata. Vitaceae. 45. Cissus serroniana. a. folha tripinada. b. inflorescência. 46. Cissus verticillata.

Figure 43-46. Solanaceae. 43. Solanum inodorum. Trigoniaceae. 44. Trigonia paniculata. Vitaceae. 45. Cissus serroniana. a. folha tripinada. b. inflorescência. 46. Cissus verticillata.

\subsection{Cissus serroniana (Glaz.) Lombardi, Taxon} 44(2): 200. 1995.

Figura $45 \mathrm{a}, \mathrm{b}$

Trepadeira lenhosa, preensil; gavinha 4-ramificada, oposta à folha. Ramos cilíndricos, estriados, lenticelados, glabros. Folhas alternas, 3-pinadas, ausentes nos ramos reprodutivos; 5 pares de folíolos opostos; folíolos de $1^{\mathrm{a}}$ ordem 1-6 $\times 0,8-5 \mathrm{~cm}$; folíolos de $3^{\mathrm{a}}$ ordem serrilhados, glabros, membranáceos; venação eucamptódroma; estípulas lanceoladas. Inflorescências em panículas, 40-60 flores; monóclinas; botões elipsóides; cálice vermelho; corola amarela; estames amarelos. Bagas globosas, 0,4 cm diâm.
Material selecionado: BRASIL. SÃo PaUlo: São Paulo, Parque Estadual das Fontes do Ipiranga, 12-XII-2006, B.L.P. Villagra 145 (SP).

Observações: nova ocorrência para o PEFI difere das demais espécies de Cissus pelas folhas tripinadas.

Ilustração em Lombardi (2002).

32.3. Cissus sulcicaulis (Baker) Planch. in A. DC. \& C. DC., Monogr. phan. 5(2): 547. 1887.

Trepadeira herbácea, preensil; gavinha simples ou bífida, oposta a folha. Ramos cilíndricos, alados. Folhas alternas, 3 folioladas; folíolos 4,5-9 × 3-8,5, sésseis; terminal rombóide, pubérulos, laterais 
assimétricos; face adaxial pubescente-glandulosa; face abaxial glabra a pubérula; venação actinódroma; estípulas deltóides; pecíolo 3,7-15,6 cm compr. Inflorescências em umbelas, 20-30 flores; flores monóclinas, verde-amareladas, cálice pubérulo, base lobada; corola glabra. Bagas globosas, 3-4 mm diâm.

Material selecionado: BRASIL. São Paulo: São Paulo, Parque Estadual das Fontes do Ipiranga, 13-II-1932, F.C. Hoehne s.n. (SP28795).

\subsection{Cissus verticillata (L.) Nicolson \& C.E. Jarvis,} Taxon 33(4): 727. 1984.

\section{Figura 46}

Trepadeira herbácea, preensil; gavinha simples, oposta a folha; formando ângulo de $90^{\circ}$. Ramos achatados, estriados, glabros. Folhas simples, alternas; lâmina 6-9 × 4,5-6 cm, oval, glabra, membranácea; ápice apiculado; margem serreada; base levemente cordada; venação actinódroma; estípulas falcadas ou ovais; pecíolo $0,5-8 \mathrm{~cm}$ compr. Inflorescências em umbelas axilares; flores monóclinas, 30-50, verde-amareladas; botões elipsóides; cálice glabro, base arredondada; pétalas glabras. Bagas globosas, lisas, ca. $1 \mathrm{~cm}$ diâm.

Material selecionado: BRASIL. São PAulo: São Paulo, Parque Estadual das Fontes do Ipiranga, 27-III-2007, B.L.P. Villagra 199 (SP).

\section{Agradecimentos}

À coordenação do Programa de Pós-Graduação pelo auxílio PROAP concedido. À CAPES pela concessão de bolsa de mestrado a primeira autora. Aos especialistas pelo auxílio nas identificações: Dra Maria Candida H. Mamede (Malpighiaceae), Dra Rosângela Simão-Bianchini (Convolvulaceae), Dra Mizué Kirizawa (Dioscoreaceae), Dra Maria das Graças Wanderley (Smilacaceae), Dra Cintia Kameyama (Acanthaceae), Dra Lúcia Rossi, MSc Fátima O. Souza e MSc Sônia Aragaki.

\section{Literatura citada}

Andreata, R.H.P. 2003. Smilacaceae. In: M.G.L. Wanderley, G.J. Shepherd, T.S. Melhem, A.M. Giulietti \& M. Kirizawa (eds.). Flora Fanerogâmica do Estado de São Paulo. FAPESP/ Rima, São Paulo, v. 3, pp. 323-332.
APG II. The Angiosperm Phylogeny Group. 2003. An update of the Angiosperm Phylogeny Group classification for the orders and families of flowering plants. Botanical Journal of the Linnean Society 141: 399-436.

Arbo, M.M. \& Lohmann, L. 2008. Bignoniaceae. In: F.O. Zuloaga, O. Morrone \& M.J. Belgrano, (eds.) Monographs in Systematic Botany from the Missouri Botanical Garden 107(2): 1581-1626.

Bernacci, L.C. 2003. Passifloraceae. In: M.G.L. Wanderley, G.J. Shepherd, T.S. Melhem, A.M. Giulietti \& M. Kirizawa (eds.). Flora Fanerogâmica do Estado de São Paulo. FAPESP / Rima, São Paulo, v. 3, pp. 247-274.

Bicudo, D.C., Forti, M.C. \& Bicudo, C.E.M. (orgs.) 2002. Parque Estadual das Fontes do Ipiranga (PEFI): unidade de conservação que resiste à urbanização de São Paulo. Secretaria do Meio Ambiente do Estado de São Paulo, São Paulo.

Brummitt, R.K. \& Powell, C.E. 1992. Authors of plant names. Royal Botanic Gardens, Kew.

Buzato, S. \& Vitta, F. 2005. Mendonciaceae. In: M.G.L. Wanderley, G.J. Shepherd, T.S. Melhem, S.E. Martins, M. Kirizawa \& A.M. Giulietti (eds.). Flora Fanerogâmica do Estado de São Paulo. FAPESP / Rima, São Paulo, v. 4, pp. 273-276.

Capellari Junior, L. 2002. Aristolochiaceae. In: M.G.L. Wanderley, G.J. Shepherd \& A.M. Giulietti, T.S. Melhem, V. Bittrich \& C. Kameyama (eds.). Flora Fanerogâmica do Estado de São Paulo. FAPESP / Hucitec, São Paulo, v. 2, pp. 39-49.

Costa, F.N. \& Sano, P.T. 2007. Menispermaceae. In: T.S. Melhem, M.G.L. Wanderley, S.E. Martins, S.L. Jung-Mendaçolli, G.J. Shepherd \& M. Kirizawa (eds.). Flora Fanerogâmica do Estado de São Paulo. Instituto de Botânica, São Paulo, v. 5, pp. 227-235.

Cruz, M.A.V., Barroso, G.M. \& Barros, F. 1989. Flora Fanerogâmica da Reserva do Parque Estadual das Fontes do Ipiranga (São Paulo, Brasil). 111 - Sapindaceae. Hoehnea 16: 1-10.

Darwin, C. 1867. On the moviments and habits of climbing plants. Journal of the Linnean Society, ser. Botany 9: 1-118.

Engel, V.L., Fonseca, R.C.B. \& Oliveira, R.E. 1998. Ecologia de lianas e o manejo de fragmentos florestais. Série Técnica IPEF 12: 43-64.

Fidalgo, O. \& Bononi, V.L.R. (coords.). 1984. Técnicas de coleta, preservação e herborização de material botânico. (Manual 4) Instituto de Botânica, São Paulo.

Fontella-Pereira, J. 2005. Asclepiadaceae. In: M.G.L. Wanderley, G.J. Shepherd, T.S. Melhem, S.E. Martins, M. Kirizawa \& A.M. Giulietti (eds.). Flora Fanerogâmica do Estado de São Paulo. FAPESP / Rima, São Paulo, v. 4, pp. 93-156. 
Gentry, A.H. 1982. Patterns of neotropical plant species diversity. Evolutionary Biology 15: 1-84.

Gentry, A.H. 1985. An ecotaxonomic survey of Panamanian lianas. In: W.G. D’Arcy \& M. Correa (eds.). Historia Natural de Panama. Missouri Botanical Garden, St Louis, pp. 29-42.

Gentry, A.H. 1991. The distribution and evolution of climbing plants. In: F.E. Putz \& H.A. Mooney (eds.). The Biology of Vines. Cambridge University Press, Cambridge, pp. 3-49.

Hora, R.C. \& Soares, J.J. 2002. Estrutura fitossociológica da comunidade de lianas em uma floresta estacional semidecidual na Fazenda Canchim, São Carlos, SP. Revista Brasileira de Botânica 25: 323-329.

Janzen, D.H. 1980. Ecologia vegetal nos trópicos. Pedagógica e Universitária, São Paulo.

Judd, W.S., Campbell, C.S., Kellogg, E.A. \& Stevens, P. 2002. Botanique Systématique - une perspective phylogénétique. Deboeck Université, Paris.

Jung-Mendaçolli, S.L. 2007. Rubiaceae. In: T.S. Melhem, M.G.L. Wanderley, S.E. Martins, S.L. Jung-Mendaçolli, G.J. Shepherd \& M. Kirizawa (eds.). Flora Fanerogâmica do Estado de São Paulo. Instituto de Botânica, São Paulo, v. 5, pp. 259-460.

Kinoshita, L.S. 2005. Apocynaceae. In: M.G.L. Wanderley, G.J. Shepherd, T.S. Melhem, S.E. Martins, M. Kirizawa \& A.M. Giulietti (eds.). Flora Fanerogâmica do Estado de São Paulo. FAPESP / Rima, São Paulo, v. 4, pp. 35-91.

Kirizawa, M. \& Romanini, R.P. 2003. Dioscoreaceae. In: M.M.R.F. Melo, F. Barros, S.A.C. Chiea, M. Kirizawa, S.L. Jung-Mendaçolli, M.G.L. Wanderley. (eds). Flora Fanerogâmica da Ilha do Cardoso. Instituto de Botânica, São Paulo, v. 10, pp.11-35.

Klein, V.L.G. 2000. Estudos taxonômicos de Cayaponia Silva Manso (Cucurbitaceae) no Brasil. Tese de Doutorado, Universidade de São Paulo, São Paulo.

Kubitzki, K. \& Reitz, P.R. 1971. Dileniáceas. In: R. Reitz (ed.). Flora Ilustrada Catarinense, parte I. Herbário Barbosa Rodrigues, Itajaí, fasc. DILE, pp. 8-15.

Lohmann, L.G. 2010. Bignoniaceae. In: R.C. Forzza, P.M. Leitman, A.F. Costa, A.A. Carvalho Jr., A.L. Peixoto, B.M.T. Walter, C. Bicudo, D. Zappi, D.P. Costa, E. Lleras, G. Martinelli, H.C. Lima, J. Prado, J.R. Stehmann, J.F.A. Baumgratz, J.R. Pirani, L. Sylvestre, L.C. Maia, L.G. Lohmann, L.P. Queiroz, M. Silveira, M.N. Coelho, M.C. Mamede, M.N.C. Bastos, M.P. Morim, M.R. Barbosa, M. Menezes, M. Hopkins, R. Secco, T.B. Cavalcanti, \& V.C. Souza. Lista de Espécies da Flora do Brasil. Jardim Botânico do Rio de Janeiro. http://floradobrasil. jbrj.gov.br/2010/FB112305. (acesso em 05.2011).

Lombardi, J.A. 2002. Vitaceae. In: M.G.L. Wanderley, G.J. Shepherd, A.M. Giulietti, T.S. Melhem, V. Bitrich \& C. Kameyama (eds.). Flora Fanerogâmica do Estado de São Paulo. FAPESP: Hucitec, São Paulo, v. 2 , pp. 365-374.
Lombardi, J.A. \& Lara, A.C.M. 2003. Hippocrateaceae. In: M.G.L. Wanderley, G.J. Shepherd, A.M. Giulietti, T.S. Melhem, A.M. Giulietti \& M. Kirizawa (eds.). Flora Fanerogâmica do Estado de São Paulo. FAPESP / Rima, São Paulo, v. 3, pp. 109-122.

Lombardi, J.A. \& Temponi, L.G. 1999. A new species of Peritassa Miers (Hippocrateaceae) from Southern Brazil, and notes on two confused species. Novon 9: 221-226.

Mamede, M.C.H. 1992. Malpighiaceae. In: M.M.R.F. Melo F. Barros, S.A.C. Chiea, M.G.L. Wanderley, S.L. JungMendaçolli \& M. Kirizawa (eds). Flora Fanerogâmica da Ilha do Cardoso. Instituto de Botânica, São Paulo, v. 3, pp. 73-87.

Marques, M.C.M. \& Gomes, K. 2002. Polygalaceae. In: M.G.L. Wanderley, G.J. Shepherd, A.M. Giulietti, T.S. Melhem, V. Bitrich \& C. Kameyama (eds.). Flora Fanerogâmica do Estado de São Paulo. FAPESP / Hucitec, São Paulo, v. 2, pp. 229-259.

Melhem, T.S., Giulietti, A.M., Forero, E., Barroso, G.M., Silvestre, M.S.F., Jung, S.L., Makino, H., Fiuza de Melo, M.M.R., Chiea, S.C., Wanderley, M.G.L., Kirizawa, M. \& Muniz, C. 1981. Planejamento para a elaboração da "Flora Fanerogâmica da Reserva do Parque Estadual das Fontes do Ipiranga (São Paulo, Brasil)". Hoehnea 9: 63-74.

Melo, E. 2003. Revisão das espécies do gênero Coccoloba P. Browne nom. cons. (Polygonaceae) do Brasil. Tese de Doutorado, Universidade de São Paulo, São Paulo.

Mohl, H. 1827. Üeber den Bau und des Winden der Ranken und Schlingpflanzen. Classic, VDM Verlag Muller, Leiden.

Palm, L.H. 1827. Üeber das Winden der Pflanzen. C. Richter, Tübingen.

Plumier, R.P.C. 1693. Description des Plantes de l'Amérique, avec leurs figures. L'Imprimerie Royale, Paris.

Putz, F.E. 1984. The natural history of lianas on Barro Colorado Island, Panamá. Ecology 65: 1713-1724.

Putz, F.E. \& Mooney, H.A. 1991. The biology of vines. Cambridge University Press, Cambridge.

Radford, A.E., Dickison, W.C., Massey, J.R. \& Bell, C.R. 1974. Vascular plant systematics. Harper \& Row, New York.

Raunkiaer, C. 1934. The life forms of flowering plants and statistical geography. Claredon Press, Oxford.

Reis, G.L. 2002. Marcgraviaceae. In: M.G.L. Wanderley, G.J. Shepherd, A.M. Giulietti, T.S. Melhem, V. Bitrich \& C. Kameyama (eds.). Flora Fanerogâmica do Estado de São Paulo. FAPESP / Hucitec, São Paulo, v. 2, pp. 181-183.

Reis, L.A.M. 1998. Parque Estadual das Fontes do Ipiranga: utilização e degradação. Monografia de Graduação. Faculdade de Filosofia, Letras e Ciências Humanas, Universidade de São Paulo, São Paulo. 
Reitz, P.R. 1980. Sapindáceas. In: R. Reitz (ed.) Flora Ilustrada Catarinense, parte I. Herbário Barbosa Rodrigues, Itajaí, fasc. SAPI, pp. 3-80.

Richards, P.W. 1996. The tropical rain forest. An ecological study. Cambridge University Press, Cambridge.

Ritter, M.R. \& Miotto, S.T.S. 2005. Taxonomia de Mikania Willd. (Asteraceae) no Rio Grande do Sul, Brasil. Hoehnea 32: 309-359.

Robinson, H. 1999. Generic and Subtribal Classification of American Vernonieae. Smithsonian contributions to botany 89: 78-106.

Sartori, A.L.B. \& Tozzi, A.M.G.A. 1998. As espécies de Machaerium Pers. (Leguminosae - Papilionoideae Dalbergieae) ocorrentes no Estado de São Paulo. Revista Brasileira de Botânica 21: 211-246.

Scalon, V.R., Souza, V.C. \& Rodrigues, R.R. 2002. Valerianaceae. In: M.G.L. Wanderley, G.J. Shepherd, A.M. Giulietti, T.S. Melhem, V. Bitrich \& C. Kameyama (eds.). Flora Fanerogâmica do Estado de São Paulo. FAPESP / Hucitec, São Paulo, v. 2, pp. 349-351.

Schenck, H. 1892. Beiträge zur Biologie und Anatomie der Lianen im Besonderom de in Brasillien einheimischem arten. Beiträge zur Biologie der Lianen. In: A.F.W. Schimper (ed.). Botanishe Mittheilungen aus den Tropen. Gustav Fisher, Jena. v. 4, pp. 2-19.

Simão-Bianchini, R. 1998. Ipomoea L. (Convolvulaceae) no Sudeste do Brasil. Tese de Doutorado, Universidade de São Paulo, São Paulo.

Souza, F.O. 2007. Asteraceae no Parque Estadual da Ilha do Cardoso, Cananéia, SP. Dissertação de Mestrado, Instituto de Botânica, São Paulo.
Souza, F.O. 2008. Flora Fanerogâmica da Ilha do Cardoso (São Paulo, Brasil) Asteraceae. In: M.M.R. Fiuza de Melo, F. Barros, S.A.C. Chiea, M. Kirizawa, S.L. Jung-Mendaçolli \& M.G.L. Wanderley (eds.). Flora Fanerogâmica da Ilha do Cardoso, São Paulo: Instituto de Botânica, v. 13: 29-134.

Souza, J.P. \& Souza, V.C. 2002. Violaceae. In: M.G.L. Wanderley, G.J. Shepherd, A.M. Giulietti, T.S. Melhem, V. Bitrich \& C. Kameyama (eds.). Flora Fanerogâmica do Estado de São Paulo. FAPESP / Hucitec, São Paulo, v. 2, pp. 353-363.

Strufaldi-De-Vuono, Y. 1985. Fitossociologia do Estrato Arbóreo da Floresta da Reserva do Instituto de Botânica (São Paulo, SP). Tese de Doutorado. Universidade de São Paulo, São Paulo.

Udulutsch, R.G. 2004. Composição florística da comunidade de lianas lenhosas em duas formações florestais do Estado de São Paulo. Dissertação de Mestrado, Universidade de São Paulo, Piracicaba.

Whitmore, T.C. 1990. An introduction to tropical rain forests. Clarendon Press, Oxford.

Whittaker, R.H. 1978. Classification of plant communities. Publishers the Hague, Boston.

Xifreda, C.C. \& Kirizawa, M. 2003. Observaciones morfológicas, nomenclaturales y taxonómicas en Dioscorea monadelpha y D. subhastata (Dioscoreaceae). Darwiniana 41: 207-215.

Zappi, D., Aona, L.Y.S. \& Taylor, N. 2007. Cactaceae. In: T.S. Melhem, M.G.L. Wanderley, S.E. Martins, S.L. Jung-Mendaçolli, G.J. Shepherd \& M. Kirizawa (eds.). Flora Fanerogâmica do Estado de São Paulo. Instituto de Botânica, São Paulo, v. 5, pp. 163-193. 